US Army Corps

of Engineers.

Portland District

Prepared for the U.S. Army Corps of Engineers, Portland District,

under a Government Order with the U.S. Department of Energy

Contract DE-AC05-76RL01830

\title{
Seasonal Juvenile Salmonid Presence and Migratory Behavior in the Lower Columbia River
}

\section{FINAL REPORT}
JA Carter
RA Harnish
GA McMichael
ID Welch
BJ Bellgraph

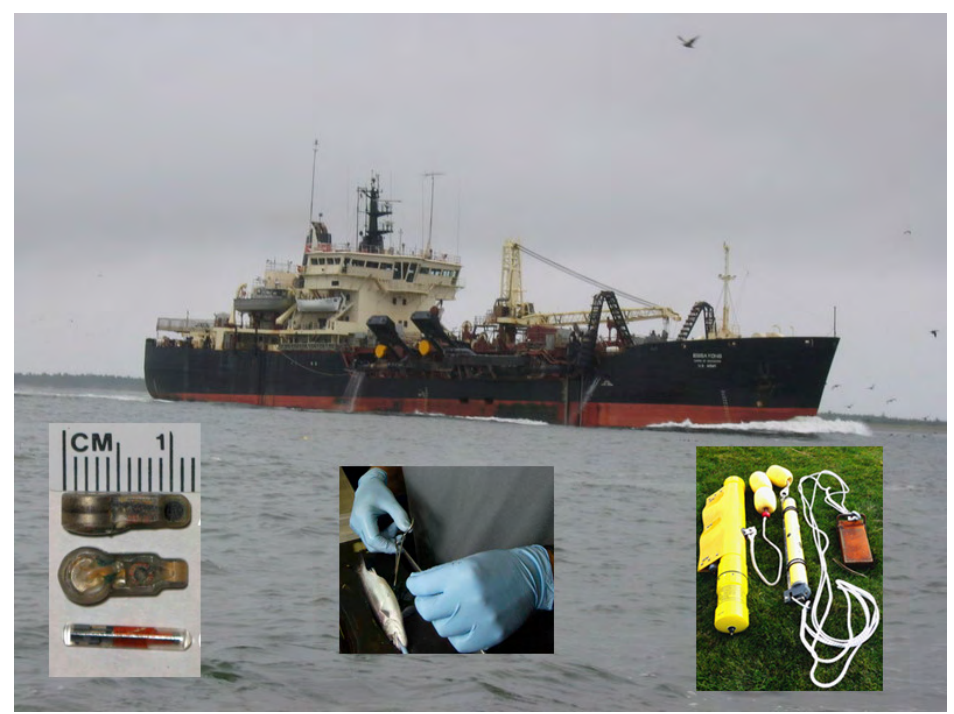

April 2009

April 2009 


\title{
DISCLAIMER
}

This report was prepared as an account of work sponsored by an agency of the United States Government. Neither the United States Government nor any agency thereof, nor Battelle Memorial Institute, nor any of their employees, makes any warranty, express or implied, or assumes any legal liability or responsibility for the accuracy, completeness, or usefulness of any information, apparatus, product, or process disclosed, or represents that its use would not infringe privately owned rights. Reference herein to any specific commercial product, process, or service by trade name, trademark, manufacturer, or otherwise does not necessarily constitute or imply its endorsement, recommendation, or favoring by the United States Government or any agency thereof, or Battelle Memorial Institute. The views and opinions of authors expressed herein do not necessarily state or reflect those of the United States Government or any agency thereof.

\author{
PACIFIC NORTHWEST NATIONAL LABORATORY \\ operated by \\ BATTELLE \\ for the \\ UNITED STATES DEPARTMENT OF ENERGY \\ under Contract DE-AC05-76RL01830 \\ Printed in the United States of America \\ Available to DOE and DOE contractors from the \\ Office of Scientific and Technical Information, \\ P.O. Box 62, Oak Ridge, TN 37831-0062; \\ ph: (865) 576-8401 \\ fax: (865) 576-5728 \\ email: reports@adonis.osti.gov
}

\author{
Available to the public from the National Technical Information Service, \\ U.S. Department of Commerce, 5285 Port Royal Rd., Springfield, VA 22161 \\ ph: (800) 553-6847 \\ fax: (703) 605-6900 \\ email: orders@ntis.fedworld.gov \\ online ordering: http://www.ntis.gov/ordering.htm
}




\title{
Seasonal Juvenile Salmonid Presence and Migratory Behavior in the Lower Columbia River
}

FINAL REPORT

\author{
JA Carter RA Harnish \\ GA McMichael BJ Bellgraph \\ ID Welch
}

April 2009

Prepared for the

U.S. Army Corps of Engineers, Portland District, under a Government Order with the

U.S. Department of Energy

Contract DE-AC05-76RL01830

Pacific Northwest National Laboratory

Richland, Washington 99352 
This report should be cited as follows:

Carter, J. A., G. A. McMichael, I. D. Welch, R. A. Harnish, and B. J. Bellgraph. 2009. Seasonal Juvenile Salmonid Presence and Migratory Behavior in the Lower Columbia River. PNNL-18246, Pacific Northwest National Laboratory, Richland, Washington. 


\section{Summary}

The U.S. Army Corps of Engineers conducts construction and dredging activities in the lower Columbia River and estuary to maintain navigation routes. This area is used by several species of Pacific salmon protected under the Endangered Species Act of 1973. To facilitate planning of proposed channel maintenance projects, the Portland District of the U.S. Army Corps of Engineers contracted the Pacific Northwest National Laboratory to summarize information regarding juvenile anadromous salmonid distribution and behavior in the lower Columbia River and estuary, including existing published information as well as data from 5 years (2004-2008) of acoustic telemetry studies conducted in the Columbia River estuary using the Juvenile Salmon Acoustic Telemetry System.

Juvenile anadromous Pacific salmon rear in and migrate through the Columbia River and estuary between Bonneville Dam and the Pacific Ocean. A large quantity of information has been published on seasonal presence, habitat use, and migratory behavior of Chinook salmon. Some information is available on steelhead. Information on use of the Columbia River estuary by the less abundant anadromous salmonid species (cutthroat and bull trout) and or those species having life histories with limited freshwater rearing and migration (pink and chum salmon) is limited. This is not to say that estuary habitats are not important to the life cycle of these species; instead, it is simply a statement that specific information is lacking or the existing information indicates these species are not known to widely utilize these estuary habitats for extended periods.

Little information exists on use of the Columbia River estuary by pink salmon. Based on published information on this species from other areas, it is likely that pink salmon use of the Columbia River estuary is very limited. Chum salmon are present in the Columbia River estuary following emergence as early as mid-January through mid July, with the peak in abundance between mid April and mid May as they migrate seaward. Hatchery and wild coho salmon use the Columbia River estuary as a migratory route to the Pacific Ocean and also for rearing in some cases. Rearing coho salmon may be in the Columbia River estuary throughout the year, with peak abundance of smolts migrating between April and June. Similar to coho salmon, juvenile Chinook salmon may be found rearing in the Columbia River estuary any time of the year. Stream-type Chinook salmon, which typically rear in higher elevation tributaries for 1 year prior to migrating to sea, are most abundant in the Columbia River estuary between early April and early June. Large numbers of pre-smolt Chinook salmon rear in the Columbia River estuary, and it is likely that many of these are fall Chinook salmon. The fall Chinook salmon migration through the Columbia River estuary typically peaks between May and July. However, there is typically a pulse of subyearling Chinook salmon entering the estuary in March from hatchery releases from Spring Creek National Fish Hatchery upstream of Bonneville Dam. Sockeye salmon typically rear in freshwater lakes for 1 to 3 years prior to migrating to the ocean and primarily use the Columbia River estuary as a migration corridor. The limited information available indicates that sockeye salmon are most abundant in the Columbia River estuary in May. Cutthroat trout may use the Columbia River estuary for seasonal rearing and as a migration corridor, with peak abundance of migratory juveniles between March and May. Steelhead typically rear in freshwater tributary habitats for one to several years prior to seaward migration, although juvenile steelhead may use the estuary for limited rearing. Juvenile steelhead abundance in the Columbia River estuary peaks between late May and mid-June. 
Most anadromous salmonid smolts migrate rapidly through the Columbia River estuary. Migration rates are influenced by river discharge, fish species/run type, distance from the ocean, date, and fish size. In general, smolts pass through the Columbia River estuary more quickly during periods of high discharge and later in their migration season. Larger smolts tend to move more rapidly than their smaller cohorts. Migrating smolts tend to move faster as they approach the ocean, slowing just prior to ocean entry. Smolts that migrate downstream past Bonneville Dam in-river travel more rapidly through the Columbia River estuary than fish that are transported in barges and released downstream of Bonneville Dam. Acoustic telemetry data collected in the Columbia River estuary between 2004 and 2008 indicate that yearling Chinook salmon typically migrated at a rate of about $80 \mathrm{~km} /$ day between Bonneville Dam and Vancouver, Washington. Yearling Chinook salmon migrated slower ( $\sim 0 \mathrm{~km} /$ day) through the section of the Columbia River between Vancouver and the mouth of the Columbia River. Once yearling Chinook salmon committed to leaving the Columbia River, typically during an ebb tide, they migrated rather quickly at rates between 100 and 150 km/day between RKM 8.3 and 2.8. Data collected on arrays of acoustic receivers placed throughout the Columbia River estuary beginning in 2007 indicate that yearling and subyearling Chinook salmon and steelhead travel more slowly in the final $50 \mathrm{~km}$ of the Columbia River than in the previous $200 \mathrm{~km}$, before substantially increasing their travel rates as they exit the river and enter the Pacific Ocean.

When most smolts reached the lower $8 \mathrm{~km}$ of the Columbia River, they exited the river and entered the plume on an ebb tide. Between $76 \%$ and $91 \%$ of the acoustic-tagged yearling Chinook salmon were first detected at RKM 8.3 during an ebb tide. Subyearling Chinook salmon also were more likely to pass RKM 8.3 on an ebb tide, with $84 \%$ to $94 \%$ of those fish passing during ebb tides. Relationships between steelhead passage and tide stage were similar to that of Chinook salmon smolts, with $89 \%$ to $91 \%$ of the acoustic-tagged steelhead passing RKM 8.3 during ebb tide conditions.

Acoustic-tagged salmonid smolts were present in the Columbia River estuary throughout all times of day during their migration seasons, with no clear patterns in diel presence at most acoustic arrays. The one exception may be that more yearling Chinook salmon appeared to pass the Columbia River Bar (RKM 2.8) just after sunrise than at other times of the day.

Most anadromous salmonid smolts appear to migrate seaward in or near the navigation channel. However, information in published reports and from recent acoustic telemetry studies shows that small proportions of the tagged fish were detected using off-channel migration routes. Main channel use in the Bonneville Dam tailrace was pronounced for all tagged species and run types, with a maximum of 3\% of detections in side channels near Reed and Lady islands. Between Vancouver, Washington, and the mouth of the river, side channel use was more common for all groups, with larger proportions of the acoustictagged smolts detected in side channels south of the islands near Cathlamet, Washington, and in Grays Bay.

Most acoustic-tagged yearling and subyearling Chinook salmon passed the acoustic receiver array near East Sand Island (RKM 8.3) on the north (Washington) side of the navigation channel. This was especially pronounced for subyearling Chinook salmon, most of which tended to pass this array close to East Sand Island. With only 2 years of data (2005 and 2008), no clear pattern in cross-channel distribution was observed for acoustic-tagged steelhead on the array near East Sand Island. Migration distribution across the array on the Columbia River Bar (RKM 2.8) tended to be nearer, or in, the navigation channel than it was at RKM 8.3 for yearling and subyearling Chinook salmon and steelhead. 
Limited data on the depth distribution of acoustic-tagged salmonid smolts migrating through the Columbia River estuary in 2007 showed that depth use was highly variable but appeared to be deeper for subyearling Chinook salmon than for yearling Chinook salmon.

Published accounts of the use of plume areas by juvenile salmonids suggest that the Columbia River plume is a food-rich habitat where juvenile salmonids have the opportunity for significant growth as they adjust their physiology to the more saline ocean environment. All species of Pacific salmon that emigrate from the Columbia River estuary utilize the plume to some extent. Several authors have concluded that the structure and conditions within the Columbia River plume may have a pronounced effect on the distribution, growth, and survival of salmon smolts leaving the Columbia River. 


\section{Acknowledgments}

Many people have been instrumental in allowing this project to be completed. We thank Blaine Ebberts, Kim Larson, Steve Helm and Doris KcKillip from the U.S. Army Corps of Engineers, Portland District, for their generous funding and for the opportunity to further explore the data we have collected over the past 5 years. Lynn McComas from NOAA Fisheries kindly allowed us to present depth estimates gathered through his mobile tracking efforts. Dennis Dauble, Evan Arntzen, Joanne Duncan, Greg Gaulke, Kathleen Carter, Andrea Currie, and Mandi Oukrop from Pacific Northwest National Laboratory contributed to the preparation, technical reviews, editing, and formatting of this report. 


\section{Acronyms and Abbreviations}

$\begin{array}{ll}\text { BON } & \text { Bonneville Dam } \\ \text { CC } & \text { corner collector } \\ \text { CH0 } & \text { subyearling Chinook salmon } \\ \text { CH1 } & \text { yearling Chinook salmon } \\ \text { ft } & \text { foot, feet } \\ \text { JDA } & \text { John Day Dam } \\ \text { JSATS } & \text { Juvenile Salmon Acoustic Telemetry System } \\ \text { km } & \text { kilometer(s) } \\ \text { LCR } & \text { lower Columbia River } \\ \text { LGR } & \text { Lower Granite Dam } \\ \text { LGS } & \text { Little Goose Dam } \\ \text { M } & \text { meter(s) } \\ \text { MCR } & \text { mouth of the Columbia River } \\ \text { mm } & \text { millimeter(s) } \\ \text { NAV } & \text { navigation channel } \\ \text { NMFS } & \text { National Marine Fisheries Service } \\ \text { NOAA } & \text { National Oceanic and Atmospheric Administration } \\ \text { PIT } & \text { passive integrated transponder } \\ \text { PNNL } & \text { Pacific Northwest National Laboratory } \\ \text { RKM } & \text { river kilometer(s) } \\ \text { SKA } & \text { Skamania Landing } \\ \text { STL } & \text { steelhead } \\ \text { TDA } & \text { The Dalles Dam } \\ \text { TR } & \text { U.S. Army Corps of Engineers } \\ \text { USACE } & \end{array}$




\section{Contents}

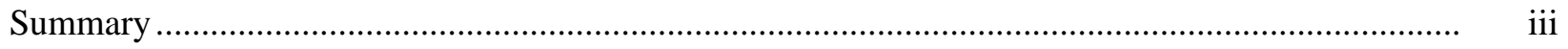

Acknowledgments.............................................................................................................. vii

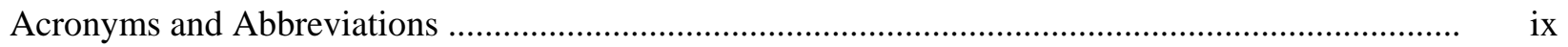

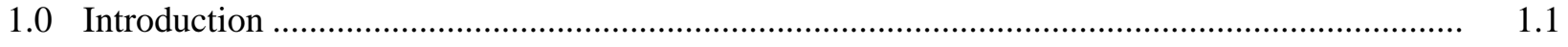

2.0 Literature Review .................................................................................................. 2.1

2.1 Seasonal Presence of Juvenile Anadromous Salmonid Species in the Columbia

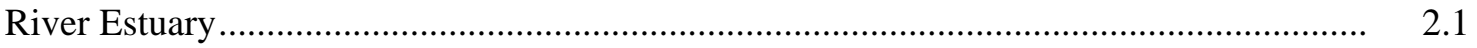

2.1.1 Pink Salmon ........................................................................................................ 2.3

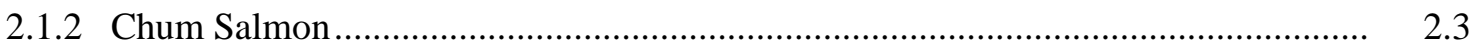

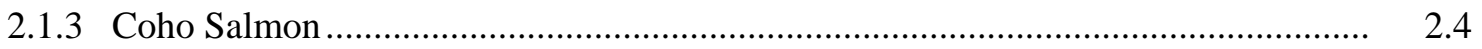

2.1.4 Sockeye Salmon ................................................................................................ 2.4

2.1.5 Coastal Cutthroat Trout .............................................................................. 2.4

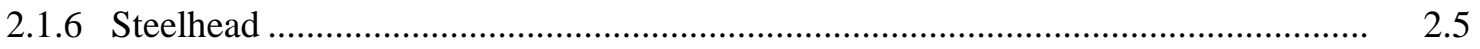

2.1.7 Spring and Fall Chinook Salmon ........................................................................ 2.5

2.2 Habitat Use and Movements of Juvenile Anadromous Salmonids in and through the Columbia River Estuary .......................................................................................... 2.6

2.2.1 Pink Salmon, Chum Salmon, Coho Salmon, and Cutthroat Trout ............................ 2.6

2.2.2 Chinook Salmon and Steelhead........................................................................ 2.8

2.3 Use of the Columbia River Plume by Juvenile Anadromous Salmonids ........................... 2.14

3.0 Juvenile Salmon Acoustic Telemetry System Data Synthesis................................................... 3.1

3.1 Migratory Behavior Characterization Methodology …...................................................... 3.1

3.2 Migratory Behavior Data Summary ........................................................................ 3.8

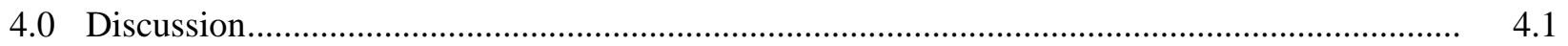

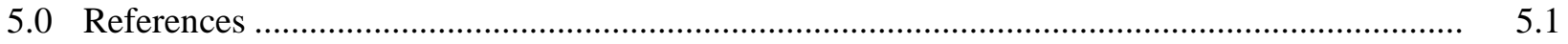

Appendix Latitudes and Longitudes for Receiver Locations and Reference Points......................... A.1 


\section{Figures}

2.1 Salmonid smolt passage at Bonneville Dam, averaged over 1998-2008................................ 2.2

2.2 General trends in presence and abundance of juvenile salmonids in the lower Columbia River estuary, at and downstream from Jones Beach........................................................... 2.2

3.1 JSATS acoustic telemetry receivers in the lower Columbia River in 2004 ............................. 3.4

3.2 JSATS acoustic telemetry receivers in the lower Columbia River in 2005 .............................. 3.4

3.3 JSATS acoustic telemetry receivers in the lower Columbia River in 2006 .............................. 3.5

3.4 JSATS acoustic telemetry receivers in the lower Columbia River in 2007 ............................ 3.5

3.5 JSATS acoustic telemetry receivers in the lower Columbia River in 2008 ............................. 3.6

3.6 Weekly median travel rates of yearling Chinook salmon between acoustic receiving arrays in the Columbia River downstream of Bonneville Dam, 2005 through 2008...

3.7 Weekly median travel rates of subyearling Chinook salmon between acoustic receiving arrays in the Columbia River downstream of Bonneville Dam, 2005 through 2008.

3.8 Weekly median travel rates of steelhead between acoustic receiving arrays in the Columbia River downstream of Bonneville Dam, 2005 and 2008.

3.9 Yearling Chinook salmon released at Bonneville Dam in the tailrace and in the spillway and yearling Chinook salmon released downstream of Lower Granite Dam in 2007 and the effect of release time on presence during each hour of the day

3.10 Hourly distribution of yearling Chinook salmon released at Lower Granite Dam in 2007 at array CR224.0, downstream of Bonneville Dam, by release week.

3.11 Hourly distribution of yearling Chinook salmon released upstream of Bonneville Dam at arrays in the lower Columbia River, 2006-2008

3.12 Hourly distribution of subyearling Chinook salmon released upstream of Bonneville Dam at arrays in the lower Columbia River, 2006-2008.....

3.13 Hourly distribution of steelhead released upstream of Bonneville Dam at arrays in the lower Columbia River, 2008

3.14 Detections of yearling Chinook salmon versus change in tide at CR008.3 .

3.15 Detections of yearling Chinook salmon versus change in tide at CR002.8 .

3.16 Detections of subyearling Chinook salmon versus change in tide at CR008.3

3.17 Detections of subyearling Chinook salmon versus change in tide at CR002.8

3.18 Detections of steelhead versus change in tide at CR008.3.

3.19 Detections of steelhead versus change in tide at CR002.8

3.20 Cross-channel distribution of yearling Chinook salmon at array CR008.3.

3.21 Cross-channel distribution of yearling Chinook salmon at array CR002.8..

3.22 Cross-channel distribution of yearling Chinook salmon at array CR002.8 for periods during which receivers were in the navigation channel.

3.23 Cross-channel distribution of subyearling Chinook salmon at array CR008.3 …..................... 3.27

3.24 Cross-channel distribution of subyearling Chinook salmon at array CR002.8 ......................... 3.27

3.25 Cross-channel distribution of subyearling Chinook salmon at array CR002.8 for periods during which receivers were in the navigation channel..... 
3.26 Cross-channel distribution of steelhead at array CR008.3 ….............................................. 3.28

3.27 Cross-channel distribution of steelhead at array CR002.8 ...................................................... 3.29

3.28 Cross-channel distribution of steelhead at array CR002.8 for periods

during which receivers were in the navigation channel .......................................................... 3.29 


\section{Tables}

2.1 Movement rates and habitat use of chum salmon, coho salmon, and cutthroat trout juveniles in the Columbia River estuary.....

2.2 Movement rates and habitat use of Chinook salmon, steelhead trout, and sockeye salmon juveniles in the Columbia River estuary

3.1 Numbers, date, and size range of releases of acoustic tagged fish, 2004 through 2008

3.2 Description of acoustic receiver arrays, by river section, 2004 through 2008.

3.3 Travel rates for yearling Chinook salmon between each of three sections of the Columbia River downstream of Bonneville Dam, 2005 through 2008

3.4 Travel rates for subyearling Chinook salmon between each of three sections of the Columbia River downstream of Bonneville Dam, 2005 through 2008.

3.5 Travel rates for steelhead between each of three sections of the Columbia River downstream of Bonneville Dam, 2005 through 2008

3.6 Travel rate in kilometers per day for yearling Chinook salmon from first detection at the upstream array to first detection at the downstream array, for three sections in the lower Columbia River between Vancouver and East Sand Island.

3.7 Travel rate in kilometers per day for subyearling Chinook salmon from first detection at the upstream array to first detection at the downstream array, for three sections in the lower Columbia River between Vancouver and East Sand Island.

3.8 Travel rate in kilometers per day for steelhead from first detection at the upstream array to first detection at the downstream array, for three sections in the lower Columbia River between Vancouver and East Sand Island.

3.9 Numbers of fish detected at CR237.0, CR224.0, CR210.0 and, of those, numbers and percentages of fish detected at CR204.0 in the main channel or side channel and at CR193.0 in the main channel or side channel

3.10 Numbers of yearling Chinook salmon and steelhead detected at CR113.0 and, of those, the number and percentage detected at CR097.2 or CR095.0 in 2008

3.11 Numbers of fish detected at CR086.2 and, of those, numbers and percentages of fish detected in the main channel, anywhere in the estuary islands to the south of the main channel, Harrington Point or Grays Bay to the north of the main channel

3.12 Yearling Chinook salmon detected in the main channel or side channel at Tenasillahe Island, by week of detection at CR086.2 in 2007 and 2008.

3.13 Subyearling Chinook salmon detected in the main channel or side channel at Tenasillahe Island, by week of detection at CR086.2 in 2007 and 2008...

3.14 Subyearling

Chinook salmon detected in the main channel or side channel at Tenasillahe Island, by week of detection at CR086.2 in 2008

3.15 Estimated fish depth for yearling and subyearling Chinook salmon tagged with JSATS acoustic transmitters in two sections of the Columbia River downstream of Bonneville Dam 


\subsection{Introduction}

Under the Congressionally authorized Columbia River Channel Operations and Maintenance Program, the U.S. Army Corps of Engineers maintains navigation channels and the structures that influence these channels (e.g., jetties, pile dikes) in the lower Columbia River. Activities required to maintain these channels at sufficient depths to allow for safe passage of deep-draft vessels may influence juvenile salmonids that migrate through or rear in the lower Columbia River estuary and plume (NMFS 2005). These activities were determined to likely have adverse effects on Pacific salmon species protected under the Endangered Species Act of 1973 (ESA). To facilitate preparing Biological Assessments of proposed channel maintenance projects, the Portland District of the U.S. Army Corps of Engineers contracted the Pacific Northwest National Laboratory to consolidate and synthesize available information about the use of the lower Columbia River and estuary by juvenile anadromous salmonids. The information to be synthesized included existing published documents as well as data from 5 years (2004-2008) of acoustic telemetry studies conducted in the Columbia River estuary using the Juvenile Salmon Acoustic Telemetry System. For the purposes of this synthesis, the Columbia River estuary includes the section of the Columbia River from Bonneville Dam at river kilometer (RKM) 235 downstream to the mouth where it enters the Pacific Ocean.

Estuaries are important to the rearing of juvenile salmon and are an integral part of the continuum of habitats that salmon occupy throughout their life cycle (Bottom et al. 2005). All Columbia River anadromous fishes must pass through the estuary en route to the ocean, and some may rear in the estuary for extended periods during the transition from freshwater to saltwater. Historically, all salmonids in the Columbia River system were native fish produced in natural streams. However, artificial propagation now accounts for approximately three-quarters of all returning adult salmonids (Johnson et al. 2003). Hatchery programs, flow regulation, salmon population declines throughout the Columbia basin, as well as wetland habitat losses and increasing water temperatures in the estuary, may have decreased juvenile salmonid use of the estuary in summer and fall compared to historic levels (Rich 1922 as cited in Bottom et al. 2008; Bottom et al. 2008). Columbia River estuary salmon habitat has been dramatically altered by dredging, urbanization, and the construction and operation of hydroelectric dams. Additionally, hydrological barriers, including dikes, levees, and flood control structures such as tide gates, as well as degraded wetland systems with restricted connectivity, have reduced off-channel rearing habitat for salmonids (Bottom et al. 2005; Roegner at al. 2007).

Since 1991, 13 Columbia River salmon stocks have been added to the list of threatened or endangered species under the ESA, which has prompted research focused on the survival and recovery of these stocks. The majority of studies on juvenile salmonid migration patterns in the Columbia River estuary have been conducted on juvenile Chinook salmon (Oncorhynchus tshawytscha), principally migrants from upriver Evolutionary Significant Units such as the Snake River populations. Results from these studies tend to emphasize the estuary primarily as a pathway that is only used briefly as the fish migrate through it to the ocean. However, some life-history strategies involve greater use of the estuary for rearing over extended periods of time. For example, recent findings reported by Marsh et al. (2007), indicated that a large percentage ( $\geq 61 \%$ ) of the returning adult fall Chinook salmon transported and released downstream of Bonneville Dam late in the migration season as juveniles reared in freshwater for an additional winter before entering seawater. A comprehensive work done by Bottom et al. (2005) on habitat use and importance of the estuary to juvenile salmonids, especially those rearing in the estuary, 
also points out that most of the research has been based on migrants from upstream of Bonneville Dam, which are not representative of the populations that rear in the estuary or of naturally produced salmon that have variable life-history strategies.

In this report, we summarize the seasonal salmonid presence and migration patterns in the Columbia River estuary based on information from published studies as well as relevant data from acoustic telemetry studies conducted by NOAA Fisheries and the Pacific Northwest National Laboratory (PNNL) between 2004 and 2008. Recent acoustic telemetry studies, conducted using the Juvenile Salmon Acoustic Telemetry System (JSATS; developed by the Portland District of the U.S. Army Corps of Engineers), provided information on the migratory behavior of juvenile steelhead (O. mykiss) and Chinook salmon in the Columbia River from Bonneville Dam to the Pacific Ocean.

Section 2 provides a summary of information from published literature on the seasonal presence and migratory behavior of juvenile salmonids in the Columbia River estuary and plume. Section 3 presents a detailed synthesis of juvenile Chinook salmon and steelhead migratory behavior based on the use the JSATS between 2004 and 2008. Section 4 provides a discussion of the information summarized in the report as well as information drawn from literature reviews on potential effects of channel maintenance activities to juvenile salmonids rearing in or migrating through the Columbia River estuary and plume. Sources cited are listed in Section 5. The Appendix provides a list of the latitudes and longitudes for the receiver locations and reference points, as well as calculated distances for each receiver location. 


\subsection{Literature Review}

\subsection{Seasonal Presence of Juvenile Anadromous Salmonid Species in the Columbia River Estuary}

Salmonids that use the Columbia River estuary during their life history include steelhead (Oncorhynchus mykiss), chum salmon (O. keta), coho salmon (O. kisutch), sockeye salmon (O. nerka), Chinook salmon (O. tshawytscha), coastal cutthroat trout (O. clarki clarki), and small numbers of pink salmon (O. gorbuscha). The numbers and seasonal extent of salmonids using the estuary during their outmigration has declined during the 20th century (Bottom et al. 2005). Large portions of the salmon populations found in the Columbia River estuary now are released from hatcheries, and the timing of their migrations through the estuary is largely dependent on hatchery release dates and river discharge (Dawley et al. 1986). Variations in migration rates from upstream locations indicate that fish from a common hatchery release group typically do not reach the estuary as one distinct group (Schreck et al. 2005).

Because of the variety of life-history strategies, species, and sizes, juvenile salmonids can be found in the estuary throughout the entire year. Most of the juvenile salmonids migrate through the estuary between March and October, with peaks at various times depending on species and run type. Figure 2.1 summarizes the seasonal timing of the passage of juvenile Chinook salmon, steelhead, coho salmon, and sockeye salmon through the juvenile bypass facility at Bonneville Dam. This graphical summary provides a general indication of when juveniles of each species and run type enter the Columbia River estuary from areas upstream of Bonneville Dam.

Information from studies conducted in the lower $75 \mathrm{~km}$ of the estuary provides seasonal trends in abundance of juvenile anadromous salmonids in the lower Columbia River estuary. Chum salmon presence peaks in early to mid May, followed by coho salmon migrating out during mid to late May, steelhead and sockeye in late May, yearling Chinook salmon in late May and early June, and subyearling Chinook salmon in late June and July (Dawley et al. 1986; McCabe et al. 1986; Roegner et al. 2004; Bottom et al. 2008). Figure 2.2 displays seasonal trends in juvenile salmonid presence throughout the Columbia River estuary, based on studies that specifically investigated migration timing of juvenile salmonids in the Columbia River estuary.

There is little to no information on the specifics of seasonal presence in the Columbia River estuary for juvenile pink salmon, and limited information for sockeye, coho, and chum salmon. Of the overall population of juvenile salmon that use the estuary, these four species comprise a smaller proportion than the Chinook salmon, a more abundant species. Most of the published research has been focused on Chinook salmon and steelhead. Brief descriptions of the juvenile stages of salmonid species life histories, abundance, seasonal presence, and passage through the Columbia River estuary are presented in Sections 2.1.1 through 2.1.7. 


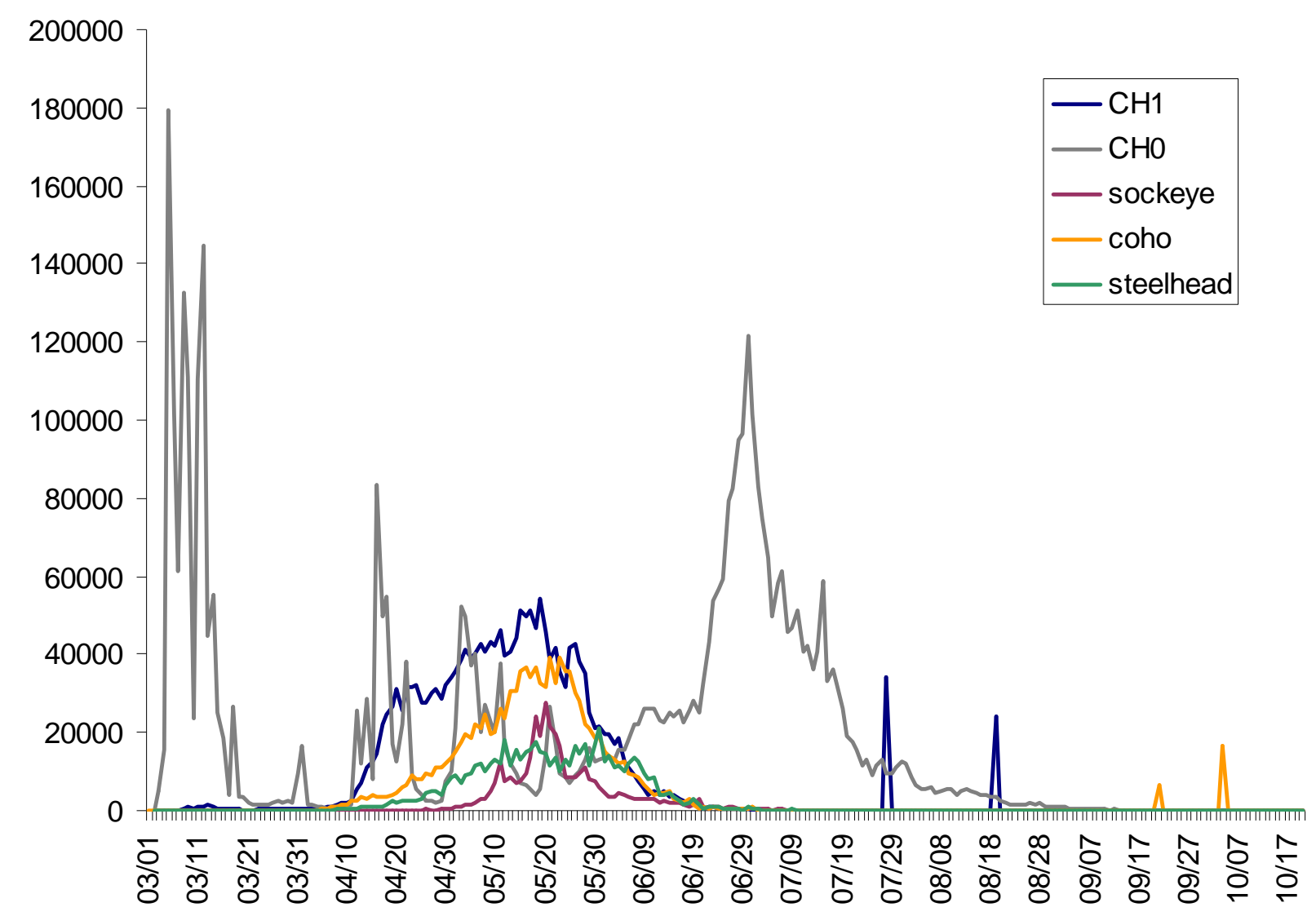

Figure 2.1. Daily salmonid smolt passage at Bonneville Dam, averaged over 1998-2008 (Fish Passage Center data).

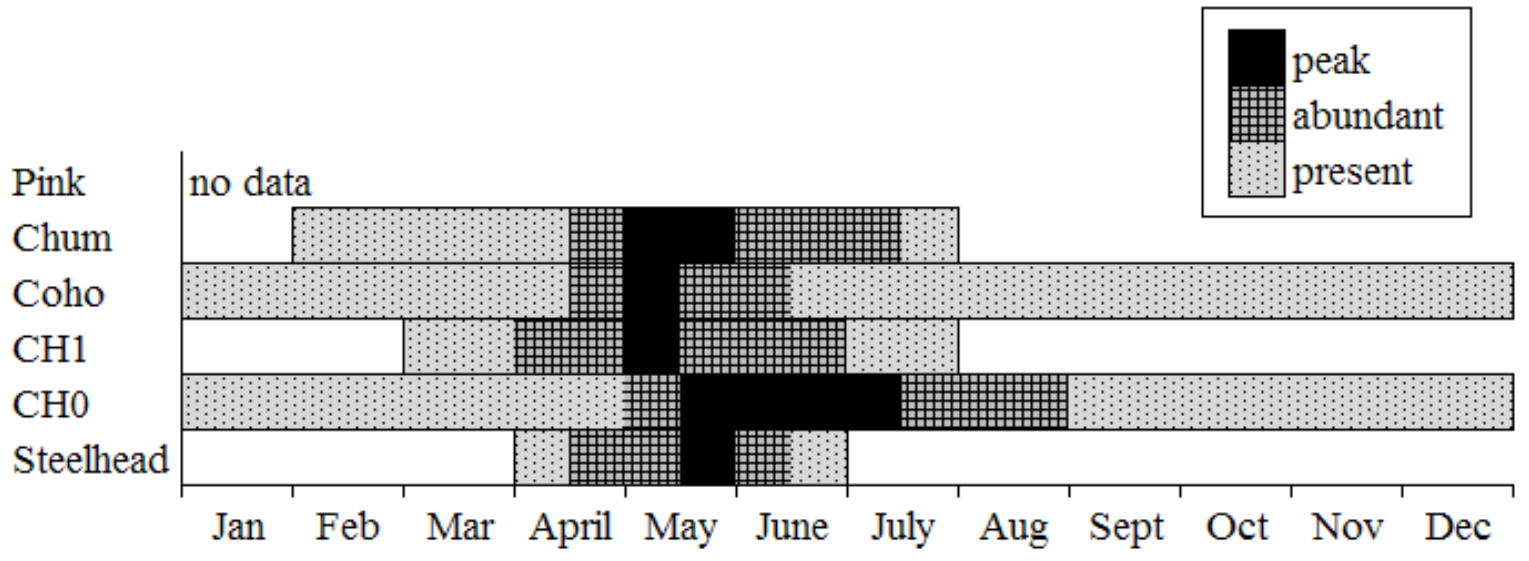

Figure 2.2. General trends in presence and abundance of juvenile salmonids in the lower Columbia River estuary, at and downstream of Jones Beach (RKM 75) (Dawley et al. 1986; McCabe et al. 1986; Roegner et al. 2004; Bottom et al. 2008). 


\subsubsection{Pink Salmon}

The native range of pink salmon in North America is from the Sacramento River in California, to the coast of Alaska and the Mackenzie River, but they are now scarce south of Puget Sound (Hard et al. 1996). Pink salmon spawn in gravel beds in the upper portion of estuaries and lower reaches of rivers (Thorpe 1994). Fry emerge in the spring and move to seawater almost immediately, remaining in the estuary for only as long as it takes them to travel to the ocean (Hard et al. 1996; Thorpe 1994). Information on juvenile pink salmon specific to the Columbia River estuary is scarce. In Puget Sound, Washington, pink salmon fry form schools in shallow water where they feed and grow rapidly during their migration to the ocean (Simenstad et al. 1982). Some studies in the Fraser River indicate pink salmon fry migrate downstream primarily in March and April, although migration can extend into May (Hard et al. 1996).

\subsubsection{Chum Salmon}

Chum salmon tend to spawn farther upstream than pink salmon. Historically, chum salmon were distributed throughout the coastal regions of western Canada and the United States, as far south as Monterey Bay, California. Currently, major spawning populations are found only as far south as Tillamook Bay on the northern Oregon coast (Johnson et al. 1997). Spawning typically occurs in the main stem or in side channels of rivers from just upstream of tidal influence to nearly $100 \mathrm{~km}$ from the sea (Johnson et al. 1997). In the Columbia River, chum salmon are known to spawn in the main stem near Ives Island (RKM 229) and Multnomah Falls (RKM 219), and in tributaries downstream of Bonneville Dam, with the majority of fish spawning on the Washington side of the river (Salo 1991; Johnson et al. 1997; Fish Passage Center 2008).

Unlike pink salmon, chum salmon reside in the estuary during their outmigration in order to feed before beginning their ocean migrations (Thorpe 1994; Johnson et al. 1997). Fry typically emerge at night and promptly begin migrating downstream to the estuary (Salo 1991). The timing of outmigration is usually associated with increasing day length, warming of estuarine waters, and high densities of plankton (Salo 1991; Johnson et al. 1997). Therefore, juvenile chum salmon in southern areas, such as those in Washington and southern British Columbia, tend to migrate earlier (late January through May) than fry in northern British Columbia and southeastern Alaska (April to June) (Johnson et al. 1997). Migrations of chum fry into Grays Harbor in Washington were reported to peak in late April (Brix 1981 cited in Salo 1991). In the Fraser River, chum fry moved in and out of salt-marsh channels with the tides where they remained for an average of 11 days (Levy and Northcote 1982). Studies in the Nanaimo and Nitinat estuaries in British Columbia (Healy 1982), Puget Sound (Simenstad et al. 1982), and Yaquina Bay, Oregon (Myers and Horton 1982), found chum salmon present in those estuarine environments for two to three months, although individual residence times were not determined. Residence times also changed seasonally in Puget Sound where chum fry remained for about one week in February and March, but remained for up to 1 month in April to June (Simenstad et al. 1982). Beach seine samples in the lower Columbia River estuary found chum salmon present from February through May, with peak numbers occurring in April (Roegner at al. 2004). 


\subsubsection{Coho Salmon}

Coho salmon tend to spawn even farther upriver than pink or chum salmon and are found in many tributaries along the Washington side of the Columbia River (Sandercock 1991). The vast majority of coho fry remain feeding and growing in the freshwater river environment for at least 1 year after emergence (Sandercock 1991; Thorpe 1994). Once they begin their seaward migration, they generally do not delay in the estuary but pass through directly to the ocean (Thorpe 1994). In the Columbia River estuary, juvenile coho enter the upper estuary between late April and early June, and their numbers peak between May 6 and 17 (Durkin 1982). In Yaquina Bay, Myers and Horton (1982) reported coho salmon present for over two to three months, but individual residence times were only four to nine days. Beach seine and purse seine sampling at Jones Beach (RKM 75) from 1966 through 1972 and 1977 through 1983 caught juvenile coho between mid-April and late May, with the peak outmigration occurring in May (Dawley et al. 1986). Few juvenile coho were caught in beach seining in the lower part of the estuary, but almost all were captured in May (Roegner et al. 2004).

\subsubsection{Sockeye Salmon}

Although sockeye salmon have a range of life-history strategies, juvenile anadromous sockeye salmon typically rear in lakes for 1 to 3 years after emergence (Burgner 1991; Gustafson et al. 1997). However, some Alaskan populations use stream areas and migrate to sea soon after emergence (Burgner 1991; Thorpe 1994). The Columbia River system is home to the southernmost sockeye runs in North America where juveniles begin their seaward migrations in mid to late May (Gustafson et al 1997). Within the Columbia River basin in Washington, historical populations of sockeye salmon existed in the Yakima, Wenatchee, and Okanogan rivers (Gustafson et al. 1997). Smolt migration typically occurs between sunset and sunrise, beginning in late April and extending through early July, with southern stocks migrating earliest (Burgner 1991; Gustafson et al. 1997). In the Columbia River estuary, sockeye were captured in seine nets in the late 1960s and late 1970s, from mid-April to late June, with peak numbers in late May (Dawley et al. 1986).

\subsubsection{Coastal Cutthroat Trout}

Coastal cutthroat trout have a variety of life-history strategies, even within the same watershed where fish may remain in freshwater or become anadromous (Johnson et al. 2008). The anadromous and freshwater forms exist along the coast from the Eel River in Northern California to the Kenai Peninsula of Alaska (Quinn 2005). Coastal cutthroat trout in the Columbia River that exhibit anadromy do so at age two or three, migrating as juveniles in the spring. The proportion that leaves in the spring versus the proportion that remains in freshwater for residency or later migration is unknown (Trotter 1989; Johnson et al. 2008; Zydlewski et al. 2008). PIT-tagged coastal cutthroat trout caught by electrofishing were monitored from three tributaries-Abernathy Creek (RKM 87), Chinook River (RKM 6), and Gee Creek (RKM 140) - in the lower Columbia River from 2001 to 2004. Antenna arrays and smolt traps were used to detect smolts as they migrated out of these tributaries. Peak movement out of Abernathy Creek occurred in April and May, out of the Chinook River between March and May, and from Gee Creek between February and April (Johnson et al. 2008). Although not extensively studied, it is believed that cutthroat trout generally make extensive use of the river mainstem and estuary habitats with minimal use offshore (Zydlewski et al. 2008). However, some radio-tagged and acoustic-tagged cutthroat trout exhibited directed seaward movements and exited the river mouth into the plume (Zydlewski et al. 2008). 


\subsubsection{Steelhead}

Steelhead are the anadromous form of rainbow trout and are widely distributed between Malibu Creek, California, and Bristol Bay, Alaska (Quinn 2005). Steelhead differ from the other Pacific salmon species; they spawn in the spring and may survive, migrate seaward following spawning (referred to as kelt), and return to spawn again (Quinn 2005). Steelhead fry emerge in late spring or early summer, and juveniles typically remain in freshwater for 1 to 3 years and then migrate out in the spring (Quinn 2005). In the Columbia River estuary, at Jones Beach, peak catches of steelhead in beach and purse seines were generally in the latter part of May (Dawley et al. 1986).

\subsubsection{Spring and Fall Chinook Salmon}

Chinook salmon are the most abundant species of salmonid to occur in the Columbia River estuary (Figure 2.1) and are also the most widely studied. Chinook salmon exhibit a range of life-history strategies that generally fall into one of two categories-stream-type or ocean-type. Chinook salmon that exhibit the stream-type life-history strategy spend one or more years as fry or parr in freshwater before migrating to the ocean and returning to their natal river in spring or summer (Healy 1991). These fish are referred to as spring Chinook. Ocean-type Chinook salmon typically migrate to the ocean during their first year of life and return to spawn in the fall (Healy 1991). These fish are referred to as fall Chinook salmon. Fall Chinook salmon comprise the majority of this species that inhabit the Columbia River. Hatchery programs, flow regulation, population losses throughout the basin, as well as wetland habitat losses and increasing water temperatures in the estuary, may have decreased the proportion of Chinook salmon using the estuary in summer and fall compared to historical levels documented in early studies prior to 1920 (Bottom et al. 2008).

Juvenile stream-type, or spring, Chinook salmon enter the estuary around April (Fish Passage Center data; Figure 2.1) after spending a year in freshwater and thus are referred to as yearling Chinook salmon. At Jones Beach (RKM 75), catches of juvenile yearling Chinook salmon declined rapidly in June and early July, after which almost none were captured through to the end of the year (Dawley et al. 1986). The peak catches of yearling Chinook salmon generally occurred in late May (Dawley et al. 1986).

Juvenile fall Chinook salmon typically enter the estuary in the spring and summer after a shorter development period in production areas and are thus referred to as subyearling Chinook salmon. However, there is a large pulse of juvenile fall ("Tule") Chinook salmon that are released as subyearlings from the Spring Creek National Fish Hatchery (RKM 269) upstream of Bonneville Dam, typically in March (Figure 2.1). Juvenile subyearling Chinook salmon are smaller than their yearling counterparts and tend to use the estuary as juvenile rearing habitat to a much greater degree than other juvenile salmonids (Thorpe 1994). Salt marshes and tidal channels are important habitats as a source of food and shelter for subyearling Chinook salmon rearing in the estuary (Healy 1982; Bottom et al. 2005). Chinook salmon rearing in Yaquina Bay were present from April to November, with peak abundance in mid-July (Myers and Horton 1982). They initially inhabited the upper estuary and nearshore areas and, as they grew, moved downstream to the lower estuary and into deeper waters (Myers and Horton 1982).

Beach seine sampling at Jones Beach over an entire year indicated that $80 \%$ of the juvenile fall Chinook salmon entered the estuary between late April and early September (Dawley et al. 1986). More recent studies corroborate this pattern, showing Chinook salmon are found in the estuary year round, with 
the vast majority present between May and September (McCabe et al. 1986; Roegner et al. 2004; Bottom et al. 2008). Generally there is a peak in abundance in May and June, followed by a decline later in June, then a second (and usually greater) peak in late July (Dawley et al. 1986).

McCabe et al. (1986) sampled various areas in the estuary with bottom trawls, purse seines, beach seines, and trap nets in pelagic and intertidal habitat upstream and downstream of Tongue Point (RKM 29). In the pelagic habitat of the upper estuary (upstream of Tongue Point) in 1980, subyearling Chinook salmon showed a bimodal peak in abundance (May and July), whereas in the lower estuary their abundance peaked in June in pelagic habitats (McCabe et al. 1986). In the intertidal habitat, abundance of subyearling Chinook salmon peaked in June in both the upper and lower estuary.

Larger subyearling Chinook salmon from upstream sources, used in tagging and mark recovery studies, tend to remain within the Columbia River estuary for a relatively short period of time (Dawley et al. 1986). Late migrant (or late transported) subyearling Chinook salmon may utilize the Columbia River estuary for extended rearing (Marsh et al. 2007). These fish likely reside in the lower Columbia River and estuary over their first winter, migrating seaward in their second year of life. Very little information is available for this juvenile subyearling Chinook salmon life-history strategy in the lower Columbia River. However, there is some documentation of this extended rearing strategy for subyearling Chinook salmon in the Snake River reservoirs (Connor et al. 2002, 2005; Cook et al. 2007; McMichael et al. 2008).

\subsection{Habitat Use and Movements of Juvenile Anadromous Salmonids in and through the Columbia River Estuary}

\subsubsection{Pink Salmon, Chum Salmon, Coho Salmon, and Cutthroat Trout}

Juvenile chum salmon, coho salmon, and cutthroat trout primarily use backwater and channel margin habitats during the pre-smolt and smolt life stages in the Columbia River estuary (Table 2.1). However, cutthroat trout smolts have been sampled from mid-channel habitats (Johnsen and Sims 1973). Cutthroat trout tagged with both radio and acoustic tags displayed directed downstream movement toward the ocean and traveled from Mill, Abernathy, and Germany creeks to the mouth of the Columbia River in 4.3 to 6.6 days, with many individuals traveling the distance in 1-2 days (Zydlewski et al. 2008). Migrating juvenile cutthroat trout were typically observed traveling near shore, although several juveniles crossed and migrated within the navigation channel for several hours (Zydlewski et al. 2008).

Pink salmon and bull trout/dolly varden (Salvelinus confluentus/S. malma), although more rare than the aforementioned species, have been cited as using the Columbia River estuary (Johnson et al. 2003). However, little information is available in the literature to determine the estuarine habitat use of these species.

Migrating coho salmon smolts moved downstream at a rate varying from 2 to $59 \mathrm{~km} /$ day (Table 2.1, Dawley et al. 1986). Radio-tagged coho salmon in the Grays Harbor estuary were also influenced by flow, with periods of passive downstream movement in strong currents and periods of holding in lowvelocity habitats (Bottom et al. 2005). Nearshore and mid-river catches of coho indicated a fairly uniform migration throughout the day period (Ledgerwood et al. 1991). Maximum catches of coho in beach and 
purse seines were made during the day between 0600 and 2000 hours (Dawley et al. 1986). Most coho salmon smolts spend midmorning to late afternoon near shore and are found in mid-river areas at dawn and dusk (Pearson et al. 2005).

Table 2.1. Movement rates and habitat use of chum salmon, coho salmon, and cutthroat trout juveniles in the Columbia River estuary. Empty cells indicate information was not available in the cited reference. Migration rates are not applicable (i.e., N/A) to the pre-smolt life stage. The estuary was grouped into three river sections from Bonneville Dam to Vancouver, Washington (BON-VAN; RKM 234 to 170), the lower Columbia River (LCR; RKM 170 to 4.8 ), and the mouth of the Columbia river (MCR; RKM 4.8 to -4.8).

\begin{tabular}{|c|c|c|c|c|c|c|c|c|}
\hline Species & $\begin{array}{l}\text { Run } \\
\text { type }\end{array}$ & $\begin{array}{l}\text { River } \\
\text { section }\end{array}$ & RKM & $\begin{array}{l}\text { Length } \\
(\mathrm{mm})\end{array}$ & $\begin{array}{l}\text { Movement } \\
\text { rate (mean } \\
\mathrm{km} / \text { day) }\end{array}$ & Habitat use & $\begin{array}{c}\text { Sampling } \\
\text { method(s) }\end{array}$ & Citation \\
\hline \multicolumn{9}{|c|}{ Pre-Smolts } \\
\hline \multirow{3}{*}{ Chum } & Fall & LCR & & $\sim 40$ & N/A & $\begin{array}{l}\text { Tidal freshwater } \\
\text { swamp }\end{array}$ & $\mathrm{TN}$ & $\begin{array}{l}\text { Roegner et al. } \\
2007\end{array}$ \\
\hline & Fall & MCR & $\sim 1$ & $<45$ & N/A & Brackish marsh & PLS1, PLS2 & $\begin{array}{c}\text { Roegner et al. } \\
2007,2008\end{array}$ \\
\hline & Fall & MCR & & $>30$ & N/A & $\begin{array}{l}\text { Tidal freshwater } \\
\text { swamp }\end{array}$ & $\mathrm{TN}$ & $\begin{array}{l}\text { Roegner et al. } \\
2008\end{array}$ \\
\hline \multirow{5}{*}{ Coho } & & LCR & & 46 & N/A & $\begin{array}{l}\text { Tidal freshwater } \\
\text { swamp }\end{array}$ & BS & $\begin{array}{c}\text { Roegner et al. } \\
2007\end{array}$ \\
\hline & & LCR & & $\sim 40$ & N/A & $\begin{array}{l}\text { Tidal freshwater } \\
\text { swamp }\end{array}$ & $\mathrm{TN}$ & $\begin{array}{c}\text { Roegner et al. } \\
2007\end{array}$ \\
\hline & & MCR & $\sim 1$ & $<45$ & N/A & Brackish marsh & PLS1, PLS2 & $\begin{array}{c}\text { Roegner et al. } \\
\text { 2007, } 2008\end{array}$ \\
\hline & & MCR & $\sim 1$ & & N/A & Brackish marsh & PLS1, PLS2 & $\begin{array}{c}\text { Roegner et al. } \\
2007\end{array}$ \\
\hline & & MCR & & $>30$ & N/A & $\begin{array}{l}\text { Tidal freshwater } \\
\text { swamp }\end{array}$ & $\mathrm{TN}$ & $\begin{array}{l}\text { Roegner et al. } \\
2008\end{array}$ \\
\hline \multirow[t]{2}{*}{ Cutthroat } & & $\begin{array}{l}\text { BON-VAN } \\
\& \text { LCR }\end{array}$ & $47-233$ & & N/A & Channel margin & & $\begin{array}{c}\text { Pauley et al. } \\
1986\end{array}$ \\
\hline & \multicolumn{8}{|c|}{ Smolts } \\
\hline \multirow{3}{*}{ Chum } & Fall & LCR & 40 & & & Side channels & $\mathrm{TN}$ & $\begin{array}{l}\text { Roegner et al. } \\
2004\end{array}$ \\
\hline & & LCR & 75 & & N/A & Channel margin & BS & $\begin{array}{c}\text { Hinton and } \\
\text { Emmet } 1994\end{array}$ \\
\hline & & $\begin{array}{l}\text { BON-VAN } \\
\text { \& LCR }\end{array}$ & $82-156$ & $\sim 40$ & N/A & Channel margin & BS & $\begin{array}{l}\text { Pearson et al. } \\
2006\end{array}$ \\
\hline \multirow{4}{*}{ Coho } & & $\begin{array}{l}\text { BON-VAN } \\
\text { \& LCR }\end{array}$ & $233-75$ & 124-137 & $3.5-26.4$ & Channel margin & BS, PS & $\begin{array}{c}\text { Dawley et al. } \\
1986\end{array}$ \\
\hline & & LCR & 75-16 & 140-190 & $12-59$ & Channel margin & BS, PS & $\begin{array}{c}\text { Dawley et al. } \\
1986\end{array}$ \\
\hline & & LCR & 75 & & & $\begin{array}{l}\text { Channel margin } \\
\text { and mid-channel }\end{array}$ & BS, PS & $\begin{array}{l}\text { Ledgerwood } \\
\text { et al. } 1991\end{array}$ \\
\hline & & $\begin{array}{l}\text { LCR \& } \\
\text { MCR }\end{array}$ & $75-0$ & 140-190 & $2-44$ & Channel margin & BS, PS & $\begin{array}{c}\text { Dawley et al. } \\
1986\end{array}$ \\
\hline \multirow{3}{*}{ Cutthroat } & & LCR & $>46$ & & & Mid-channel & PS & $\begin{array}{c}\text { Johnsen and } \\
\text { Sims } 1973\end{array}$ \\
\hline & & LCR & 96 & & N/A & Channel margin & BS & $\begin{array}{l}\text { Hinton and } \\
\text { Emmet } 1994\end{array}$ \\
\hline & & $\begin{array}{l}\text { BON-VAN } \\
\text { \& LCR }\end{array}$ & 82-156 & & N/A & Channel margin & BS & $\begin{array}{c}\text { Pearson et al. } \\
2006\end{array}$ \\
\hline
\end{tabular}




\subsubsection{Chinook Salmon and Steelhead}

Habitat use information for Chinook salmon, steelhead, and sockeye salmon pre-smolts in the Columbia River estuary is scarce in the literature. Chinook salmon pre-smolts used backwater habitats for rearing in the lower Columbia River estuary and near the Columbia River mouth; however, information on steelhead and sockeye salmon was unavailable (Table 2.2). Pre-smolt steelhead are likely very rare and possibly nonexistent in the Columbia River estuary because adults typically spawn in high elevation, cold-water tributaries. Similarly, sockeye salmon pre-smolts are most likely confined to highelevation lakes where breeding and rearing occur. Therefore, juveniles use the estuary only during outmigration. The run-type of Chinook salmon pre-smolts was not stated in the literature and was classified as unknown. However, it is likely that most pre-smolts were fall run-type because the life history of spring- and summer-type Chinook salmon typically occurs farther upstream where those juveniles rear in tributaries for a year prior to seaward migration.

All smolts were generally found in the navigation channel of the Columbia River estuary but have also been reported in channel margin habitats (Table 2.2). Information on the location of smolts within the cross section of the river is likely most reliable because the entire cross section was interrogated (Carlson et al. 2001; Ledgerwood et al. 2004; Schreck et al. 2005; PNNL, unpublished data).

In general, the larger juvenile salmonids tended to occupy deeper, offshore channel areas of the estuary, while the smaller fish tended to be found more frequently in the shallower nearshore areas. Juvenile Chinook and chum salmon less than 50-60 mm long were found primarily in shallow water (e.g., $<1 \mathrm{~m}$ ), fish 60-100 mm long were found in slightly deeper habitats (shoals, distributary channels), and fish greater than $100 \mathrm{~mm}$ long were found in deep- and shallow-water habitats (Carlson et al. 2001; Bottom et al. 2005).

In capture studies with beach and purse seines, yearling Chinook and coho salmon and steelhead were most abundant in the offshore channel areas in purse seine samples, whereas the smaller fish, especially subyearling Chinook salmon, were usually found near the beaches (Johnsen and Sims 1973; Dawley et al. 1986; McCabe et al. 1986; Ledgerwood et al. 1991). Most were located within depths of $3 \mathrm{~m}$ or less (Carlson et al. 2001). However, Bottom et al. (2005) noted that yearling Chinook salmon found in the estuary prior to June could also be found along the shoreline.

The main navigation channel was used by $99 \%$ of the acoustic-tagged yearling Chinook salmon detected at Jim Crow Point (RKM 47) during their seaward migration, and only 1\% used a smaller channel on the southern side of the river (Schreck et al. 2005). At this same location, 95\% of the juvenile steelhead were detected in the navigation channel, and 5\% were detected in the smaller channel on the south side (Schreck et al. 2005) (Table 2.2).

Downstream from Jim Crow Point, the majority of the yearling Chinook (66\%) remained in the navigation channel, whereas 28\% migrated north of Rice Island, and 6\% utilized smaller side-channel habitats (Schreck et al. 2005). For steelhead studied in 2003, the majority of fish remained in the navigation channel (76\%), only $8 \%$ used the channel north of Rice Island, and $16 \%$ used the smaller side channels (Schreck et al. 2005) (Table 2.2).

Although salmonid smolts were also sampled in channel margin habitats, sampling was confined primarily to these areas due to sampling gear type; thus, the sampling is likely a biased view of where 
most smolts migrated (Dawley et al. 1986). Smolts were also detected in side channels and bay habitats (i.e., Grays Bay) in the Columbia River estuary, albeit less commonly. Roegner et al. (2007) sampled fish using beach seines at nearshore areas in Young's Bay and the Grays River mouth for a habitat restoration study. Few salmonids were caught at the Young's Bay sites, and of those, all Chinook and coho salmon were less than $70 \mathrm{~mm}$ long. The Grays River system has both natural and hatchery-produced salmonids, and chum salmon dominated the salmonid catch, followed by coho and a low number of Chinook salmon. The majority of these salmonids sampled were fry less than $60 \mathrm{~mm}$, although fingerling Chinook and coho and yearling coho salmon were also present (Roegner et al. 2007).

There is little specific information in the literature about the depths at which the different types of juvenile salmonids travel through the estuary. Trawl samples from the channel off Tongue Point, Clatsop Spit, and Jones Beach in 1966 showed that more than 95\% of all juvenile fall Chinook salmon were within $3 \mathrm{~m}$ of the surface (Dawley et al. 1986). Fish detected by hydroacoustics in the channel and channel margins were significantly higher in the water column during the day than during the evening and night, whereas most fish closer to shore were detected within $2 \mathrm{~m}$ of the bottom during both day and night (Carlson et al. 2001). Both laboratory and field studies have shown that juvenile salmonids prefer to occupy surface waters but will move up or down in the water column in response to adverse condition changes such as temperature and oxygen levels (Birtwell and Kruzynksi 1989).

Avian predation studies have shown a greater susceptibility to terns by hatchery steelhead and yearling Chinook, indicating they have a greater tendency to reside near the surface of the water (Collis et al. 2001; Roby et al. 2003).

Migration rates through the lower Columbia River and estuary were highly variable among salmonid species and studies (1 to $170 \mathrm{~km} /$ day; Table 2.2). Variability is likely due to several factors that affect migration rate, including fish origin, fish size (Dawley et al. 1986), run-type (Schiewe et al. 1989), Columbia River discharge (Schreck et al. 2005; Ledgerwood et al. 2004), tidal cycle (Schreck and Stahl 1998), and diel period (Dawley et al. 1986; Ledgerwood et al. 1991; Carlson et al. 2001).

Radio-tagged spring and summer Chinook salmon released downstream of Bonneville Dam (RKM 235) migrated to RKM 89 in 1 to 6 days at a mean rate of $81.6 \mathrm{~km} /$ day (Schreck et al. 2005). Acoustic-tagged spring and summer Chinook salmon migrated through the estuary from Jim Crow Point (RKM 47) to the ocean in 13 to $111 \mathrm{~h}$ (median $27 \mathrm{~h}$ ) (Schreck et al. 2005). River discharge was highly correlated to the migration rate at which radio-tagged yearling Chinook and PIT-tagged yearling Chinook and steelhead migrated from Bonneville Dam to Jones Beach (Ledgerwood et al. 2004; Schreck et al. 2005).

Ledgerwood et al. (2004) compared travel times and migration rates of fish from Lower Granite Dam that migrated in-river to those that were transported in barges and released at Skamania Landing, just downstream from Bonneville Dam. The median travel time for in-river migrants from the tailrace of Lower Granite Dam to Jones Beach was 17 days for both yearling Chinook salmon and steelhead in 2000 (a high water year) and nearly twice as long in 2001 (a low water year), when the median travel time was 33 days for Chinook salmon and 30 days for steelhead (Ledgerwood et al. 2004).

Travel time for in-river migrants from detection at Bonneville Dam to detection in the estuary was similar, with median travel times of 1.7 days for both species in 2000 and 2.3 and 2.5 days for yearling Chinook salmon and steelhead, respectively, in 2001. The transported fish exhibited slightly slower 
travel times of 2.0 days for Chinook salmon and 1.6 days for steelhead in 2000, and 2.9 and 2.3 days, respectively, in 2001. Mean travel rates in 2000 were $73 \mathrm{~km} /$ day and $88 \mathrm{~km} /$ day for transported Chinook salmon and steelhead, respectively, and $91 \mathrm{~km} /$ day and $93 \mathrm{~km} /$ day for the in-river migrants. In 2001, mean travel rates of transported and in-river migrant fish were 61 and $68 \mathrm{~km} /$ day for yearling Chinook salmon and 67 and $66 \mathrm{~km} /$ day for steelhead (Ledgerwood et al. 2004).

Recovery of hatchery-origin freeze-branded fish in both beach and purse seines at Clatsop Spit (RKM 7) demonstrated a migration time of 6 days or less from Jones Beach (RKM 75), suggesting minimal rearing occurred in the lower $75 \mathrm{~km}$ of the estuary (Dawley et al. 1986). This method, however, may not accurately represent estuarine residency because the timing describes group movement, composed of hundreds of thousands of similarly marked hatchery-origin fish (Bottom et al. 2005).

Table 2.2. Movement rates and habitat use of Chinook salmon, steelhead trout, and sockeye salmon juveniles in the Columbia River estuary. Empty cells indicate information was not available in citations. Migration rates were not applicable (i.e., N/A) to the pre-smolt life stage. The estuary river sections are from Bonneville Dam to Vancouver, Washington (BON-VAN; RKM 234 to 170), the lower Columbia River (LCR; RKM 170 to 4.8), and the mouth of the Columbia river (MCR; RKM 4.8 to -4.8).

\begin{tabular}{|c|c|c|c|c|c|c|c|c|c|}
\hline $\begin{array}{l}\text { Life } \\
\text { stage }\end{array}$ & Species & Run type & $\begin{array}{c}\text { River } \\
\text { section }\end{array}$ & RKM & $\begin{array}{l}\text { Length } \\
\text { (mm) }\end{array}$ & $\begin{array}{l}\text { Movement } \\
\text { rate } \\
(\mathrm{km} / \text { day })^{(\mathrm{a})}\end{array}$ & $\begin{array}{l}\text { Habitat } \\
\text { use }^{(\mathrm{b})}\end{array}$ & 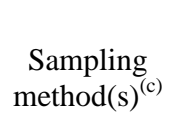 & Citation \\
\hline \multirow{14}{*}{ 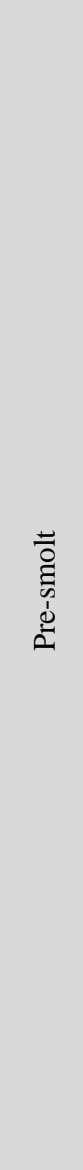 } & \multirow{14}{*}{ 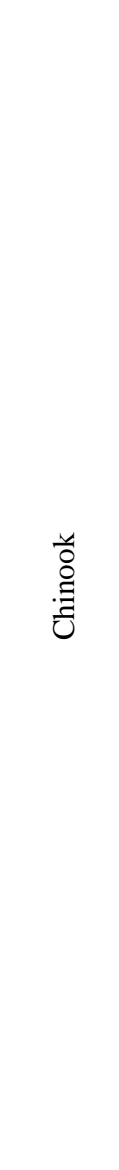 } & Unknown & LCR & & $\sim 40$ & N/A & $\begin{array}{c}\text { Tidal } \\
\text { freshwater } \\
\text { swamp }\end{array}$ & $\mathrm{TN}$ & $\begin{array}{l}\text { Roegner et } \\
\text { al. } 2007\end{array}$ \\
\hline & & Unknown & LCR & & $<50$ & N/A & Marsh & $\mathrm{TN}$ & $\begin{array}{l}\text { Roegner et } \\
\text { al. } 2004\end{array}$ \\
\hline & & Unknown & LCR & 9.9-12.1 & & N/A & & BS & $\begin{array}{c}\text { Bottom et al. } \\
2008\end{array}$ \\
\hline & & Unknown & LCR & $19.8-22.0$ & & N/A & & BS & $\begin{array}{c}\text { Bottom et al } \\
2008\end{array}$ \\
\hline & & Unknown & LCR & 79.2-83.6 & & N/A & & BS & $\begin{array}{c}\text { Bottom et al } \\
2008\end{array}$ \\
\hline & & Unknown & LCR & $35-53$ & $\sim 40$ & N/A & $\begin{array}{c}\text { Tidal } \\
\text { wetlands }\end{array}$ & FN & $\begin{array}{c}\text { Bottom et al } \\
2008\end{array}$ \\
\hline & & Unknown & LCR & 19 & $31-50$ & N/A & $\begin{array}{l}\text { Tidal- } \\
\text { riverine }\end{array}$ & BS & $\begin{array}{c}\text { Bottom et al. } \\
2005\end{array}$ \\
\hline & & Unknown & LCR & 7 & $31-50$ & N/A & $\begin{array}{l}\text { Tidal- } \\
\text { riverine }\end{array}$ & BS & $\begin{array}{c}\text { Bottom et al } \\
2005\end{array}$ \\
\hline & & Unknown & LCR & 19 & $31-50$ & N/A & & BS & Rich 1922 \\
\hline & & Unknown & LCR & 7 & $31-50$ & N/A & & BS & Rich 1922 \\
\hline & & Unknown & LCR & & $31-50$ & N/A & & BS & Rich 1922 \\
\hline & & Unknown & LCR & & $31-45$ & N/A & & BS & Rich 1922 \\
\hline & & Unknown & MCR & $\sim 1$ & $<45$ & N/A & $\begin{array}{c}\text { Brackish } \\
\text { marsh }\end{array}$ & PLS1, PLS2 & $\begin{array}{l}\text { Roegner et } \\
\text { al. 2007, } \\
2008\end{array}$ \\
\hline & & Unknown & MCR & & $>30$ & N/A & $\begin{array}{l}\text { Tidal } \\
\text { freshwater } \\
\text { swamp }\end{array}$ & $\mathrm{TN}$ & $\begin{array}{l}\text { Roegner et } \\
\text { al. } 2007\end{array}$ \\
\hline
\end{tabular}


Table 2.2. (contd)

\begin{tabular}{|c|c|c|c|c|c|c|c|c|c|}
\hline $\begin{array}{c}\text { Life } \\
\text { stage }\end{array}$ & Species & Run type & $\begin{array}{c}\text { River } \\
\text { section }\end{array}$ & RKM & $\begin{array}{l}\text { Length } \\
\text { (mm) }\end{array}$ & $\begin{array}{l}\text { Movement } \\
\text { rate } \\
(\mathrm{km} / \text { day })^{(\mathrm{a})}\end{array}$ & $\begin{array}{l}\text { Habitat } \\
\text { use }^{(\mathrm{b})}\end{array}$ & $\begin{array}{l}\text { Sampling } \\
\operatorname{method}(\mathrm{s})^{(\mathrm{c})}\end{array}$ & Citation \\
\hline \multirow{17}{*}{ 흥 } & \multirow{17}{*}{ 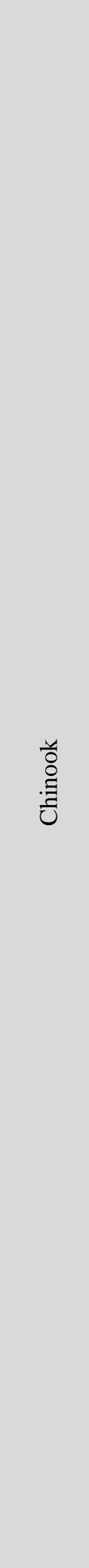 } & $\begin{array}{l}\text { Spring/ } \\
\text { Summer }\end{array}$ & $\begin{array}{c}\text { BON- } \\
\text { VAN \& } \\
\text { LCR }\end{array}$ & 219-89 & 139-163 & 81.6 & & RT & $\begin{array}{l}\text { Schreck et al. } \\
2005\end{array}$ \\
\hline & & $\begin{array}{l}\text { Spring/ } \\
\text { Summer }\end{array}$ & $\begin{array}{c}\text { BON- } \\
\text { VAN \& } \\
\text { LCR }\end{array}$ & 219-46 & 139-169 & $\begin{array}{c}67-79 \\
\text { (medians) }\end{array}$ & & RT, AT & $\begin{array}{l}\text { Schreck et al. } \\
2005\end{array}$ \\
\hline & & $\begin{array}{l}\text { Spring/ } \\
\text { Summer }\end{array}$ & $\begin{array}{c}\text { BON- } \\
\text { VAN \& } \\
\text { LCR }\end{array}$ & $235-8$ & $103-260$ & 19-179 & & JSATS & $\begin{array}{c}\text { PNNL } \\
\text { unpublished } \\
\text { data }\end{array}$ \\
\hline & & $\begin{array}{l}\text { Spring/ } \\
\text { Summer }\end{array}$ & $\begin{array}{c}\text { BON- } \\
\text { VAN \& } \\
\text { LCR }\end{array}$ & 233-113 & $103-260$ & 26-107 & $\begin{array}{l}96 \% \text { NAV; } \\
4 \% \text { side }\end{array}$ & JSATS & $\begin{array}{c}\text { PNNL } \\
\text { unpublished } \\
\text { data }\end{array}$ \\
\hline & & Spring & LCR & 83-61 & & 68-91 & $\begin{array}{l}\text { Mid- } \\
\text { channel }\end{array}$ & PIT & $\begin{array}{l}\text { Ledgerwood et } \\
\text { al. } 2004\end{array}$ \\
\hline & & Spring & LCR & $83-61$ & & $61-73$ & $\begin{array}{l}\text { Mid- } \\
\text { channel }\end{array}$ & PIT & $\begin{array}{l}\text { Ledgerwood et } \\
\text { al. } 2004\end{array}$ \\
\hline & & Spring & LCR & $75-16$ & 95-175 & $5-59$ & $\begin{array}{l}\text { Channel } \\
\text { margin }\end{array}$ & BS, PS & $\begin{array}{c}\text { Dawley et al. } \\
1986\end{array}$ \\
\hline & & Spring & LCR & 47 & & & $\begin{array}{l}99 \% \text { NAV; } \\
1 \% \text { other }\end{array}$ & RT, AT & $\begin{array}{c}\text { Schreck et al. } \\
2005\end{array}$ \\
\hline & & Spring & LCR & 75 & & & $\begin{array}{c}\text { Mid- } \\
\text { channel }\end{array}$ & BS, PS & $\begin{array}{l}\text { Ledgerwood et } \\
\text { al. } 1991\end{array}$ \\
\hline & & $\begin{array}{l}\text { Spring/ } \\
\text { Summer }\end{array}$ & LCR & $113-8$ & $103-260$ & 25-113 & $\begin{array}{l}\text { 73\% NAV; } \\
\text { 15\% side; } \\
18 \% \text { GB }\end{array}$ & JSATS & $\begin{array}{c}\text { PNNL } \\
\text { unpublished } \\
\text { data }\end{array}$ \\
\hline & & $\begin{array}{l}\text { Spring/ } \\
\text { Summer }\end{array}$ & $\begin{array}{c}\text { LCR \& } \\
\text { MCR }\end{array}$ & 47-0 & 144-179 & $\begin{array}{c}\text { 10-87 } \\
\text { (medians) }\end{array}$ & $\begin{array}{l}66 \% \text { NAV, } \\
34 \% \text { other }\end{array}$ & AT & $\begin{array}{l}\text { Schreck et al. } \\
2005\end{array}$ \\
\hline & & Spring & $\begin{array}{c}\text { LCR \& } \\
\text { MCR }\end{array}$ & $75-0$ & 95-175 & $1-68$ & $\begin{array}{l}\text { channel } \\
\text { margin }\end{array}$ & BS, PS & $\begin{array}{c}\text { Dawley et al. } \\
1986\end{array}$ \\
\hline & & $\begin{array}{l}\text { Spring/ } \\
\text { Summer }\end{array}$ & $\begin{array}{c}\text { LCR \& } \\
\text { MCR }\end{array}$ & $8-2$ & $103-260$ & 64-178 & & JSATS & $\begin{array}{c}\text { PNNL } \\
\text { unpublished } \\
\text { data }\end{array}$ \\
\hline & & Fall & $\begin{array}{c}\text { BON- } \\
\text { VAN \& } \\
\text { LCR }\end{array}$ & 233-75 & $56-77$ & $4.8-35.2$ & $\begin{array}{c}98 \% \\
\text { channel } \\
\text { margin; } 2 \% \\
\text { NAV }\end{array}$ & $\begin{array}{c}\mathrm{BS}, \mathrm{PS}, \\
\mathrm{T}\end{array}$ & $\begin{array}{c}\text { Dawley et al. } \\
1986\end{array}$ \\
\hline & & Fall & $\begin{array}{c}\text { BON- } \\
\text { VAN \& } \\
\text { LCR }\end{array}$ & 219-89 & & $36-79$ & & $\mathrm{RT}$ & $\begin{array}{l}\text { Schreck et al. } \\
2005\end{array}$ \\
\hline & & Fall & $\begin{array}{c}\text { BON- } \\
\text { VAN \& } \\
\text { LCR }\end{array}$ & 219-89 & & $43-82$ & & $\mathrm{RT}$ & $\begin{array}{l}\text { Schreck et al. } \\
2005\end{array}$ \\
\hline & & Fall & $\begin{array}{c}\text { BON- } \\
\text { VAN \& } \\
\text { LCR }\end{array}$ & $235-8$ & $94-230$ & $41-72$ & & JSATS & $\begin{array}{c}\text { PNNL } \\
\text { unpublished } \\
\text { data }\end{array}$ \\
\hline
\end{tabular}


Table 2.2. (contd)

\begin{tabular}{|c|c|c|c|c|c|c|c|c|c|}
\hline $\begin{array}{c}\text { Life } \\
\text { stage }\end{array}$ & Species & Run type & $\begin{array}{c}\text { River } \\
\text { section }\end{array}$ & RKM & $\begin{array}{c}\begin{array}{c}\text { Length } \\
(\mathrm{mm})\end{array} \\
\end{array}$ & $\begin{array}{c}\text { Movement } \\
\text { rate } \\
(\mathrm{km} / \text { day })^{(\mathrm{a})}\end{array}$ & $\begin{array}{c}\text { Habitat } \\
\text { use }^{(\mathrm{b})}\end{array}$ & $\begin{array}{l}\text { Sampling } \\
\operatorname{method}(\mathrm{s})^{(\mathrm{c})}\end{array}$ & Citation \\
\hline \multirow{18}{*}{ 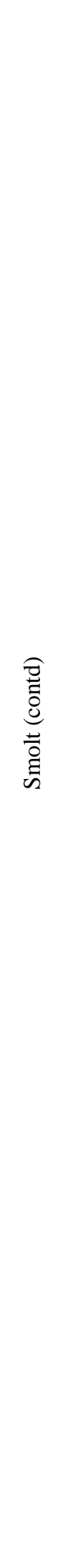 } & \multirow{11}{*}{ 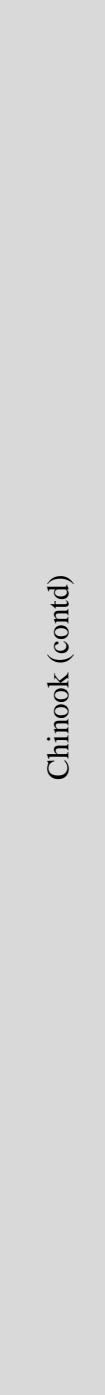 } & Fall & $\begin{array}{c}\text { BON-VAN } \\
\& \text { LCR }\end{array}$ & 233-113 & $94-230$ & 55-83 & $\begin{array}{l}98 \% \\
\text { NAV; } 2 \% \\
\text { side }\end{array}$ & JSATS & $\begin{array}{c}\text { PNNL } \\
\text { unpublished } \\
\text { data }\end{array}$ \\
\hline & & Fall & LCR & $75-16$ & 130-157 & $2-59$ & $\begin{array}{c}98 \% \\
\text { channel } \\
\text { margin; } \\
2 \% \text { NAV }\end{array}$ & BS, PS & $\begin{array}{c}\text { Dawley et al. } \\
1986\end{array}$ \\
\hline & & Fall & LCR & 47 & & & $\begin{array}{c}99 \% \\
\text { NAV; } 1 \% \\
\text { other }\end{array}$ & & $\begin{array}{l}\text { Schreck et } \\
\text { al. } 2005\end{array}$ \\
\hline & & Fall & LCR & 75 & & & $\begin{array}{l}\text { channel } \\
\text { margin }\end{array}$ & BS, PS & $\begin{array}{c}\text { Ledgerwood } \\
\text { et al. } 1991\end{array}$ \\
\hline & & Fall & LCR & 40 & 50-90 & & $\begin{array}{c}\text { Side } \\
\text { channels }\end{array}$ & $\mathrm{TN}$ & $\begin{array}{l}\text { Roegner et } \\
\text { al. } 2004\end{array}$ \\
\hline & & Fall & LCR & $113-8$ & $94-230$ & $27-83$ & $\begin{array}{c}67 \% \\
\text { NAV; } \\
\text { 10\% side; } \\
23 \% \text { GB }\end{array}$ & JSATS & $\begin{array}{c}\text { PNNL } \\
\text { unpublished } \\
\text { data }\end{array}$ \\
\hline & & Fall & $\begin{array}{c}\text { LCR \& } \\
\text { MCR }\end{array}$ & 75-1 & $56-77$ & $12.3-74.0$ & $\begin{array}{c}98 \% \\
\text { channel } \\
\text { margin; } \\
2 \% \text { NAV }\end{array}$ & BS, PS, T & $\begin{array}{c}\text { Dawley et al. } \\
1986\end{array}$ \\
\hline & & Fall & $\begin{array}{c}\text { LCR \& } \\
\text { MCR }\end{array}$ & $75-0$ & 130-157 & 1-99 & $\begin{array}{c}98 \% \\
\text { channel } \\
\text { margin; } \\
\text { 2\% NAV }\end{array}$ & BS, PS, T & $\begin{array}{c}\text { Dawley et al. } \\
1986\end{array}$ \\
\hline & & Fall & $\begin{array}{c}\text { LCR \& } \\
\text { MCR }\end{array}$ & $47-0$ & & & $\begin{array}{c}66 \% \\
\text { NAV; } \\
34 \% \text { other }\end{array}$ & & $\begin{array}{l}\text { Schreck et } \\
\text { al. } 2005\end{array}$ \\
\hline & & Fall & $\begin{array}{c}\text { LCR \& } \\
\text { MCR }\end{array}$ & $47-0$ & 37-185 & & $\begin{array}{l}95 \% \text { IP; } \\
5 \% \text { other }\end{array}$ & BS, PS & $\begin{array}{l}\text { McCabe et } \\
\text { al. } 1986\end{array}$ \\
\hline & & Fall & $\begin{array}{l}\text { LCR \& } \\
\text { MCR }\end{array}$ & $8-2$ & $94-230$ & 16-136 & & JSATS & $\begin{array}{c}\text { PNNL } \\
\text { unpublished } \\
\text { data }\end{array}$ \\
\hline & \multirow{7}{*}{ 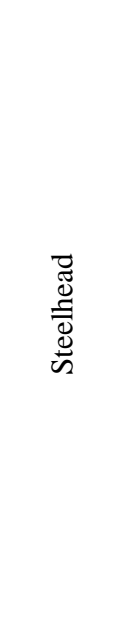 } & & $\begin{array}{c}\text { BON-VAN } \\
\text { \& LCR }\end{array}$ & 233-75 & & $\begin{array}{c}61-83 \\
\text { (medians) }\end{array}$ & & $\mathrm{RT}$ & $\begin{array}{c}\text { Ledgerwood } \\
\text { et al. } 2004\end{array}$ \\
\hline & & & $\begin{array}{c}\text { BON-VAN } \\
\& \text { LCR }\end{array}$ & 233-75 & & $\begin{array}{c}57-78 \\
\text { (medians) }\end{array}$ & & RT & $\begin{array}{c}\text { Ledgerwood } \\
\text { et al. } 2004\end{array}$ \\
\hline & & & $\begin{array}{c}\text { BON-VAN } \\
\& \text { LCR }\end{array}$ & 219-89 & & 50-101 & & $\mathrm{RT}$ & $\begin{array}{l}\text { Schreck et } \\
\text { al. } 2005\end{array}$ \\
\hline & & & $\begin{array}{c}\text { BON-VAN } \\
\& \text { LCR }\end{array}$ & 219-89 & & 55-108 & & RT & $\begin{array}{l}\text { Schreck et } \\
\text { al. } 2005\end{array}$ \\
\hline & & & LCR & 83-61 & & 66-93 & $\begin{array}{c}\text { Mid- } \\
\text { channel }\end{array}$ & PIT & $\begin{array}{c}\text { Ledgerwood } \\
\text { et al. } 2004\end{array}$ \\
\hline & & & LCR & 83-61 & & $67-88$ & $\begin{array}{l}\text { Mid- } \\
\text { channel }\end{array}$ & PIT & $\begin{array}{l}\text { Ledgerwood } \\
\text { et al. } 2004\end{array}$ \\
\hline & & & LCR & 75-16 & 155-230 & $20-59$ & $\begin{array}{l}\text { Channel } \\
\text { margin }\end{array}$ & BS, PS & $\begin{array}{c}\text { Dawley et al. } \\
1986\end{array}$ \\
\hline
\end{tabular}


Table 2.2. (contd)

\begin{tabular}{|c|c|c|c|c|c|c|c|c|c|}
\hline $\begin{array}{l}\text { Life } \\
\text { stage }\end{array}$ & Species & $\begin{array}{l}\text { Run } \\
\text { type }\end{array}$ & $\begin{array}{l}\text { River } \\
\text { section }\end{array}$ & RKM & $\begin{array}{l}\text { Length } \\
(\mathrm{mm})\end{array}$ & $\begin{array}{l}\text { Movement } \\
\text { rate } \\
(\mathrm{km} / \text { day })^{(a)}\end{array}$ & $\begin{array}{c}\text { Habitat } \\
\text { use }^{(b)}\end{array}$ & $\begin{array}{l}\text { Sampling } \\
\operatorname{method}(\mathrm{s})^{(\mathrm{c})}\end{array}$ & Citation \\
\hline \multirow{5}{*}{ 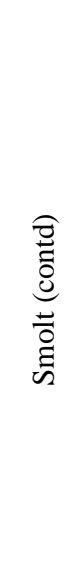 } & \multirow{4}{*}{ 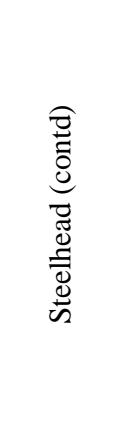 } & & LCR & 46 & & & $\begin{array}{c}95 \% \\
\text { NAV; } \\
5 \% \text { side }\end{array}$ & RT, AT & $\begin{array}{c}\text { Schreck et al. } \\
2005\end{array}$ \\
\hline & & & LCR & 75 & & & $\begin{array}{c}\text { Mid- } \\
\text { channel }\end{array}$ & BS, PS & $\begin{array}{c}\text { Ledgerwood } \\
\text { et al. } 1991\end{array}$ \\
\hline & & & $\begin{array}{l}\text { LCR \& } \\
\text { MCR }\end{array}$ & $75-0$ & $\begin{array}{c}155- \\
230\end{array}$ & $1-62$ & $\begin{array}{l}\text { Channel } \\
\text { margin }\end{array}$ & BS, PS & $\begin{array}{c}\text { Dawley et al. } \\
1986\end{array}$ \\
\hline & & & $\begin{array}{c}\text { LCR \& } \\
\text { MCR }\end{array}$ & $46-0$ & & & $\begin{array}{c}70 \% \\
\text { NAV; } \\
30 \%\end{array}$ & RT, AT & $\begin{array}{c}\text { Schreck et al. } \\
2005\end{array}$ \\
\hline & 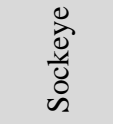 & & LCR & $>46$ & & & $\begin{array}{c}\text { Mid- } \\
\text { channel }\end{array}$ & PS & $\begin{array}{c}\text { Johnsen and } \\
\text { Sims } 1973\end{array}$ \\
\hline
\end{tabular}

(a) Movement rates are expressed as mean kilometers per day unless otherwise noted.

(b) Habitat use was classified as the location of sampling or the route of travel determined by the sampling method. Habitats are navigation channel (NAV), side channel (side), Grays Bay (GB), and intertidal/pelagic zone (IP).

(c) Sampling methods are beach seine (BS), purse seine (PS), trap net (TN), trawl (T), pole seine (PLS1), pull seine (PLS2), fyke net (FN), Juvenile Salmon Acoustic Telemetry System (JSATS), radio telemetry (RT), acoustic telemetry (AT), trap net (TN), and passive integrated transponder (PIT) trawl.

Proximity to the estuary at the start of migration also seems to affect the migration rate through the Columbia River estuary. Dawley et al. (1986) reported that hatchery fish released near the estuary generally moved downstream at a slower rate than their counterparts from hatcheries farther upstream. The same trend was observed for hatchery-reared juvenile coho salmon.

Larger fish are less likely to rear in the estuary for additional periods of growth before entering the ocean, and thus tend to travel through the estuary at a faster rate than smaller fish. Therefore, studies that typically use the larger hatchery-reared fish may underestimate estuary residence (Bottom et al. 2008). River discharge can also affect juvenile salmon migration rates, with faster migration rates occurring during high discharge periods (Dawley et al. 1986). Juvenile salmon also tend to migrate more rapidly later in their migration season (Ledgerwood et al. 2004; McMichael et al. 2006b; McComas et al. 2008).

Schreck and Stahl (1998) reported that movement in the lower estuary was influenced by tidal cycles, with fish moving downstream on the ebb tide and holding or moving upstream during the flood tide. Radio-tagged coho salmon in the Grays Harbor estuary were also influenced by flow, with periods of passive downstream movement in strong currents and periods of holding in low-velocity habitats (Bottom et al. 2005). Steelhead, on the other hand, were less influenced by tidal flows and generally tended to achieve a net downstream movement, regardless of the tidal cycle (Schreck et al. 2005).

Movement of juvenile salmonids through the estuary occurs throughout the day, with more movement during daylight hours (Dawley et al. 1986; Ledgerwood et al. 1991; Carlson et al. 2001). The decrease in movement at night was consistent between sample sites at Jones Beach and Puget Island (Dawley et al. 1986). Diel movement patterns did not appear to be influenced by tidal conditions and were consistent 
between years (Dawley et al. 1986, Ledgerwood et al. 1991). Studies using beach and purse seines found yearling and subyearling Chinook salmon were most likely to be present between sunrise and early afternoon (Ledgerwood et al. 1991). Coho were present throughout the period of daylight (Dawley et al. 1986; Ledgerwood et al. 1991; Pearson et al. 2005), and steelhead were caught mainly between noon and early evening (Ledgerwood et al. 1991). A study using PIT-tag detections in a surface pair-trawl detected more yearling Chinook salmon during dark than during daylight (19.1 vs. 8.4 fish/h), but there was no significant difference in detection rates of steelhead between darkness and daylight (Ledgerwood et al. 2004). It is unclear whether these capture data truly reflect fish abundance. It is possible that fish susceptibility to capture in these gear types may be influenced by light levels. For example, it is possible that fish are more likely to avoid being captured in a net or entrained in a trawl during daylight than during night.

\subsection{Use of the Columbia River Plume by Juvenile Anadromous Salmonids}

The Columbia River plume can be defined as the layer of Columbia River water in the nearshore Pacific Ocean. The plume can be identified by a reduced salinity contour near the ocean surface of 31 parts per thousand (Fresh et al. 2005). The location and extent of the Columbia River plume varies seasonally with discharge, winds, and ocean currents, but it is typically located on the continental shelf off the Washington coast during fall and winter and beyond the shelf off the Oregon coast during spring and summer (Hickey and Banas 2003; NMFS 2006). Evidence suggests that the plume is a food-rich habitat where juvenile salmonids have the opportunity for significant growth as they adjust their physiology to the more saline ocean environment (NMFS 2006). Sediment and nutrients transported in the plume benefit juvenile salmonids by providing refuge from predators and by fueling primary productivity. The plume may also benefit juvenile salmonids by distributing them away from predation pressure that occurs closer to shore and by concentrating food sources such as zooplankton (Fresh et al. 2005).

Many Columbia River salmonids, such as yearling coho salmon, yearling Chinook salmon, chum salmon, and steelhead, enter the ocean during late spring and early summer when river flows are high and the low-salinity plume is well developed (De Robertis et al. 2005). During 12 days of surface trawling in May of 2001 and 2002, densities of juvenile yearling coho salmon, yearling Chinook salmon, and steelhead were generally higher in the plume compared to more marine waters, reflecting the outmigration of large numbers of juvenile salmon from the Columbia River estuary into coastal waters during this time (De Robertis et al. 2005). Chum salmon were rare in the plume, possibly because Columbia River chum salmon populations were at low levels during the time of this study (De Robertis et al. 2005). However, juvenile chum salmon have been found to use riverine plume habitats as nursery areas in other regions (Fukuwaka and Suzuki 1998).

While in the plume and adjacent waters, yearling coho and yearling Chinook salmon feed on a variety of forage fish, crab megalopae, adult euphausiids, pteropods, and hyperiid amphipods, whereas juvenile chum salmon seem to feed exclusively on planktonic prey (De Robertis et al. 2005). Juvenile salmonids captured outside the plume are often larger in size and have fuller stomachs than those captured in the plume (Fisher and Pearcy 1995; De Robertis et al. 2005). These results suggest that once fish made the 
physiological transition to a marine habitat and reached a size at which they were less vulnerable to predation, they moved away from the plume to more marine waters where feeding opportunities were better (De Robertis et al. 2005).

Samples from trawls, seines, and net tows have found that most Columbia River yearling Chinook salmon migrate north, out of the plume area, by June (Fisher and Pearcy 1995; Van Doornik et al. 2007; Casillas et al. 2008). Although most yearling coho salmon migrate out of the plume area by late summer, they are more abundant than yearling Chinook salmon in the plume and off the coast of Washington during this time (Pearcy and Fisher 1988; Van Doornik et al. 2007; Casillas et al. 2008), suggesting that they are less migratory than yearling Columbia River Chinook salmon during their first summer in the ocean (Fisher and Pearcy 1995).

Subyearling Chinook salmon typically enter the ocean during mid to late summer (Emmet et al. 2006; Casillas et al. 2008) and may overwinter in the waters near or adjacent to the mouth of the Columbia River (Fisher and Pearcy 1995; Casillas et al. 2008). Subyearlings appear to be more strongly associated with shallow, nearshore areas of the Columbia River plume compared to yearling Chinook salmon (Fisher and Pearcy 1995). This behavior makes subyearling Chinook salmon more susceptible to processes affecting the nearshore environment, such as storms that cause heavy surf conditions, concentrations of nearshore predators, and nearshore dredging and other habitat modifications (Fisher and Pearcy 1995). However, by staying near shore, where southward currents are not as strong during summer compared to 15-20 km farther offshore (Kundu and Allen 1976; Huyer 1983), northward movements of the small subyearling fish may be facilitated (Fisher and Pearcy 1995).

The use of the Columbia River plume by pink salmon, which migrate to the ocean as fry, is unknown. However, fry and small fingerlings ( $<80 \mathrm{~mm}$ ) have not been captured in the plume (Fresh et al. 2003). This may be because small fish do not use the plume or that the sampling methods or the timing of sampling missed these small fish. Because pink salmon are relatively rare in the Columbia River (Hard et al. 1996), it is likely that their absence from trawl catches indicates that they are not present in the plume in large numbers.

Columbia River anadromous cutthroat trout migrate to saltwater at age 2 to 7 in April and early May (Dawley et al. 1978, 1979, 1980; Loch and Miller 1988). Coastal cutthroat trout remain relatively close to shore while at sea compared to other anadromous salmonids; they do not cross bodies of deep open water (Trotter 1989) but may migrate considerable distances within the plume. Coastal cutthroat trout have been captured within the Columbia River plume as far as 31.5 km offshore (Loch and Miller 1988). Cutthroat trout are mainly piscivorous while in or adjacent to the plume, feeding on juvenile cabezon Scorpaenichthys marmoratus, Pacific sand lance Ammodytes hexapterus, northern anchovies Engravalis mordax, juvenile kelp greenling Hexagrammus decagrammus, and rockfishes Sebastes spp (Brodeur et al. 1987; Loch and Miller 1988). Principal prey items also include mysids, brachyuran crab megalops, and euphausiids (Loch and Miller 1988). Cutthroat trout have been reported to leave the plume, re-entering the Columbia River estuary in early June (Loch 1982; Loch and Miller 1988).

Estimates of Columbia River juvenile salmon density obtained during the summer/fall from nearshore ocean environments have been highly correlated with the number of adults returning to Bonneville Dam (Van Doornik et al. 2007; Casillas et al. 2008). These correlations indicate that ocean survival is set relatively early in the juvenile salmon's ocean residence (Casillas et al. 2008) and emphasize the importance of the Columbia River plume and nearshore environments to the early marine phase of the 
juvenile migration. Because the plume is the first area encountered by juvenile salmonids upon ocean entry, changes in the structure of the plume may significantly influence the distribution, growth, and survival of Columbia River salmonids (De Robertis et al. 2005).

The Columbia River plume has changed considerably in the past 200 years (NMFS 2006). Changes to the hydrograph, which are attributed to flow regulation by the hydroelectric system, water withdrawal for irrigation and water supplies, and climate fluctuations, have altered the timing, magnitude, and duration of river flows. These changes have affected erosion and accretion processes in the river, estuary, plume, and nearshore ocean environments (NMFS 2006). Since the construction of dams, the amount of sand and gravel entering the estuary and plume has been severely reduced, while dredging activities have exported sand and gravel out of the estuary at a rate three times higher than it enters (Lower Columbia Fish Recovery Board 2004). Additionally, dredging and the construction of jetties have limited wave action and the supply of marine sediment to the plume area (NMFS 2006). The reduced transport of sediment to the plume likely influences habitat-forming processes, nutrient levels, and food sources, and may increase predation pressure on juvenile salmonids because of increased visibility (Bottom et al. 2005; Fresh et al. 2005; NMFS 2006). Although the natural transport of sediment to the Columbia River plume has been reduced, dredge material has been disposed of in the area of the plume (NMFS 2006), which has altered the habitat available to juvenile salmonids and may attract colonies of piscovorous birds, as is common in the Columbia River estuary (Collis et al. 2002; Antolos et al. 2005; Roby et al. 2005). 


\subsection{Juvenile Salmon Acoustic Telemetry System Data Synthesis}

The Juvenile Salmonid Acoustic Telemetry System (JSATS) tools were developed in response to a lack of information on survival and behavior of juvenile anadromous salmonids specific to the lower Columbia River and its estuary. In 2001, the USACE, NOAA Fisheries, and PNNL initiated a project to develop tools to provide rigorous survival estimation for juvenile salmonids. Acoustic telemetry was chosen as the only viable option for an existing technology that would allow for tagging individual fish of small size and being able to remotely detect them in both fresh and saltwater. Subyearling Chinook salmon were of particular interest, and to effectively tag these fish, of which only about $85 \%$ of the population is $\geq 92 \mathrm{~mm}$ ( $3.5 \mathrm{in}$ ) fork length at the time they reach Bonneville Dam, a small, ergonomic transmitter was developed (McComas et al. 2005; McMichael et al. in review). Receiving equipment was developed to detect these tags; a pilot-scale effort in 2004 used live fish tagged and released at Bonneville Dam and a few receivers deployed in the Columbia River estuary.

\subsection{Migratory Behavior Characterization Methodology}

Since 2004, nearly 65,000 juvenile steelhead and Chinook salmon tagged with JSATS acoustic transmitters have been released from the Clearwater River down through the Snake and Columbia rivers (Table 3.1). The data summarized in this report make use of detections of these fishes on acoustic receivers deployed in the Columbia River from Bonneville Dam to the Pacific Ocean. Table 3.2 describes where the acoustic receivers were deployed each year. Figure 3.1 through 3.5 show the placement of JSATS receivers between Bonneville Dam and the mouth of the Columbia River (MCR) for 2004 through 2008. Thorough descriptions of fish collection, tagging, and handling, as well as receiver equipment protocols and specifications, can be found in McMichael et al. (2006a, 2008), Cook et al. (2007), McComas et al. (2007, 2008), and Ploskey et al. (2007).

Table 3.1. Numbers, date, and size range of releases of acoustic tagged fish, 2004 through 2008. Release location abbreviations are as follows: Bonneville Dam (BON), John Day Dam (JDA), Little Goose Dam (LGS), Lower Granite Dam (LGR), Skamania Landing (SKA), The Dalles Dam (TDA), corner collector (CC), tailrace (TR). The release river kilometer (RKM) value is the combined distance from the mouth of the Columbia River.

\begin{tabular}{ccccccccc}
\hline & & & Release & & & \multicolumn{3}{c}{ Fork length } \\
\cline { 7 - 9 } Year & Species/Run & Release location & RKM & Release dates & N & Min & Max & Median \\
\hline 2004 & CH1 & BON TR & 233 & 16 May-29 May & 963 & 123 & 215 & 150 \\
2005 & CH1 & BON TR & 233 & 4 May-1 June & 896 & 116 & 226 & 151 \\
2005 & CH0 & BON TR & 233 & 18 June-16 July & 1220 & 96 & 147 & 108 \\
2005 & STL & SKA & 227 & 7 May-23 May & 640 & 177 & 304 & 241 \\
2005 & CH1 & $\begin{array}{c}\text { S. Fork Klaskanine } \\
\text { Hatchery }\end{array}$ & 80 & 5 April & 75 & 105 & 191 & 157 \\
2005 & CH1 & Young's Bay YC & 23 & 6 April & 31 & 109 & 174 & 144 \\
\hline
\end{tabular}


Table 3.1. (contd)

\begin{tabular}{|c|c|c|c|c|c|c|c|c|}
\hline \multirow[b]{2}{*}{ Year } & \multirow[b]{2}{*}{ Species/Run } & \multirow[b]{2}{*}{ Release location } & \multirow{2}{*}{$\begin{array}{c}\text { Release } \\
\text { RKM }\end{array}$} & \multirow[b]{2}{*}{ Release dates } & \multirow[b]{2}{*}{$\mathrm{N}$} & \multicolumn{3}{|c|}{ Fork length } \\
\hline & & & & & & Min & $\operatorname{Max}$ & Median \\
\hline 2005 & STL & Astoria Bridge & 22 & 7 Маy-23 Мay & 396 & 182 & 290 & 242 \\
\hline 2005 & CH1 & $\begin{array}{c}\text { Hammond } \\
\text { Channel }\end{array}$ & 19 & 6 April & 35 & 116 & 188 & 144 \\
\hline 2006 & $\mathrm{CH} 1$ & LGR TR & 695 & 6 May-13 May & 996 & 105 & 160 & 137 \\
\hline 2006 & CHO & LGS TR & 629 & 16 June-18 July & 1949 & 94 & 136 & 111 \\
\hline 2006 & CH1 & JDA TR & 349 & 16 May-3 June & 1500 & 108 & 222 & 142 \\
\hline 2006 & СHO & JDA TR & 349 & 13 June-27 June & 300 & 95 & 140 & 109 \\
\hline 2006 & $\mathrm{CH} 1$ & TDA TR & 306 & 16 May-5 June & 1000 & 116 & 214 & 143 \\
\hline 2006 & CHO & TDA TR & 306 & 13 June-13 July & 2202 & 95 & 209 & 110 \\
\hline 2006 & $\mathrm{CH} 1$ & BON TR & 234 & 2 Мay-27 May & 974 & 116 & 218 & 148 \\
\hline 2006 & CHO & BON TR & 234 & 16 June-22 July & 1955 & 94 & 155 & 109 \\
\hline 2007 & $\mathrm{CHO}$ & Clearwater & 803 & 18 Aug-17 Oct & 410 & 96 & 170 & 138 \\
\hline 2007 & CH1 & LGR TR & 695 & 25 April-15 May & 3817 & 95 & 168 & 133 \\
\hline 2007 & $\mathrm{CHO}$ & LGR TR & 695 & 5 June-14 July & 9836 & 83 & 146 & 103 \\
\hline 2007 & $\mathrm{CHO}$ & LGS TR & 631 & 31 July-13 Oct & 1771 & 109 & 230 & 152 \\
\hline 2007 & CH1 & BON spillway & 235 & 1 May-25 May & 2990 & 116 & 228 & 142 \\
\hline 2007 & $\mathrm{CHO}$ & BON spillway & 235 & 21 June-13 July & 3189 & 93 & 158 & 105 \\
\hline 2007 & CH1 & BON TR & 234 & 1 May-2 June & 1787 & 116 & 228 & 143 \\
\hline 2007 & $\mathrm{CHO}$ & BON TR & 234 & 16 June-21 July & 2790 & 92 & 154 & 104 \\
\hline 2008 & CH1 & LGR TR & 695 & 24 April-21 May & 5442 & 74 & 202 & 137 \\
\hline 2008 & STL & Arlington & 390 & 1 Мау-28 Мау & 2453 & 143 & 271 & 217 \\
\hline 2008 & CH1 & Arlington & 390 & 1 May-28 May & 2451 & 110 & 232 & 157 \\
\hline 2008 & $\mathrm{CHO}$ & Arlington & 390 & 15 June-12 July & 2489 & 95 & 148 & 116 \\
\hline 2008 & STL & JDA TR & 344 & 2 Мay-29 May & 993 & 144 & 273 & 216 \\
\hline 2008 & CH1 & JDA TR & 344 & 2 Мау-29 Мау & 994 & 111 & 229 & 154 \\
\hline 2008 & CHO & JDA TR & 344 & 16 June-13 July & 996 & 97 & 147 & 115 \\
\hline 2008 & CHO & TDA TR & 306 & 16 June-13 July & 2446 & 95 & 148 & 115 \\
\hline 2008 & CH1 & BON CC & 235 & 30 April-2 June & 826 & 113 & 232 & 130 \\
\hline 2008 & CHO & BON CC & 235 & 15 June-19 July & 1020 & 95 & 151 & 112 \\
\hline 2008 & $\mathrm{CH} 1$ & BON TR & 231 & 30 April-2 June & 826 & 114 & 229 & 145 \\
\hline 2008 & CHO & BON TR & 231 & 15 June-19 July & 1020 & 81 & 159 & 112 \\
\hline 2008 & CH1 & SKA & 227 & 25 April-22 May & 1282 & 82 & 260 & 140 \\
\hline
\end{tabular}


Table 3.2. Acoustic receiver arrays, by river section, 2004 through 2008. Numbers of receivers are indicated for each array each year. The array code contains the river kilometer at which the array was located.

\begin{tabular}{|c|c|c|c|c|c|c|c|c|}
\hline River section & Array code & $\begin{array}{l}\text { River } \\
\text { mile }\end{array}$ & Location description & 2004 & 2005 & 2006 & 2007 & 2008 \\
\hline MCR & CR002.8 & 1.7 & $\begin{array}{l}\text { Columbia River entrance, } \\
\text { North Jetty to South Jetty }\end{array}$ & 6 & 33 & 25 & 31 & 31 \\
\hline \multirow{9}{*}{$\begin{array}{l}\text { Lower } \\
\text { Columbia River }\end{array}$} & CR008.3 & 5.2 & $\begin{array}{l}\text { Estuary, East Sand Island to } \\
\text { Clatsop Spit }\end{array}$ & 4 & 22 & 22 & 22 & 22 \\
\hline & CR035.6 & 22.1 & Main channel, Rice Island & & & & & 4 \\
\hline & CR049.6 & 30.8 & $\begin{array}{l}\text { Main channel, Three-Tree } \\
\text { Point }\end{array}$ & & & & & 3 \\
\hline & $\begin{array}{l}\text { CR029- } \\
\text { CR053 }\end{array}$ & $\begin{array}{l}18.2- \\
32.9\end{array}$ & $\begin{array}{l}\text { Grays Bay and estuary } \\
\text { islands }\end{array}$ & & & & 6 & 12 \\
\hline & CR058.0 & 36.3 & $\begin{array}{l}\text { Main channel, Tenasillahe } \\
\text { Island }\end{array}$ & & & & 7 & \\
\hline & CR084.0 & 52.2 & $\begin{array}{l}\text { Estuary islands, } \\
\text { downstream of Oak Point }\end{array}$ & & & & 4 & \\
\hline & CR086.2 & 53.6 & Estuary islands, Oak Point & & & & 5 & 4 \\
\hline & $\begin{array}{l}\text { CR095- } \\
\text { CR097 }\end{array}$ & $\begin{array}{l}59.0- \\
70.2\end{array}$ & Fisher/Hump Island Slough & & & & & 2 \\
\hline & CR113.0 & 70.2 & $\begin{array}{l}\text { Main channel, Cottonwood } \\
\text { Island }\end{array}$ & & & & 5 & 6 \\
\hline \multirow{4}{*}{$\begin{array}{l}\text { Vancouver to } \\
\text { Bonneville }\end{array}$} & CR193.0 & 119.9 & Main channel, Lady Island & & & 4 & 5 & 6 \\
\hline & CR204.0 & 125.5 & Main channel, Reed Island & & & 4 & 5 & 9 \\
\hline & CR210.0 & 129.7 & $\begin{array}{l}\text { Main channel, between } \\
\text { Rooster Rock and Cape } \\
\text { Horn }\end{array}$ & & & 4 & 6 & \\
\hline & CR224.0 & 139.2 & $\begin{array}{l}\text { Main channel, near the town } \\
\text { of Skamania }\end{array}$ & & & & 4 & \\
\hline
\end{tabular}




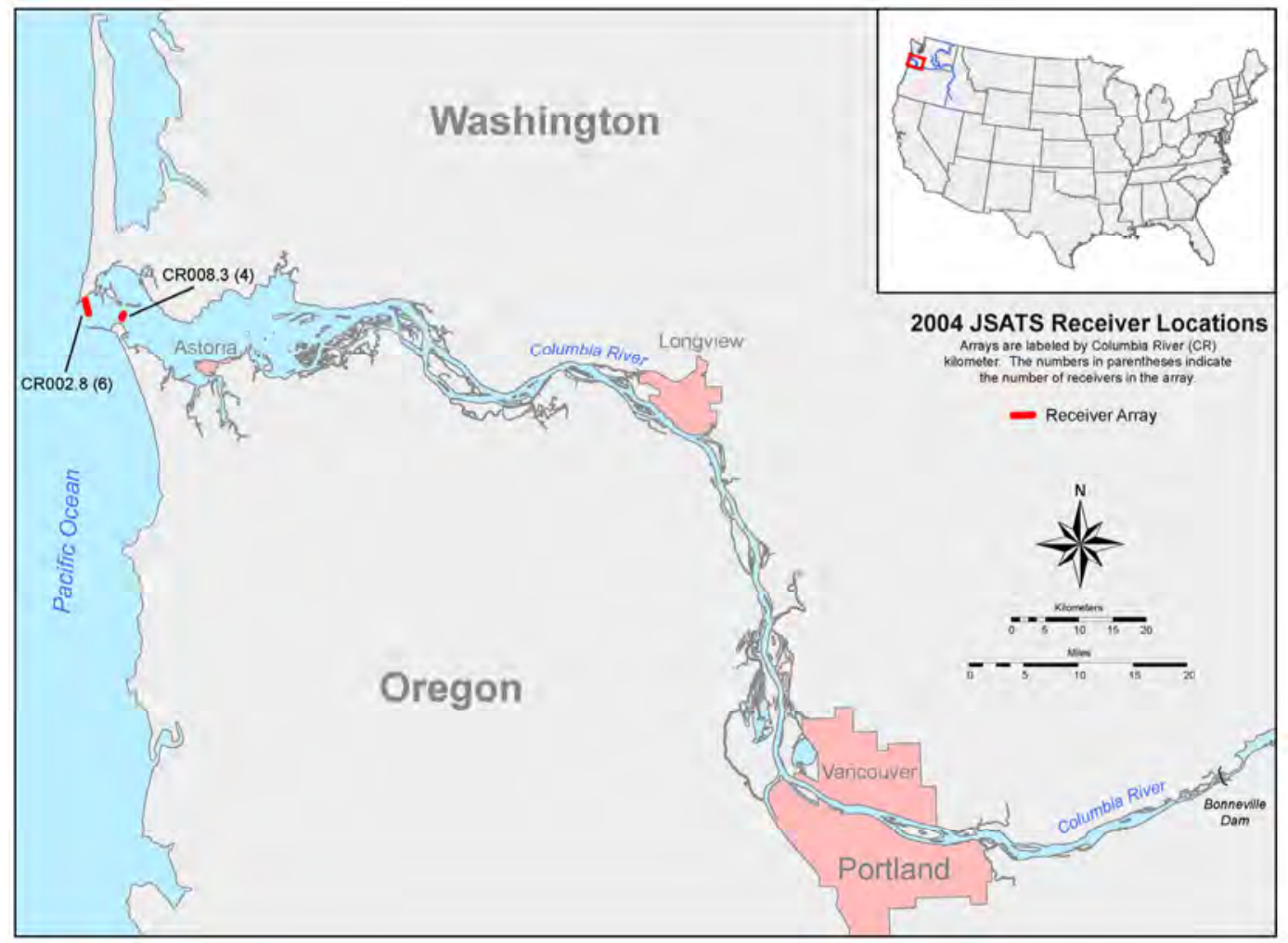

Figure 3.1. JSATS acoustic telemetry receivers in the lower Columbia River in 2004.

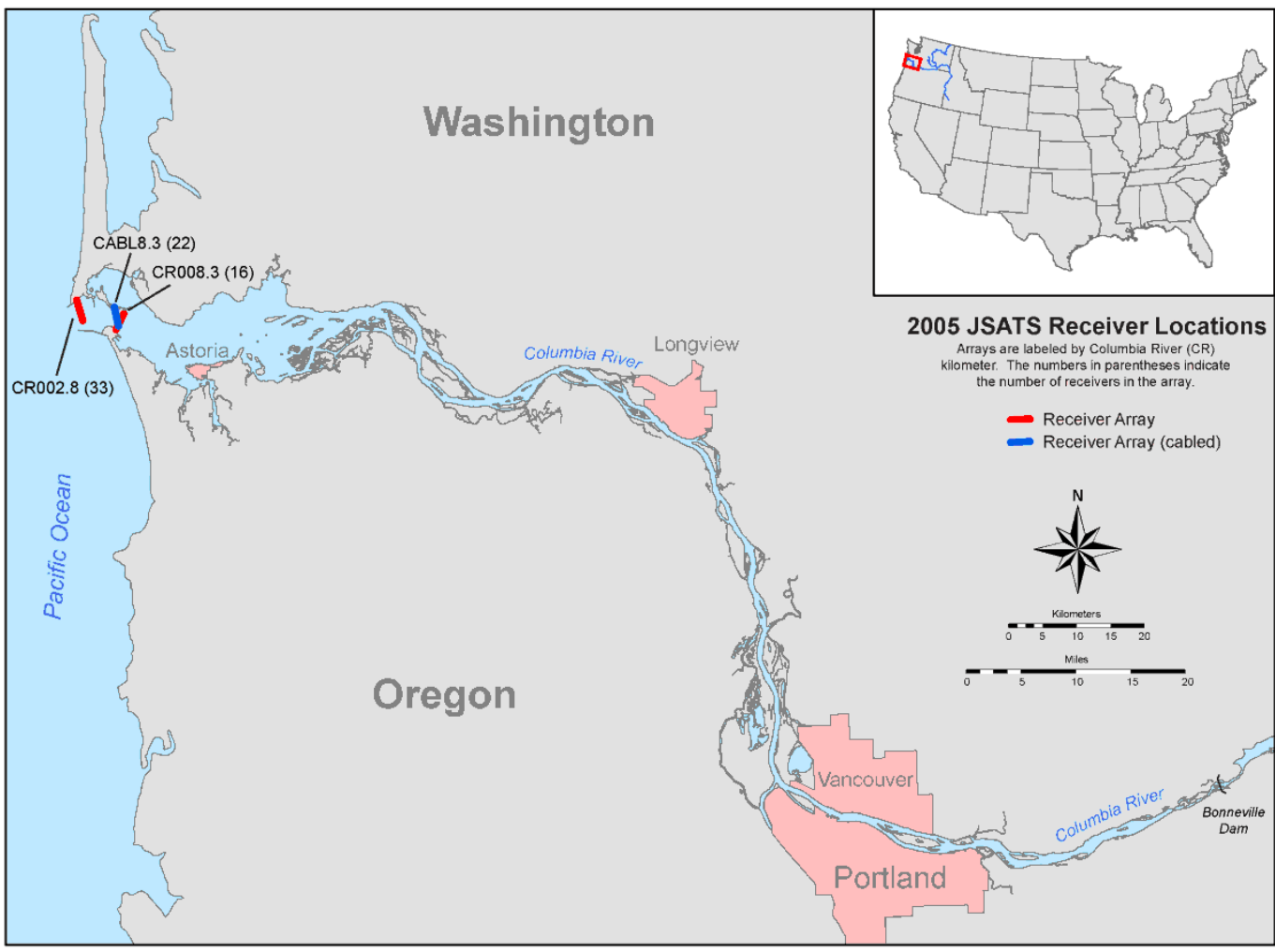

Figure 3.2. JSATS acoustic telemetry receivers in the lower Columbia River in 2005. 


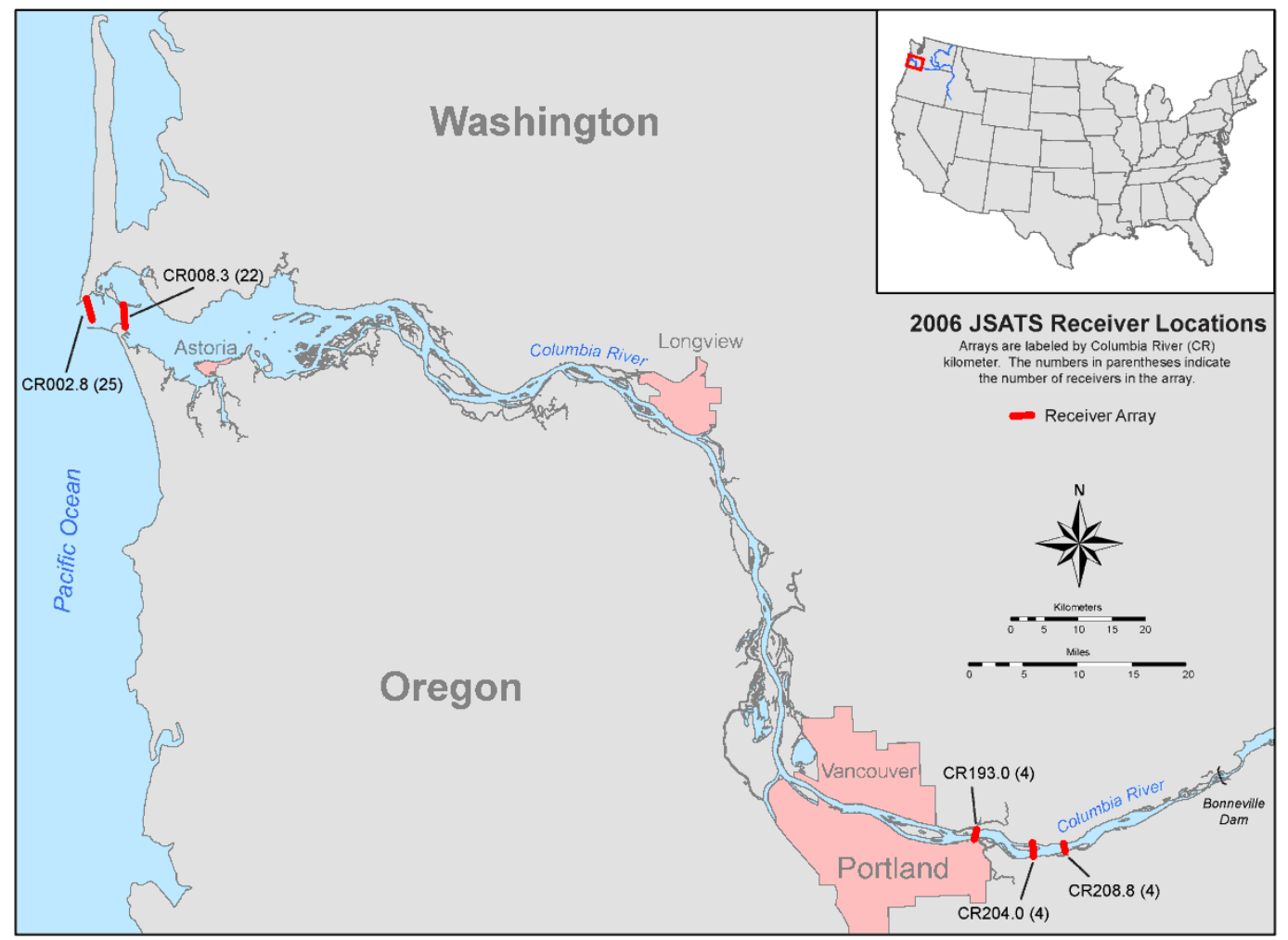

Figure 3.3. JSATS acoustic telemetry receivers in the lower Columbia River in 2006.

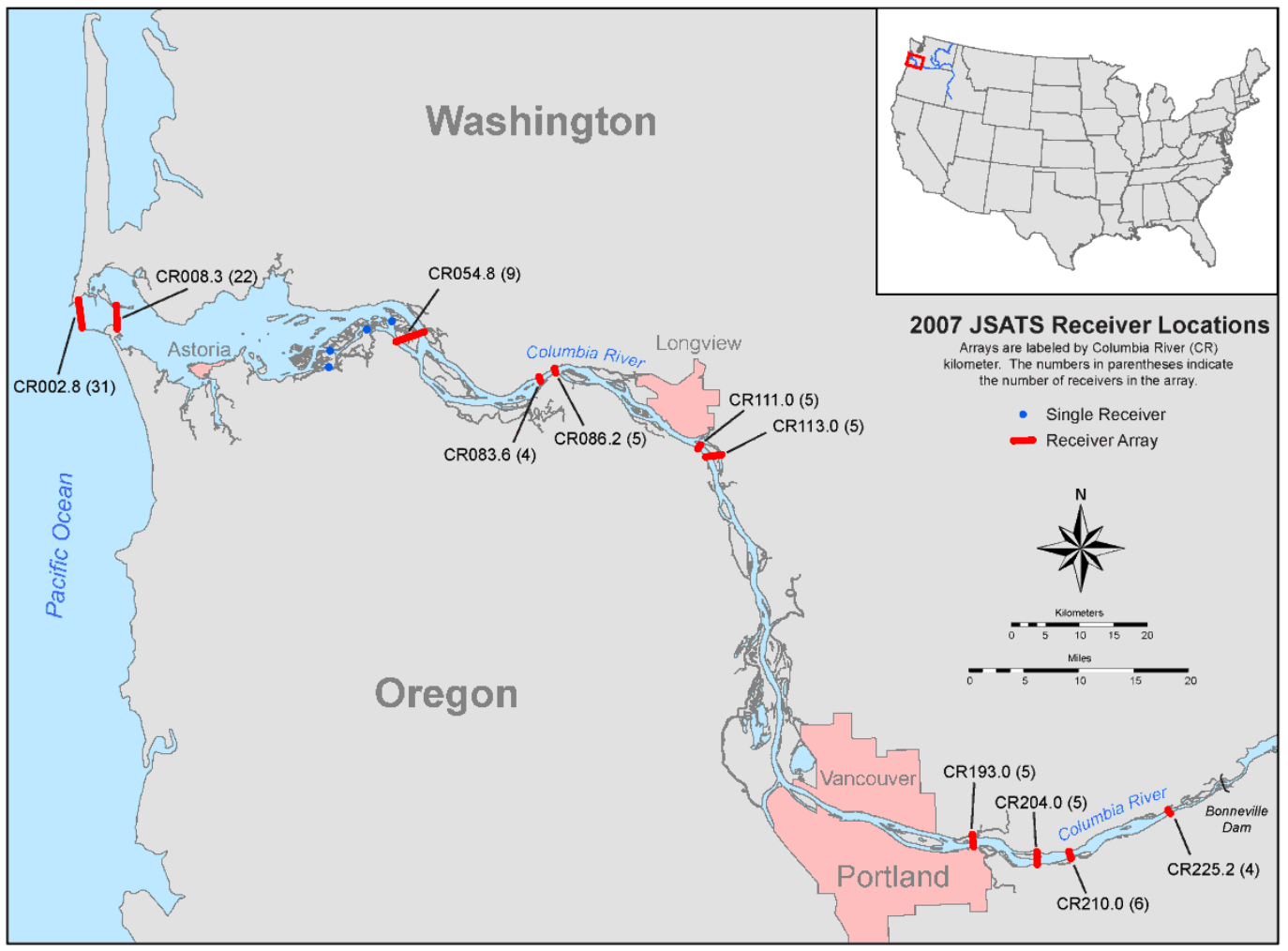

Figure 3.4. JSATS acoustic telemetry receivers in the lower Columbia River in 2007. 


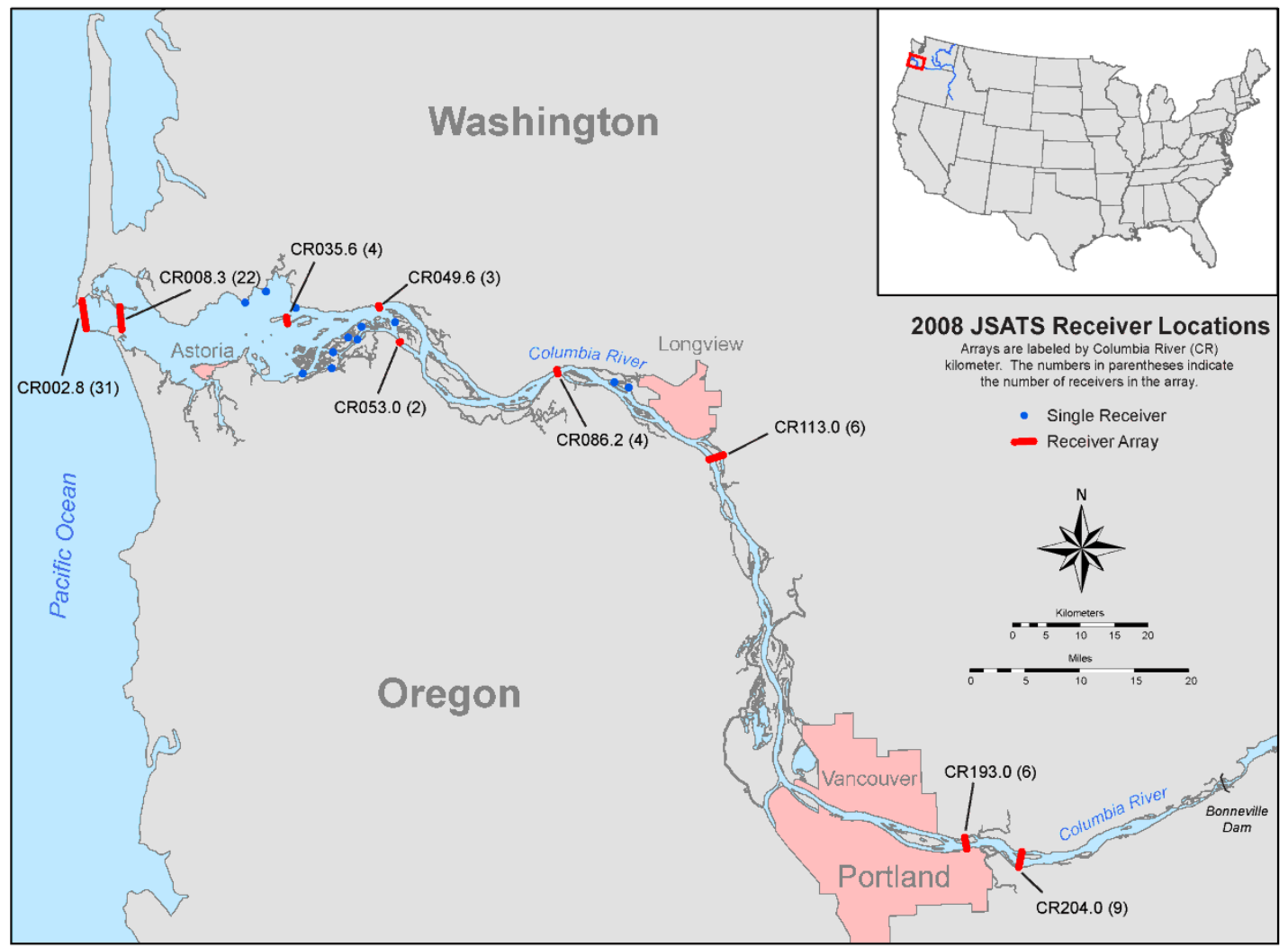

Figure 3.5. JSATS acoustic telemetry receivers in the lower Columbia River in 2008.

Fish from all release locations and groups were pooled for analyses, unless otherwise specified. Acoustic receiving arrays were assigned to one of three sections as seen in Table 3.2. Only one array was present in the main channel in the section of river that includes the estuary islands (CR058.0 in 2007 and CR049.6 in 2008); where appropriate, data from these arrays were combined. Where weekly data are presented, fish were grouped according to Julian date, either by date of release or detection at an array, and dates shown are the middle of the Julian week.

Travel rate of fish tagged with JSATS acoustic transmitters was calculated as the time of first detection at an upstream array (or time of release) to time of first detection at the downstream array, divided by the distance between the arrays. For the section between Bonneville Dam and Vancouver, travel rates were calculated for all fish detected at an array near Kalama, Washington (CR113.0), that were either released at Bonneville Dam or released upstream of Bonneville Dam and detected at any of the Bonneville tailrace arrays (CR225.2 through CR193.0). For the lower CR section, travel rates were calculated for fish detected at CR113.0 and CR008.3. For the MCR, travel rates were calculated for fish detected at CR008.3 and CR002.8.

Hourly presence of fish tagged with JSATS acoustic transmitters at arrays downstream of Bonneville Dam was analyzed for influence of release time, based on release location. It was determined that time of release at Bonneville Dam influenced the hourly distribution of fish at arrays all the way down to CR008.3. For fish released upstream of Bonneville Dam (including fish released into the tailrace of The 
Dalles Dam), release time did not appear to influence hourly distribution at arrays downstream from Bonneville Dam. Therefore, only fish released upstream of Bonneville Dam were used for the remainder of the hourly distribution analyses.

Hourly fish presence was also analyzed by release week to determine whether the hourly distribution of fish changed throughout the migration season. Release week did not appear to impact hourly distributions of fish at arrays downstream from Bonneville Dam; therefore, fish were pooled across all release dates.

All fish released upstream of Bonneville Dam were grouped according to species and run type and were counted as present for each hour during which they were detected at an array, independent of day, release group, or release location. The number of fish present during each hour was divided by the total across all 24 hours to get the percentage for each hour. The hours of approximate darkness shown in the figures are from one hour after sunset to one hour prior to sunrise, Pacific Standard Time, on the middle day of the season for each run type, at a location in the middle of the analyzed section of river (Longview, Washington).

To evaluate relationships between detections of JSATS-tagged fish and tides, a count of first time detections for fish from each species and run type was made over five-minute intervals. Using the tide generating software WXTIDE32 (http://www.wxtide32.com/), we produced tide elevation plots for periods during which tagged fish were migrating past the primary detection array. Counts of detections were then plotted against the change in tide, as was the percentage of time the tide was at each stage.

Use of migration pathways outside the main river channel was analyzed in the context of detection at an upstream array, or entrance array. This was done because not all sections had coverage across the entire width of the river. In some cases, as in 2008 at the estuary islands, the main channel array (Three-Tree Point) was located several kilometers downstream of the channel division where fish might enter the islands (Clifton Channel), and other channels and routes occurred in between. Therefore, the percentages shown are the number of fish detected along a particular route, divided by the number of fish detected at the closest upstream array that detected fish across the entire river channel. In addition, not all fish that were detected at the entrance array could be assigned to a route at the area of interest. This is due to a number of factors, including mortality, detection probabilities that were less than $100 \%$, the existence of routes that were not monitored by detection equipment, and potential residualization. Therefore, the sum of the percentages of fish detected in the main channel and side channel do not equal $100 \%$.

Cross-channel distribution was analyzed for the two arrays nearest the Pacific Ocean. Fish were counted at each receiver position at which they were detected, and the total number of fish at each position was divided by the total across the array to obtain the percentage of fish present at each location. This provided a better picture of which areas the fish used than simply relying on first detections at the array. Receivers were not always in the same places from year to year, so to make comparisons between years possible, the percentage of fish at each position was plotted by distance to a reference point on shore. Data from the autonomous receivers on the array at CR008.3 in 2005 were combined with data from the cabled-array receiver downstream. The Appendix to this report contains a list of the latitudes and longitudes for the receiver locations and reference points, as well as calculated distances for each receiver location. At array CR002.8, there were periods during which receivers were located in the 
navigation channel. These periods were analyzed separately to determine the percentage of fish migrating in the navigation channel.

Fish tagged with JSATS acoustic tags were tracked by NOAA Fisheries using a mobile threedimensional positioning system beginning in 2007. Obtaining information on fish depth was not the primary objective of the mobile tracking effort, and a study designed specifically to gather depth information would result in more reliable estimates of depth. However, it was possible to generate depth estimates using the data collected in 2007. Data collected in 2008 are still being analyzed. To obtain a depth estimate on a fish, a single ping from the tag had to be detected and properly decoded by all four hydrophones aboard the tracking vessel. Depth estimates were not generated for fish that were estimated

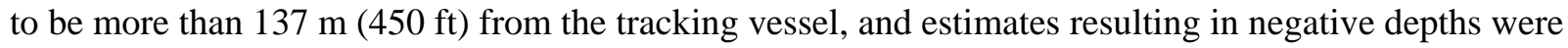
removed from the analyses. In addition, depth estimates from fish that appeared to be stationary (dead) were omitted. Estimates were grouped by species and run type, and location of the fish, based on the origin of the track.

\subsection{Migratory Behavior Data Summary}

For yearling Chinook salmon, the slowest travel rate occurred in the section between Vancouver and East Sand Island. The fastest travel rate occurred in the MCR area (Table 3.3). Subyearling Chinook salmon and steelhead also exhibit the same pattern of having the fastest travel rate in the MCR and slowest travel rate in the lower CR section (Tables 3.4 and 3.5). It is also interesting to note that travel rates in the MCR have consistently increased each year for both species over the last 4 years.

Table 3.3. Travel rates for yearling Chinook salmon between each of three sections of the Columbia River downstream of Bonneville Dam, 2005 through 2008.

\begin{tabular}{ccccc}
\hline CH1 & Year & $\mathrm{N}$ & $\begin{array}{c}\text { Mean (SE) } \\
\text { km/day }\end{array}$ & $\begin{array}{c}\text { Median } \\
\text { km/day }\end{array}$ \\
\hline \multirow{3}{*}{ MCR } & 2005 & 95 & $104.9(6.7)$ & 104.2 \\
& 2006 & 873 & $128.9(2.4)$ & 137.5 \\
& 2007 & 1455 & $136.8(1.9)$ & 149.0 \\
& 2008 & 2952 & $142.3(1.2)$ & 151.7 \\
Lower CR & 2005 & NA & NA & NA \\
& 2006 & NA & NA & NA \\
& 2007 & 2966 & $57.6(0.2)$ & 60.5 \\
Vancouver to & 2008 & 3424 & $60.7(0.5)$ & 63.6 \\
Bonneville & 2005 & NA & NA & NA \\
& 2006 & NA & NA & 82.1 \\
& 2007 & 4915 & $76.1(0.2)$ & 82.1 \\
\hline
\end{tabular}


Further breaking down the section between Vancouver and East Sand Island, travel rates consistently slowed down between each array as the fish move downstream, with the slowest rate between CR049.6 and CR008.3. This is true for yearling Chinook salmon (Table 3.6), subyearling Chinook salmon (Table 3.7), and steelhead (Table 3.8). Between those two arrays, the river channel widens after the river passes through the Coastal Range and becomes more complex, with many shallow areas and islands between channels. Further, the tidal influence over river velocities in the lower $50 \mathrm{~km}$ of river is greater than farther upstream.

All species exhibit a slight increase in travel rate throughout the season through all sections of the river, with the possible exception of the MCR (Figures 3.6 through 3.8).

Table 3.4. Travel rates for subyearling Chinook salmon between each of three sections of the Columbia River downstream of Bonneville Dam, 2005 through 2008. Too few data points existed to calculate travel rate in 2004.

\begin{tabular}{ccccc}
\hline CH0 & Year & $\mathrm{N}$ & $\begin{array}{c}\text { Mean (SE) } \\
(\mathrm{km} / \text { day })\end{array}$ & $\begin{array}{c}\text { Median } \\
(\mathrm{km} / \text { day })\end{array}$ \\
\hline \multirow{3}{*}{ MCR } & 2005 & 135 & $72.0(6.0)$ & 54.2 \\
& 2006 & 1133 & $93.4(1.9)$ & 96.0 \\
& 2007 & 1944 & $85.7(1.7)$ & 79.7 \\
& 2008 & 3683 & $97.2(1.2)$ & 98.9 \\
Lower CR & 2005 & NA & NA & NA \\
& 2006 & NA & NA & NA \\
& 2007 & 2728 & $40.8(0.2)$ & 42.0 \\
Vancouver to & 2008 & NA & NA & NA \\
Bonneville & 2005 & NA & NA & NA \\
& 2006 & NA & NA & 65.3 \\
& 2007 & 4899 & $64.3(0.2)$ & NA \\
\hline
\end{tabular}

Table 3.5. Travel rates for steelhead between each of three sections of the Columbia River downstream of Bonneville Dam, 2005 through 2008

\begin{tabular}{ccccc}
\hline STL & Year & $\mathrm{N}$ & $\begin{array}{c}\text { Mean (SE) } \\
(\mathrm{km} / \text { day })\end{array}$ & $\begin{array}{c}\text { Median } \\
(\mathrm{km} / \text { day })\end{array}$ \\
\hline \multirow{2}{*}{ MCR } & 2005 & 28 & $104.9(15.6)$ & 92.2 \\
& 2008 & 847 & $150.5(2.4)$ & 159.4 \\
Lower CR & 2005 & NA & NA & NA \\
& 2008 & 966 & $76.8(0.5)$ & 76.6 \\
Vancouver to & 2005 & NA & NA & NA \\
Bonneville & 2008 & 1739 & $97.0(0.5)$ & 97.9 \\
\hline
\end{tabular}


Table 3.6. Travel rate in kilometers per day for yearling Chinook salmon from first detection at the upstream array to first detection at the downstream array, for three sections in the lower Columbia River between Vancouver and East Sand Island.

\begin{tabular}{ccccc}
\hline CH1 & Year & $\mathrm{N}$ & $\begin{array}{c}\text { Mean (SE) } \\
(\mathrm{km} / \text { day })\end{array}$ & $\begin{array}{c}\text { Median } \\
\text { (km/day) }\end{array}$ \\
\hline \multirow{2}{*}{ CR049.6 to CR008.3 } & 2007 & 2420 & $45.4(0.2)$ & 47.8 \\
& 2008 & 2675 & $45.4(0.2)$ & 45.1 \\
\multirow{2}{*}{ CR086.2 to CR049.6 } & 2007 & 3298 & $75.8(0.5)$ & 75.8 \\
& 2008 & 2238 & $75.1(0.5)$ & 75.8 \\
CR113.0 to CR086.2 & 2007 & 4149 & $89.3(0.2)$ & 90.2 \\
& 2008 & 2972 & $88.6(0.5)$ & 91.2 \\
\hline
\end{tabular}

Table 3.7. Travel rate in kilometers per day for subyearling Chinook salmon from first detection at the upstream array to first detection at the downstream array, for three sections in the lower Columbia River between Vancouver and East Sand Island

\begin{tabular}{ccccc}
\hline CH0 & Year & $\mathrm{N}$ & $\begin{array}{c}\text { Mean (SE) } \\
\text { (km/day) }\end{array}$ & $\begin{array}{c}\text { Median } \\
\text { (km/day) }\end{array}$ \\
\hline \multirow{2}{*}{ CR049.6 to CR008.3 } & 2007 & 1699 & $32.4(0.2)$ & 32.9 \\
& 2008 & 3039 & $41.5(0.2)$ & 41.5 \\
\multirow{2}{*}{ CR086.2 to CR049.6 } & 2007 & 2682 & $52.6(0.2)$ & 51.1 \\
& 2008 & 3021 & $72.7(0.2)$ & 73.0 \\
CR113.0 to CR086.2 & 2007 & 4550 & $65.3(0.2)$ & 62.4 \\
& 2008 & NA & NA & NA \\
\hline
\end{tabular}

Table 3.8. Travel rate in kilometers per day for steelhead from first detection at the upstream array to first detection at the downstream array, for three sections in the lower Columbia River between Vancouver and East Sand Island

\begin{tabular}{ccccc}
\hline STL & Year & $\mathrm{N}$ & $\begin{array}{c}\text { Mean (SE) } \\
(\mathrm{km} / \text { day })\end{array}$ & $\begin{array}{c}\text { Median } \\
(\mathrm{km} / \text { day })\end{array}$ \\
\hline CR049.6 to CR008.3 & 2008 & 727 & $56.6(0.5)$ & 55.4 \\
CR086.2 to CR049.6 & 2008 & 660 & $97.0(1.0)$ & 97.4 \\
CR113.0 to CR086.2 & 2008 & 924 & $110.4(0.7)$ & 108.7 \\
\hline
\end{tabular}



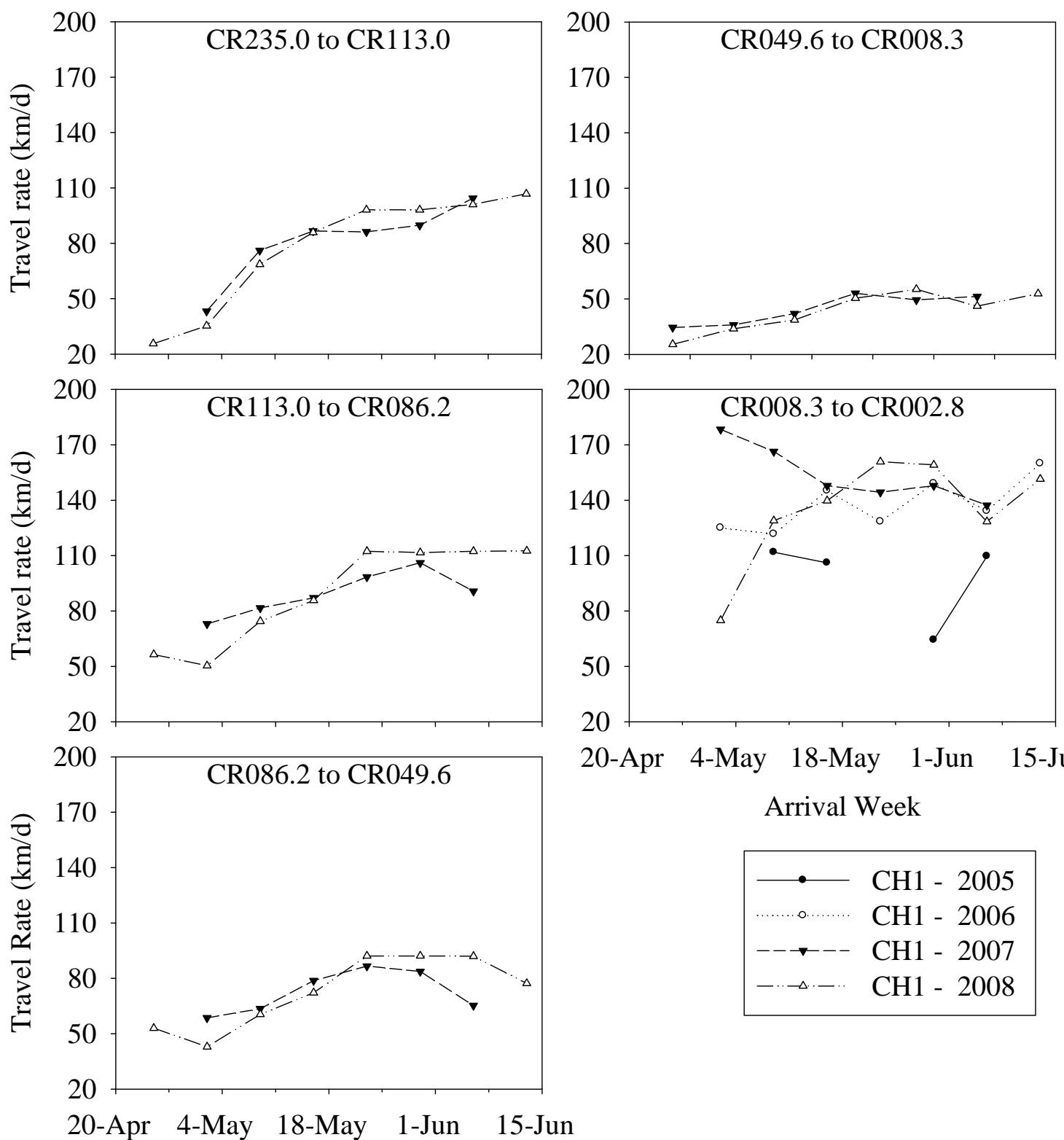

20-Apr 4-May 18-May 1-Jun 15-Jun Arrival Week

$$
\begin{aligned}
& \longrightarrow \quad \mathrm{CH} 1-2005 \\
& \text { …........... CH1 - } 2006 \\
& \rightarrow-\rightarrow \text { CH1 - } 2007 \\
& \rightarrow-\cdots \quad \text { CH1 - } 2008
\end{aligned}
$$

\section{Arrival Week}

Figure 3.6. Weekly median travel rates of yearling Chinook salmon between acoustic receiving arrays in the Columbia River downstream of Bonneville Dam, 2005 through 2008. 

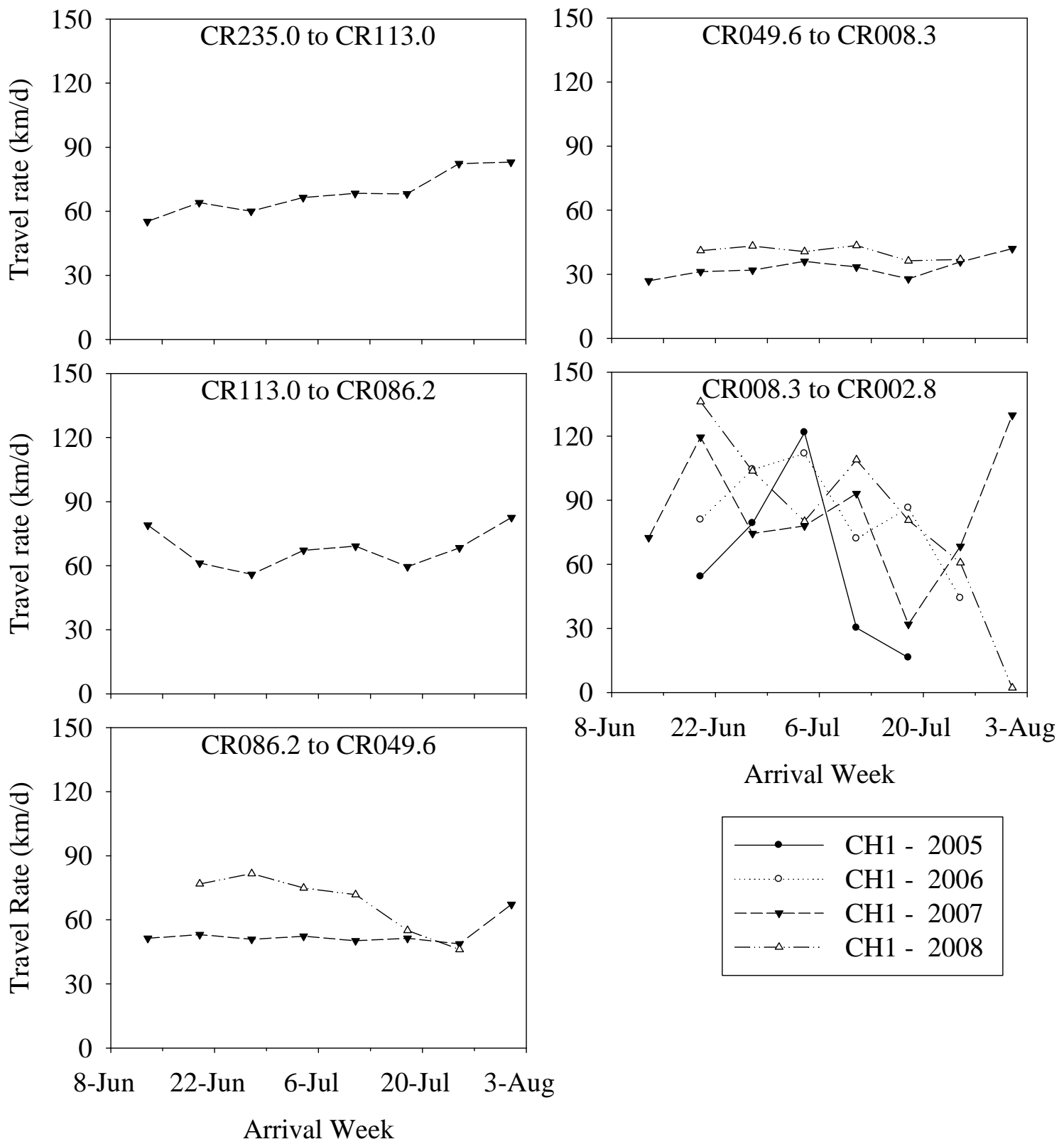

Arrival Week

$$
\begin{array}{|cc|}
\hline \bullet & \text { CH1 - } 2005 \\
\cdots \cdots \cdots & \text { CH1 - } 2006 \\
-\cdots-- & \text { CH1 - } 2007 \\
-\cdots-\cdots & \text { CH1 - } 2008 \\
\hline
\end{array}
$$

Figure 3.7. Weekly median travel rates of subyearling Chinook salmon between acoustic receiving arrays in the Columbia River downstream of Bonneville Dam, 2005 through 2008. 

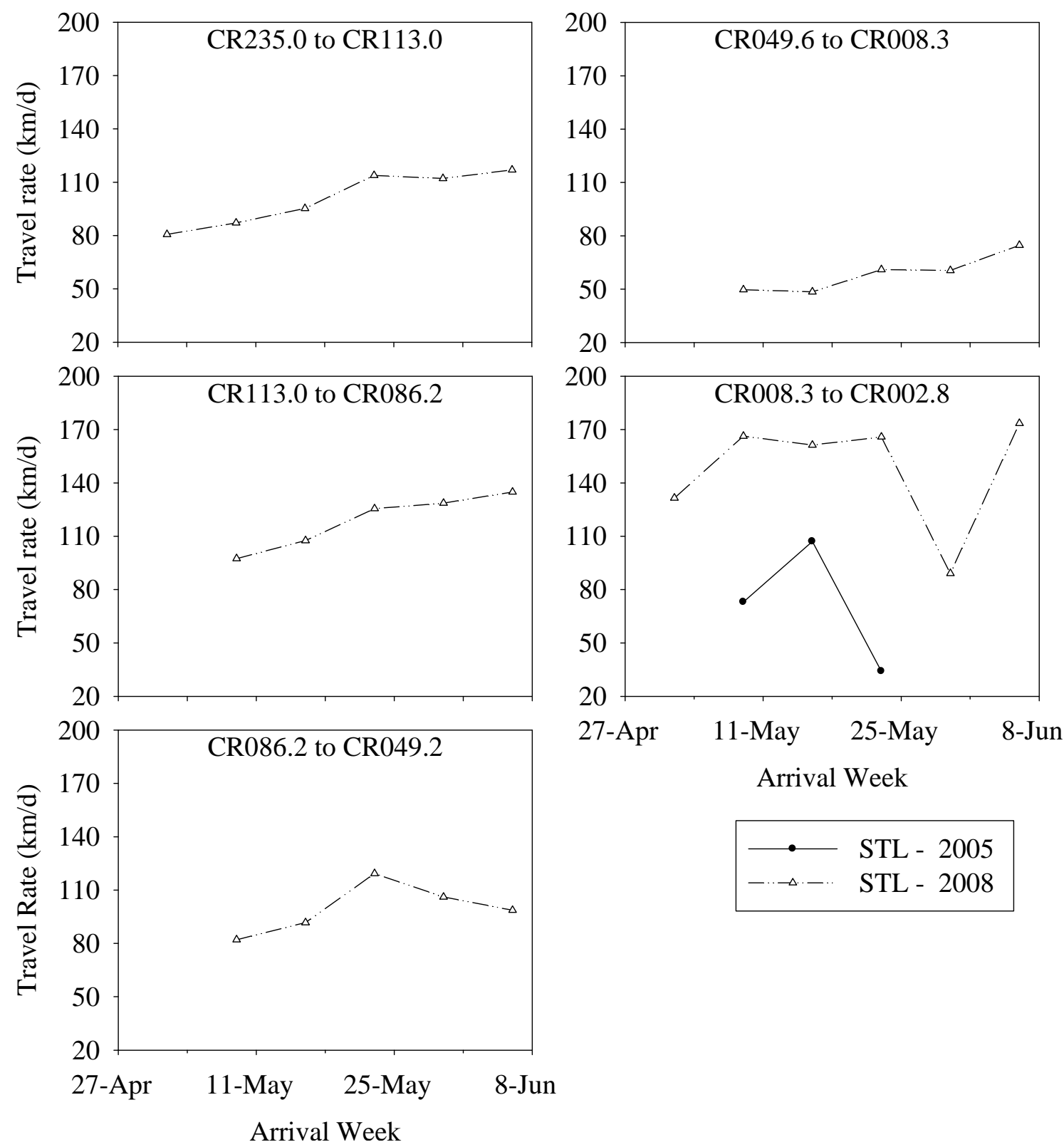

Arrival Week

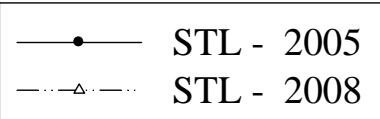

Figure 3.8. Weekly median travel rates of steelhead between acoustic receiving arrays in the Columbia River downstream of Bonneville Dam, 2005 and 2008.

The time of day when acoustic tagged fish were present in the river downstream of Bonneville Dam was related to the time of day when the fish were released, especially for those fish released at Bonneville Dam. Figure 3.9 shows that fish released well upstream of Bonneville Dam, at Lower Granite Dam in this case, which had to travel through several reservoirs and dams prior to being detected, were present nearly equally during all hours of the day, while the effect of the release times of fish released at Bonneville Dam was detected in their hourly distributions all the way down to RKM 8. Therefore, for the remainder of the time-of-day analyses, only the data from fish released well upstream of Bonneville Dam were used; no data are presented for 2004 and 2005 because all fish in those years were released at or downstream of Bonneville Dam. 

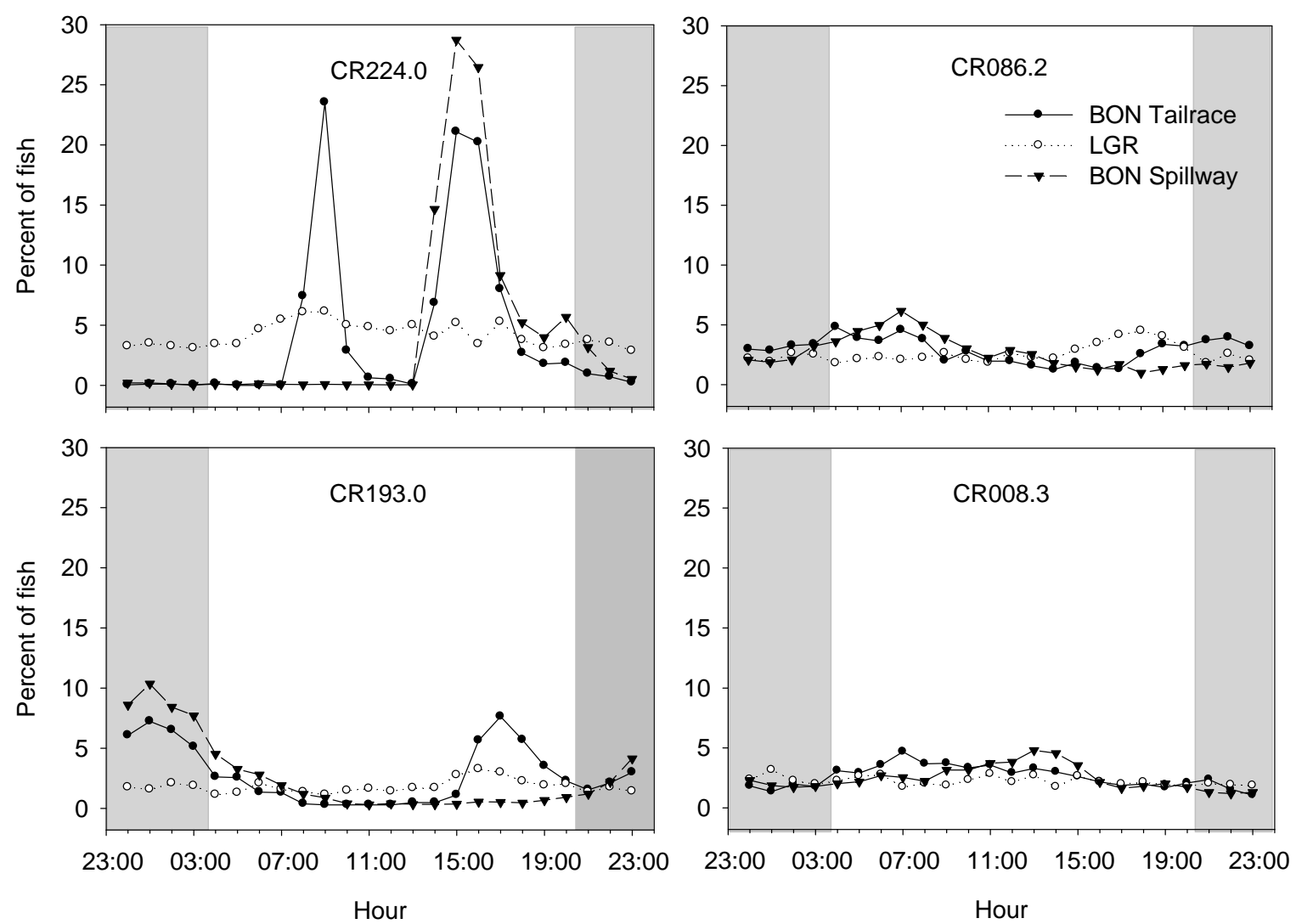

Figure 3.9. Yearling Chinook salmon released at Bonneville Dam in the tailrace and in the spillway and yearling Chinook salmon released downstream of Lower Granite Dam (LGR) in 2007 and the effect of release time on presence during each hour of the day. Each panel shows the hourly distribution at one of four detection arrays in the lower Columbia River. Grey areas denote approximate hours of darkness.

Throughout the season, fish were present at arrays during all hours of the day (Figure 3.10). In general, yearling Chinook salmon, subyearling Chinook salmon and steelhead were present at all arrays during all hours of the day (Figures 3.11 through 3.13). The spike in percentage of steelhead present at arrays CR204 and CR193 is unrelated to release time; these fish were released at three different times throughout the day in two locations (Arlington and the John Day Dam tailrace).

Yearling Chinook salmon were most often first detected at the array at East Sand Island (CR008.3) on an outgoing (ebb) tide (Figure 3.14). From 2004 to 2008, 76\% to 91\% of yearling Chinook salmon detections occurred during an ebb tide at East Sand Island. During each of these years, ebb tides occurred about $55 \%$ of the time between the first and last yearling Chinook salmon detection at the East Sand Island array. A similar but weaker pattern was observed for yearling Chinook salmon detected at array CR002.8 (Figure 3.15). From 2005 to 2008, the percentage of yearling Chinook detected on an outgoing tide ranged from $56 \%$ to $82 \%$ and was greater than the percentage of time during which the tide was outgoing, which was about $47 \%$ for all 4 years. The pattern was particularly evident in 2005, 2007, and 2008 when 82, 77, and 75\% of yearling Chinook salmon detections occurred, respectively, during an ebb tide. 


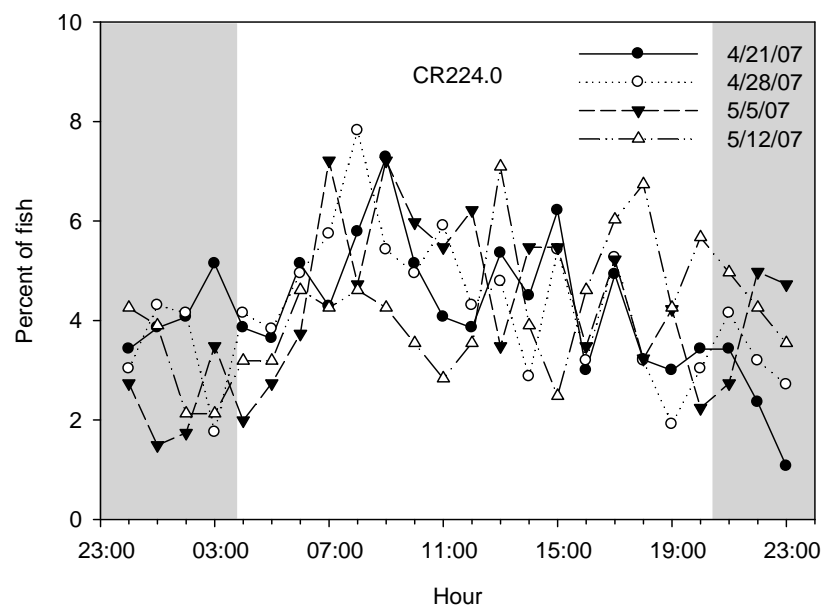

Figure 3.10. Hourly distribution of yearling Chinook salmon released at Lower Granite Dam in 2007 at array CR224.0, downstream of Bonneville Dam, by release week. Grey areas denote approximate hours of darkness.

Subyearling Chinook salmon were even more likely to be detected at array CR008.3 on an outgoing tide (Figure 3.16). From 2005 to 2008, 84\% to 94\% of subyearling Chinook salmon first detections at array CR008.3 occurred during an ebb tide. Ebb tides occurred about 55\% of the time during the period when subyearling Chinook were being detected at array CR008.3. A similar, but weaker pattern was observed for subyearling Chinook salmon detected at array CR002.8 (Figure 3.17). About 56\% to 77\% of first subyearling Chinook salmon detections happened during an ebb tide, which occurred $47 \%$ to $49 \%$ of the time.

Steelhead behaved similarly to both yearling and subyearling Chinook salmon, with a greater percentage of first time detections occurring during outgoing tides at array CR008.3 (Figure 3.18) than at array CR002.8 (Figure 3.19). About $89 \%$ to $91 \%$ of steelhead detections occurred at array CR008.3 during an ebb tide, which occurred $55 \%$ of the time, whereas about $60 \%$ to $76 \%$ of steelhead detections at array CR002.8 occurred during an ebb tide, which accounted for about $47 \%$ of all tides at CR002.8 during the time steelhead were being detected.

All yearling and subyearling Chinook salmon and steelhead used side-channel routes to some extent on their migration to the Pacific Ocean. This was true for all areas in which receivers were deployed in side-channel areas. Side-channel use in the section between Bonneville Dam and CR086.2 ranged from less than $1 \%$ to $3 \%$ of fish detected at an upstream array (Table 3.9 and 3.10). Side-channel use in the section of the lower CR from CR058 through CR029 was greater, ranging from $7 \%$ to $20 \%$, depending on the year and species (Table 3.11). In 2007, there was a temporal trend for yearling Chinook salmon use of the side-channel route at Tenasillahe Island (Clifton Channel). More than $2 \%$ of the fish detected at CR086.2 were detected in Clifton Channel at the beginning of the season and increased to $13 \%$ at the end of the migration season (Table 3.12). Use of Clifton Channel ranged from 5\% to $9 \%$ for yearling Chinook salmon in 2008, with no consistent temporal trend within their migration period. For subyearling Chinook salmon, there was a trend of increasing use of Clifton Channel as the season progressed in 2008, increasing from $7 \%$ at the beginning to $19 \%$ at the end, but there was not a consistent trend in 2007 (Table 3.13). Steelhead use of Clifton Channel was consistent over the season; approximately 7\% of the fish detected at array CR086.2 were detected in this channel (Table 3.14). 

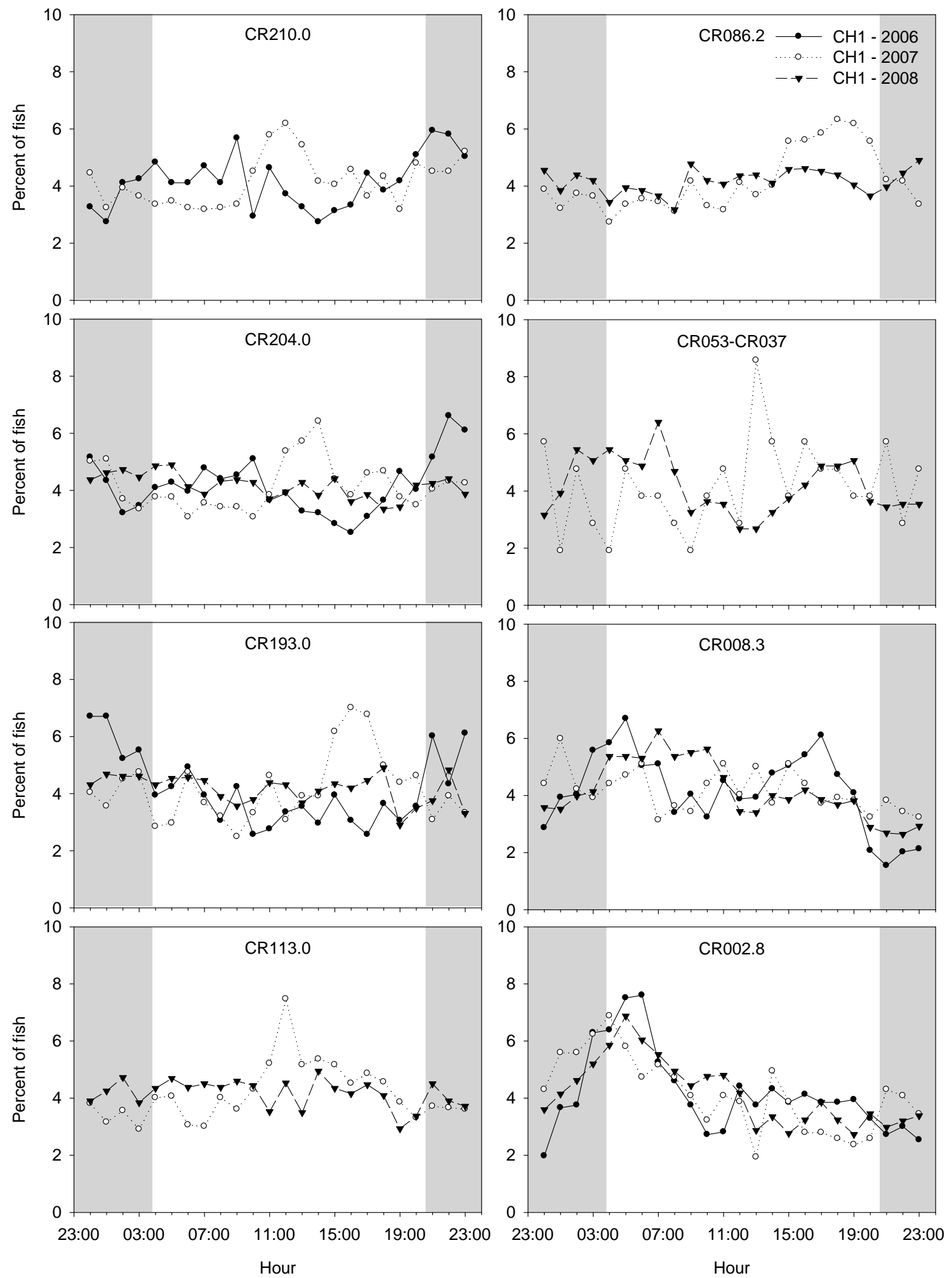

Figure 3.11. Hourly distribution of yearling Chinook salmon released upstream of Bonneville Dam at arrays in the lower Columbia River, 2006-2008. Grey areas denote approximate hours of darkness. 

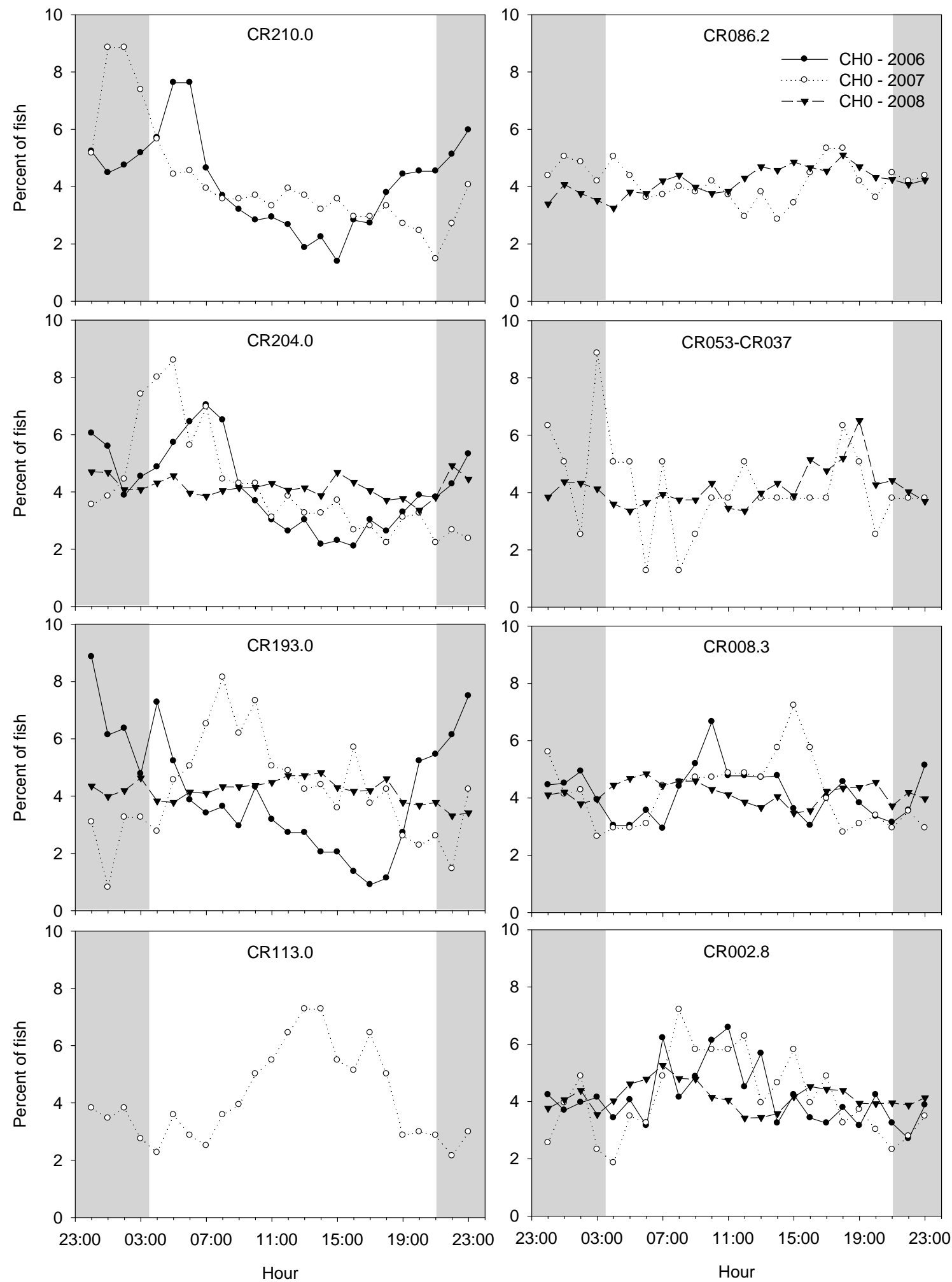

Figure 3.12. Hourly distribution of subyearling Chinook salmon released upstream of Bonneville Dam at arrays in the lower Columbia River, 2006-2008. Grey areas denote approximate hours of darkness. 

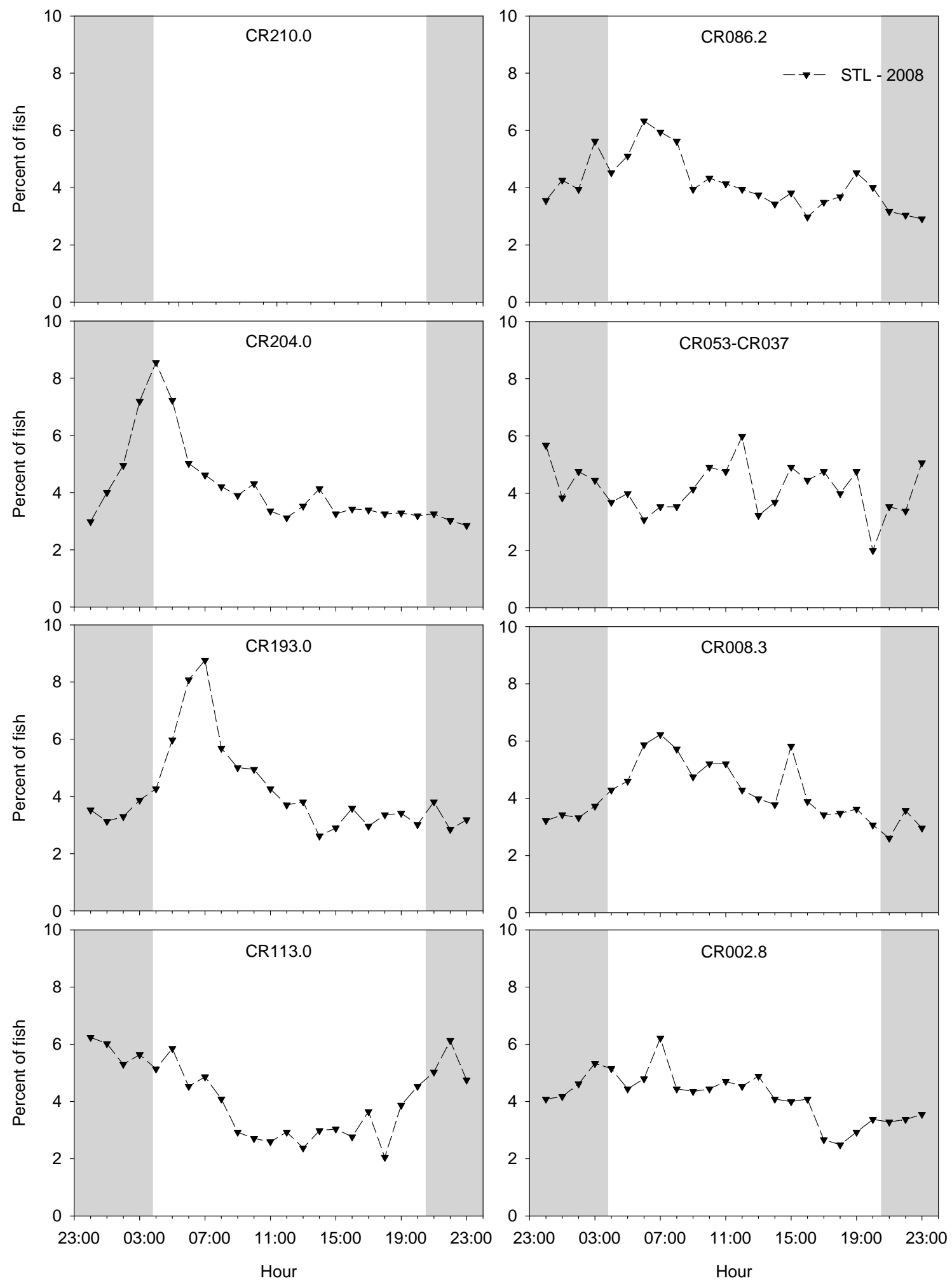

Figure 3.13. Hourly distribution of steelhead released upstream of Bonneville Dam at arrays in the lower Columbia River, 2008. Grey areas denote approximate hours of darkness. No data are presented for array CR210.0 because it was not used in 2008. 


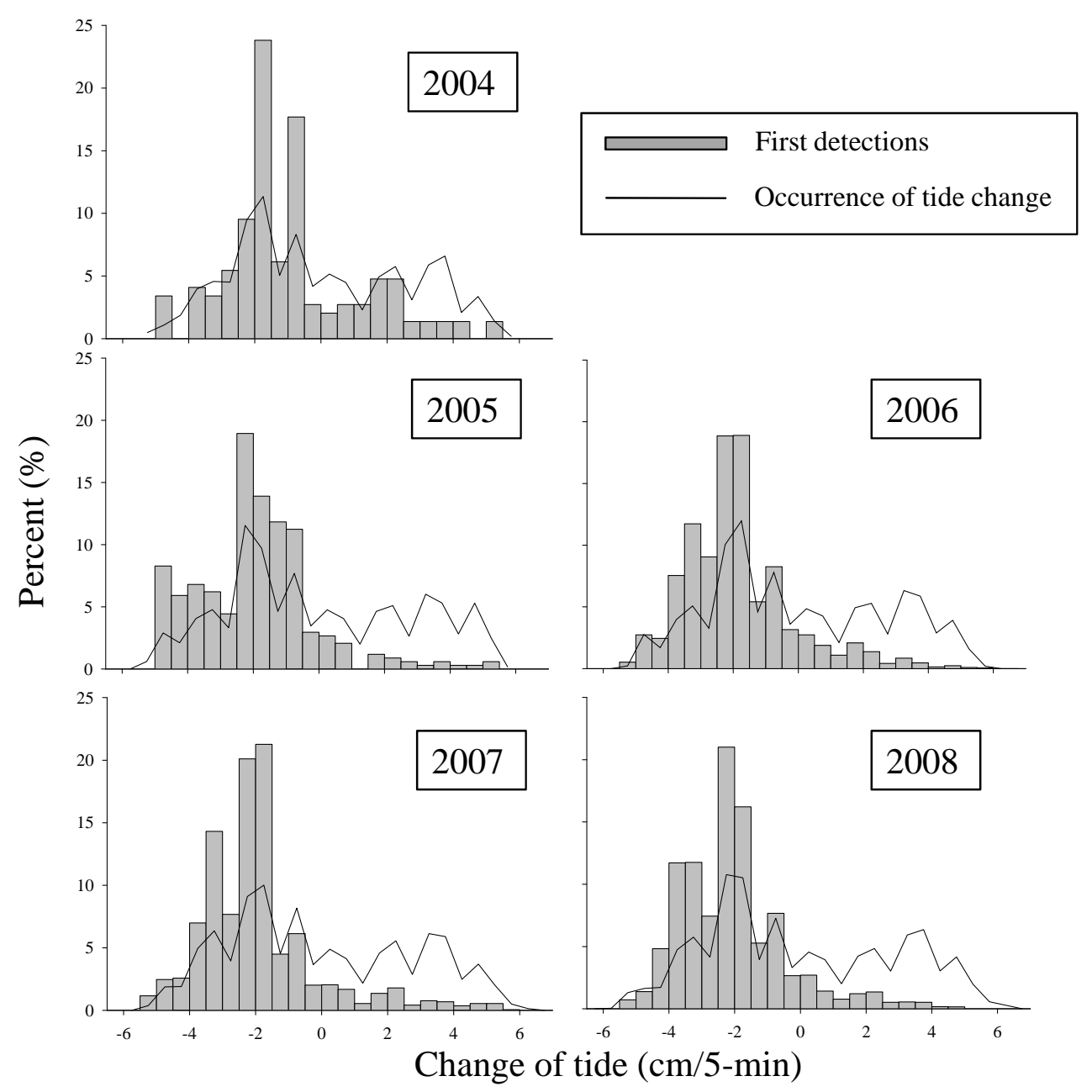

Figure 3.14. Detections of yearling Chinook salmon versus change in tide at CR008.3. Negative values indicate outgoing (ebb) tides; positive values indicate incoming (flood) tides.

At array CR008.3, the distribution of yearling Chinook salmon was skewed toward the northern portion (Washington side) of the array. In 2005, the autonomous receivers ended at the pile dike on the western end of East Sand Island, and the largest proportion of yearling Chinook salmon passed that array near the pile dike (Figure 3.20). At array CR002.8, the cross-channel distribution of yearling Chinook salmon was somewhat more variable, with the largest proportion of first detections near the North Jetty in 2005, near the navigation channel in 2006, and on the south side of the navigation channel in 2007 and 2008 (Figure 3.21). For reference, the receiver closest to the North Jetty was approximately $0.1 \mathrm{~km}$ away in 2005 and $0.2 \mathrm{~km}$ away in 2006 through 2008. In 2005 and 2006, the receiver closest to the South Jetty was more than 1 kilometer away, although in 2007 and 2008 the receiver closest to the South Jetty was approximately $0.2 \mathrm{~km}$ away. For periods during which receivers were in the navigation channel, $4 \%$ to $6 \%$ of the first detections of yearling Chinook salmon occurred on those receivers (Figure 3.22).

The distribution of subyearling Chinook salmon was skewed even farther to the north at array CR008.3 than was the distribution of yearling Chinook salmon (Figure 3.23). Subyearling Chinook salmon were more often first detected on the northern portion of array CR002.8 (Figure 3.24), and this 
trend was consistent across the years. For periods during which acoustic receivers were in the navigation channel, $3 \%$ to $6 \%$ of first detections of subyearling Chinook salmon occurred on those receivers

(Figure 3.25).

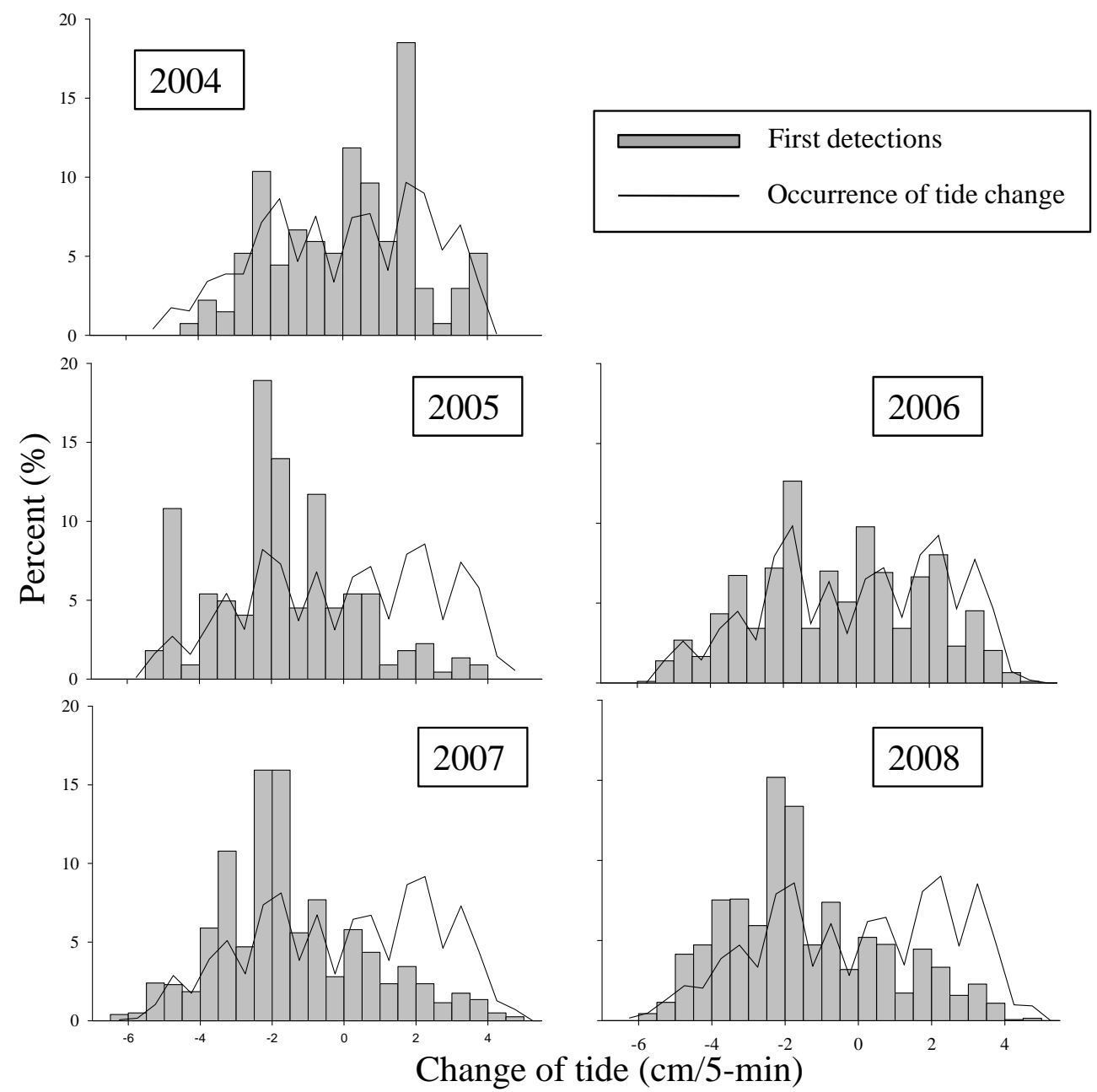

Figure 3.15. Detections of yearling Chinook salmon versus change in tide at CR002.8. Negative values indicate outgoing (ebb) tides; positive values indicate incoming (flood) tides.

The distribution of steelhead at CR008.3 was skewed to the south side of the channel in 2005, although steelhead were more evenly distributed across the array in 2008 (Figure 3.26). At array CR002.8, a larger proportion of first detections of steelhead occurred on the northern portion of the array near the North Jetty and near the navigation channel in 2005. In 2008, steelhead were also more evenly distributed across array CR002.8, with more first detections near the navigation channel (Figure 3.27). For periods when there were acoustic receivers in the navigation channel, $3 \%$ to $5 \%$ of first detections of steelhead occurred on those receivers (Figure 3.28). The difference in distributions of steelhead between the two years may be due, in part, to release location. About half of the steelhead detected at the arrays in 2005 were released at the Astoria-Megler Bridge, while the remainder were released at Skamania Landing. Releasing the fish at the Astoria-Megler Bridge precluded those fish from opting to take the northern route through Grays Bay down to the array at East Sand Island. 


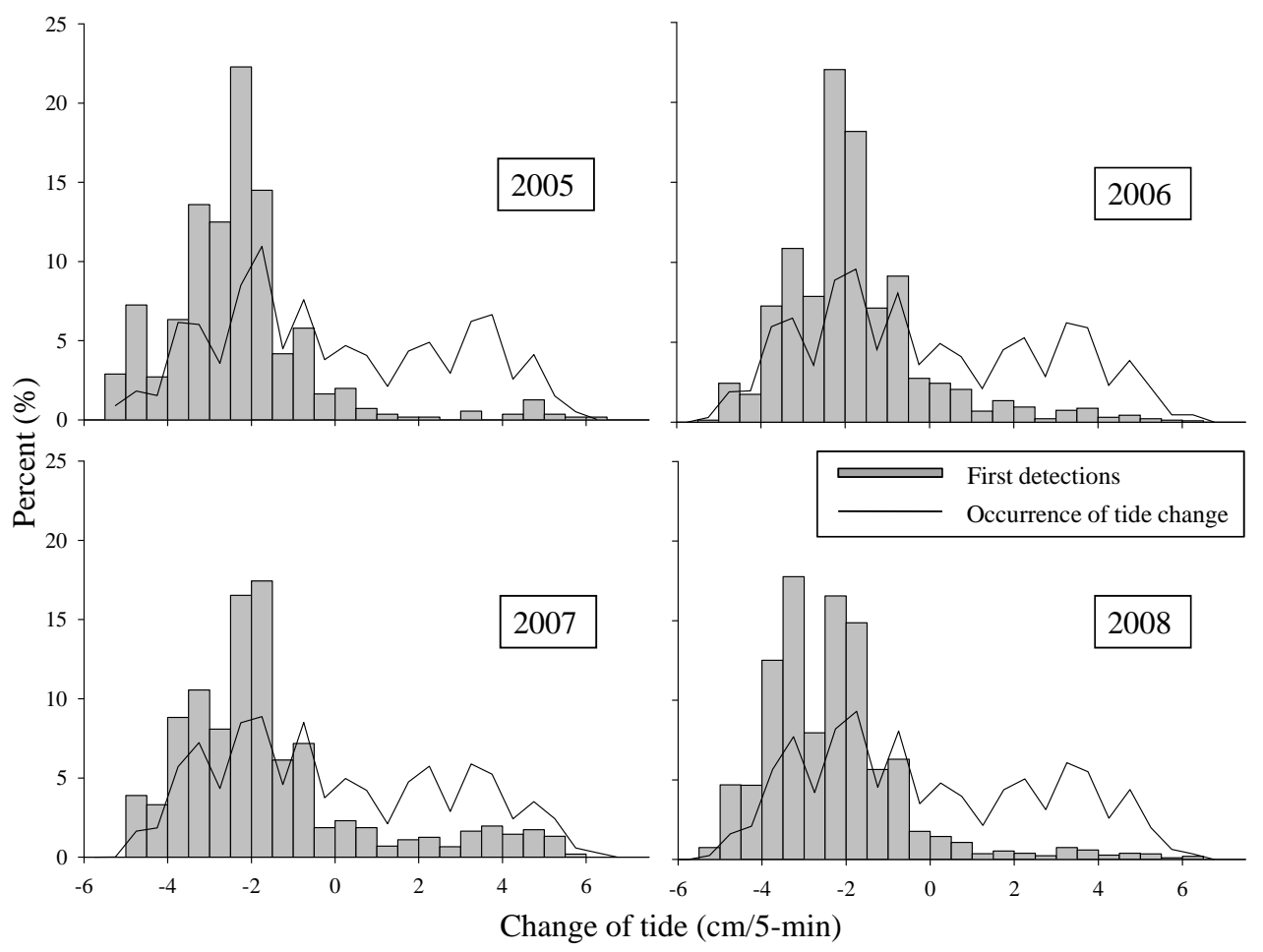

Figure 3.16. Detections of subyearling Chinook salmon versus change in tide at CR008.3. Negative values indicate outgoing (ebb) tides; positive values indicate incoming (flood) tides.

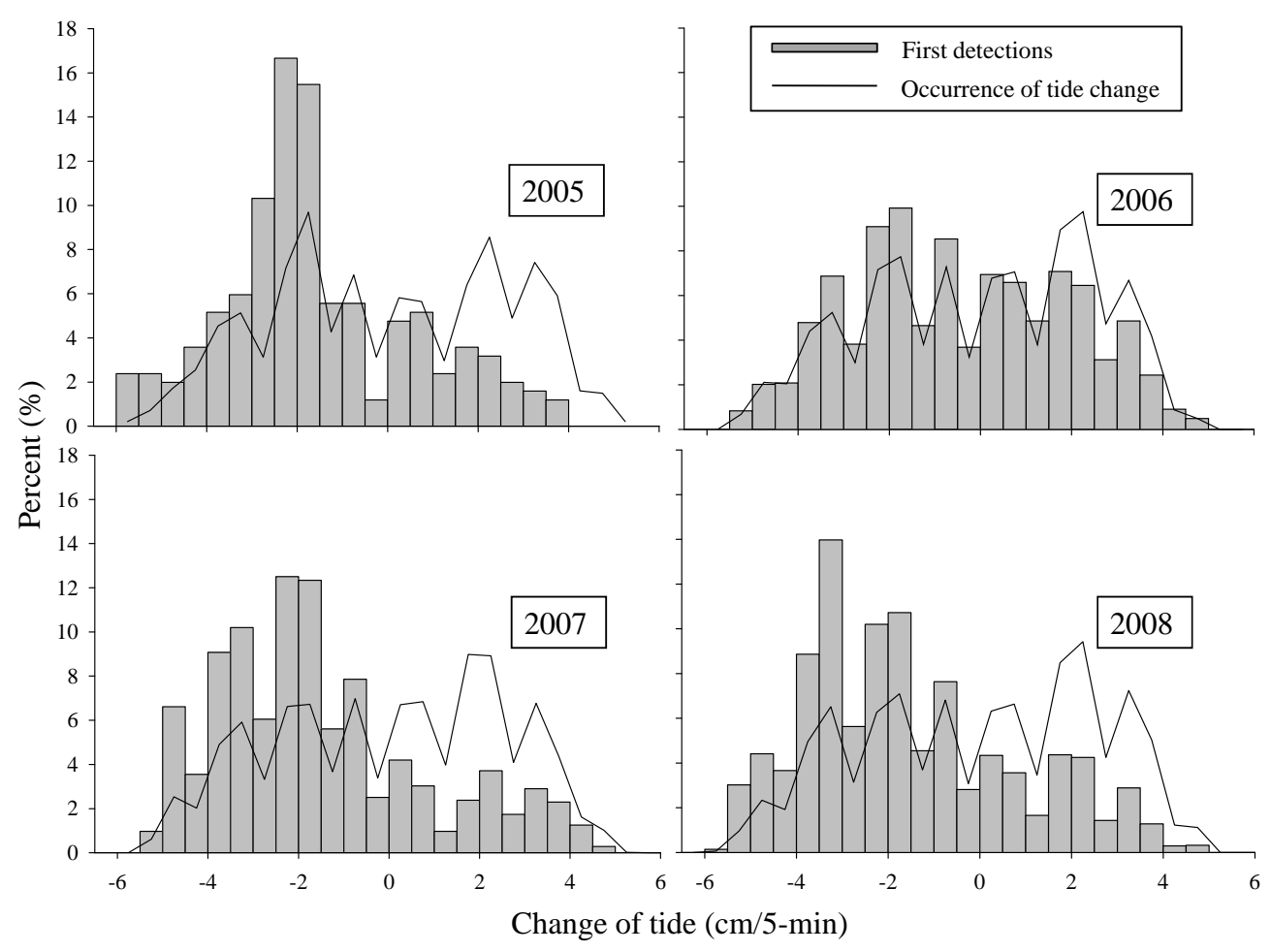

Figure 3.17. Detections of subyearling Chinook salmon versus change in tide at CR002.8. Negative values indicate outgoing (ebb) tides; positive values indicate incoming (flood) tides. 


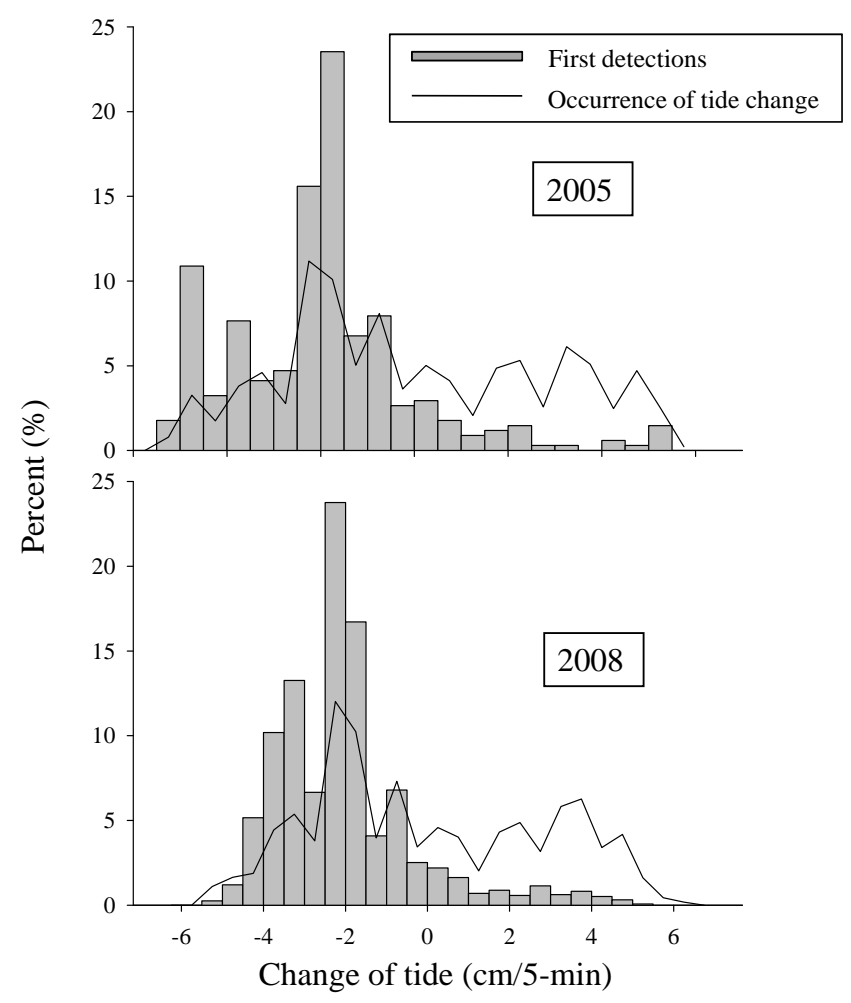

Figure 3.18. Detections of steelhead versus change in tide at CR008.3. Negative values indicate outgoing (ebb) tides; positive values indicate incoming (flood) tides.

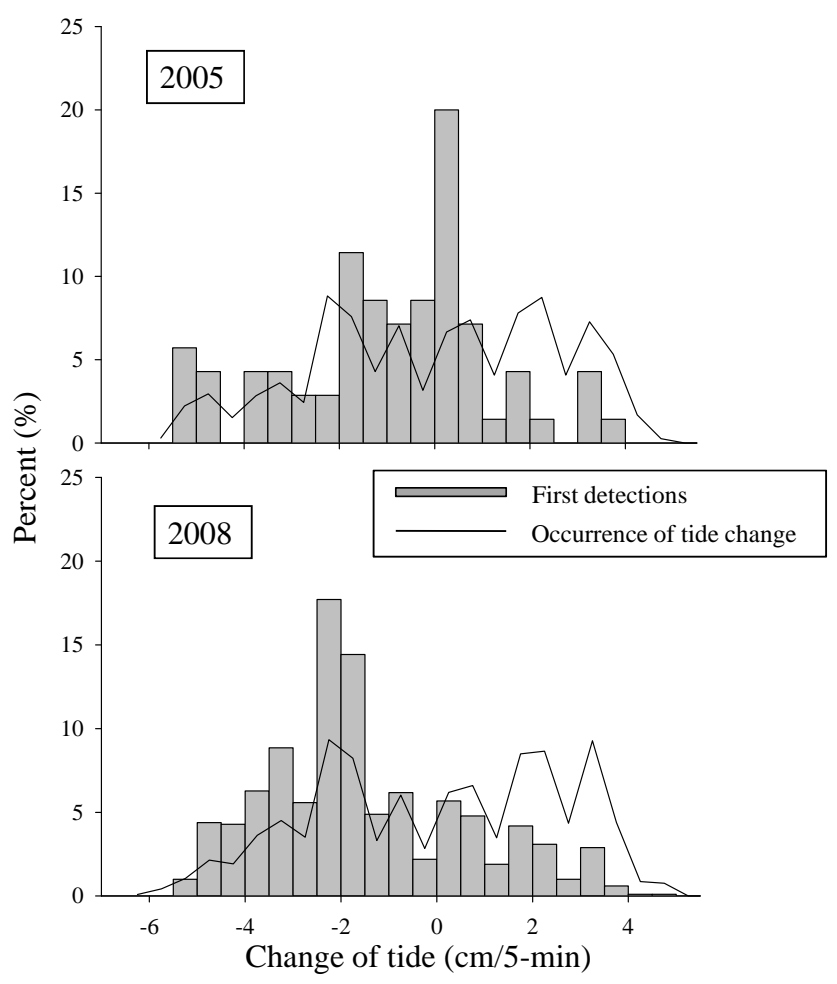

Figure 3.19. Detections of steelhead versus change in tide at CR002.8. Negative values indicate outgoing (ebb) tides; positive values indicate incoming (flood) tides. 
Table 3.9. Numbers of fish detected at CR237.0, CR224.0, CR210.0 and, of those, numbers and percentages of fish detected at CR204.0 in the main channel or side channel (north of Reed Island), and at CR193.0 in the main channel or side channel (north of Lady Island). The remaining fish were not detected in the main channel or side channel.

\begin{tabular}{|c|c|c|c|c|c|c|}
\hline \multirow[b]{2}{*}{ Species/Run } & \multirow[b]{2}{*}{ Year } & \multirow{2}{*}{$\begin{array}{c}\text { Bonneville } \\
\text { arrays }(\mathrm{N})\end{array}$} & \multicolumn{2}{|c|}{ CR204.0 } & \multicolumn{2}{|c|}{ CR193.0 } \\
\hline & & & Main channel & Side channel & Main channel & Side channel \\
\hline \multirow{3}{*}{ CH1 } & 2006 & 2007 & 1180 (59\%) & $68(3 \%)$ & NA & NA \\
\hline & 2007 & 6203 & 4690 (76\%) & 193 (3\%) & 4032 (65\%) & $26(<0 \%)$ \\
\hline & 2008 & 5648 & 4289 (76\%) & 144 (3\%) & 2480 (44\%) & $56(1 \%)$ \\
\hline \multirow{3}{*}{ CHO } & 2006 & 3292 & 2079 (63\%) & $18(1 \%)$ & NA & NA \\
\hline & 2007 & 6214 & 5560 (89\%) & $35(1 \%)$ & 4959 (80\%) & 118 (2\%) \\
\hline & 2008 & 5110 & 4066 (80\%) & $143(3 \%)$ & 3527 (69\%) & $20(<1 \%)$ \\
\hline STL & 2008 & 3018 & 2461 (82\%) & $36(1 \%)$ & 1662 (55\%) & $12(<1 \%)$ \\
\hline
\end{tabular}

Table 3.10. Numbers of yearling Chinook salmon and steelhead detected at CR113.0 and, of those, the number and percentage detected at CR097.2 or CR095.0 (in the Fisher/Hump Island Slough) in 2008.

\begin{tabular}{ccc}
\hline Species/Run & CR113.0 $(\mathrm{N})$ & CR097.2 or CR095.0 \\
\hline CH1 & 4734 & $95(2 \%)$ \\
STL & 1739 & $7(<1 \%)$ \\
\hline
\end{tabular}

Table 3.11. Numbers of fish detected at CR086.2 and, of those, numbers and percentages of fish detected in the main channel (at and CR058.0 in 2007 and CR049.6 in 2008), anywhere in the estuary islands to the south of the main channel (CR038-CR058) and Harrington Point or Grays Bay to the north of the main channel (CR029-CR037).

\begin{tabular}{cccccc}
\hline \multirow{2}{*}{ Species/Run } & Year & CR086.2 (N) & Main channel & Estuary islands & $\begin{array}{c}\text { Harrington Point or } \\
\text { Grays Bay }\end{array}$ \\
\hline \multirow{2}{*}{ CH1 } & 2007 & 5006 & $3298(66 \%)$ & $438(9 \%)$ & NA \\
& 2008 & 4898 & $2239(46 \%)$ & $395(8 \%)$ & $442(9 \%)$ \\
\multirow{2}{*}{ CH0 } & 2007 & 5001 & $2682(54 \%)$ & $1008(20 \%)$ & NA \\
& 2008 & 4714 & $2740(58 \%)$ & $614(13 \%)$ & $708(15 \%)$ \\
STL & 2008 & 1501 & $660(44 \%)$ & $112(7 \%)$ & $84(6 \%)$ \\
\hline
\end{tabular}


Table 3.12. Yearling Chinook salmon detected in the main channel or side channel (Clifton Channel) at Tenasillahe Island, by week of detection at CR086.2 in 2007 and 2008. The remaining fish were not detected in the main channel or side channel.

\begin{tabular}{ccccc}
\hline \multirow{2}{*}{ Year } & $\begin{array}{c}\text { Week detected at } \\
\text { CR086.2 }\end{array}$ & CR086.2 (N) & Main channel & Clifton Channel \\
\hline $5 / 3$ & 821 & $683(83 \%)$ & $19(2 \%)$ \\
2007 & 1543 & $1013(66 \%)$ & $86(6 \%)$ \\
& $5 / 10$ & 1361 & $707(52 \%)$ & $94(7 \%)$ \\
& $5 / 17$ & 1041 & $749(72 \%)$ & $140(13 \%)$ \\
& $5 / 24$ & 240 & $146(61 \%)$ & $31(13 \%)$ \\
& $5 / 31$ & 149 & $90(60 \%)$ & $8(9 \%)$ \\
& $4 / 27$ & 708 & $392(55 \%)$ & $38(5 \%)$ \\
$5 / 4$ & 1356 & $765(56 \%)$ & $82(6 \%)$ \\
& $5 / 11$ & 1457 & $533(37 \%)$ & $61(6 \%)$ \\
& $5 / 18$ & 1039 & $407(39 \%)$ & $9(5 \%)$ \\
\hline
\end{tabular}

Table 3.13. Subyearling Chinook salmon detected in the main channel or side channel (Clifton Channel) at Tenasillahe Island, by week of detection at CR086.2 in 2007 and 2008. The remaining fish were not detected in the main channel or side channel.

\begin{tabular}{ccccc}
\hline Year & $\begin{array}{c}\text { Week detected at } \\
\text { CR086.2 }\end{array}$ & CR086.2 (N) & Main channel & Clifton Channel \\
\hline $6 / 12$ & 151 & $90(60 \%)$ & $26(17 \%)$ \\
$6 / 19$ & 776 & $585(75 \%)$ & $108(14 \%)$ \\
$6 / 26$ & 1065 & $312(29 \%)$ & $227(21 \%)$ \\
& $7 / 3$ & 1346 & $808(60 \%)$ & $213(16 \%)$ \\
& $7 / 10$ & 1151 & $584(51 \%)$ & $229(20 \%)$ \\
$7 / 17$ & 398 & $285(72 \%)$ & $49(12 \%)$ \\
& $>7 / 23$ & 114 & $18(16 \%)$ & $11(10 \%)$ \\
& $6 / 16$ & 537 & $299(56 \%)$ & $37(7 \%)$ \\
$6 / 23$ & 1058 & $635(60 \%)$ & $85(8 \%)$ \\
$6 / 30$ & 914 & $475(52 \%)$ & $56(6 \%)$ \\
& $7 / 6$ & 1203 & $775(64 \%)$ & $178(15 \%)$ \\
& $7 / 13$ & 921 & $514(56 \%)$ & $178(19 \%)$ \\
& $>7 / 19$ & 81 & $42(52 \%)$ & $15(19 \%)$ \\
\hline
\end{tabular}


Table 3.14. Subyearling Chinook salmon detected in the main channel or side channel (Clifton Channel) at Tenasillahe Island, by week of detection at CR086.2 in 2008. The remaining fish were not detected in the main channel or side channel.

\begin{tabular}{ccccc}
\hline \multirow{2}{*}{ Year } & $\begin{array}{c}\text { Week detected at } \\
\text { CR086.2 }\end{array}$ & CR086.2 (N) & Main channel & Clifton Channel \\
\hline \multirow{3}{*}{2008} & $5 / 6$ & 514 & $241(47 \%)$ & $34(7 \%)$ \\
& $5 / 13$ & 491 & $243(49 \%)$ & $36(7 \%)$ \\
& $5 / 20$ & 269 & $105(39 \%)$ & $19(7 \%)$ \\
& $>5 / 26$ & 227 & $71(31 \%)$ & $9(4 \%)$ \\
\hline
\end{tabular}

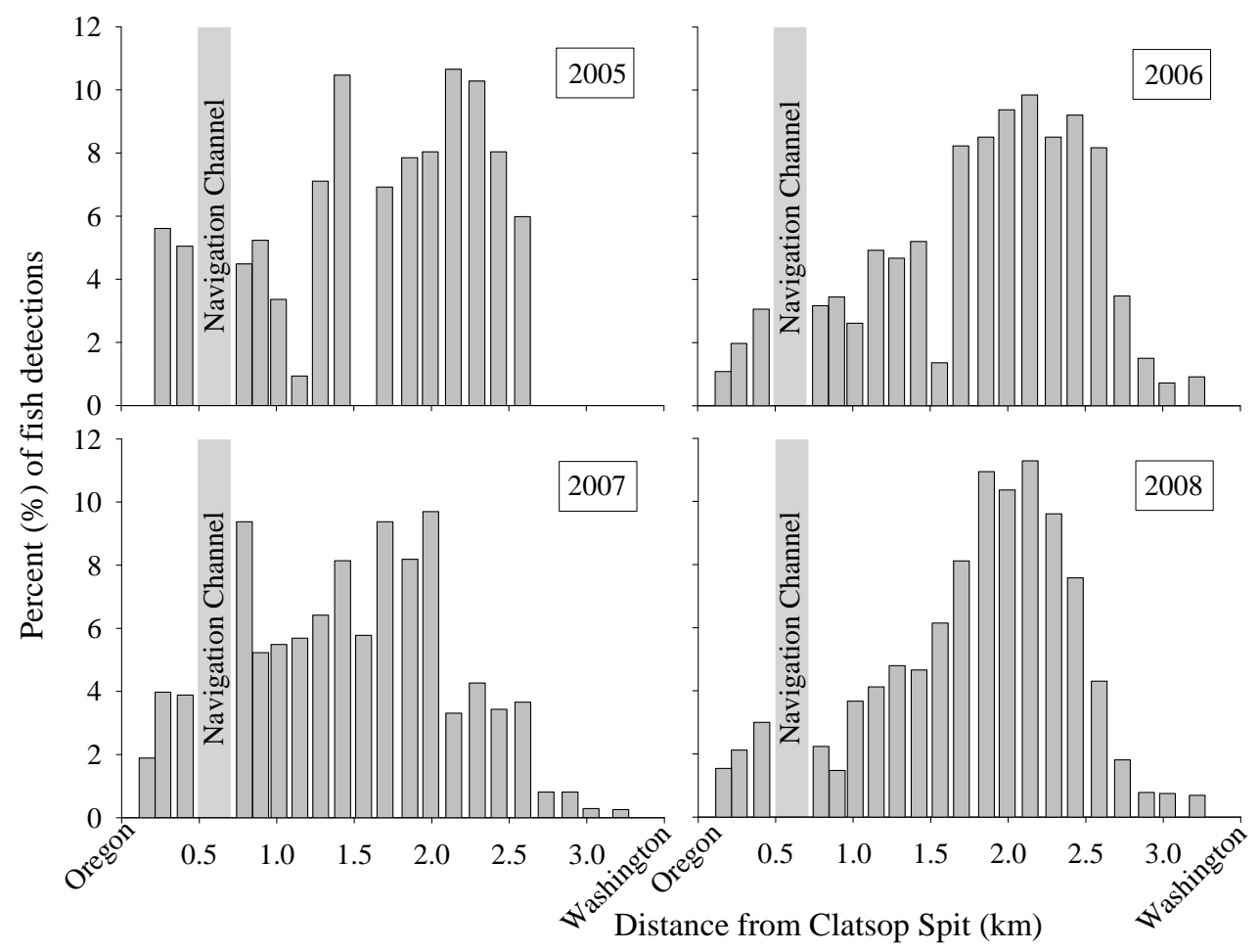

Figure 3.20. Cross-channel distribution of yearling Chinook salmon at array CR008.3. 


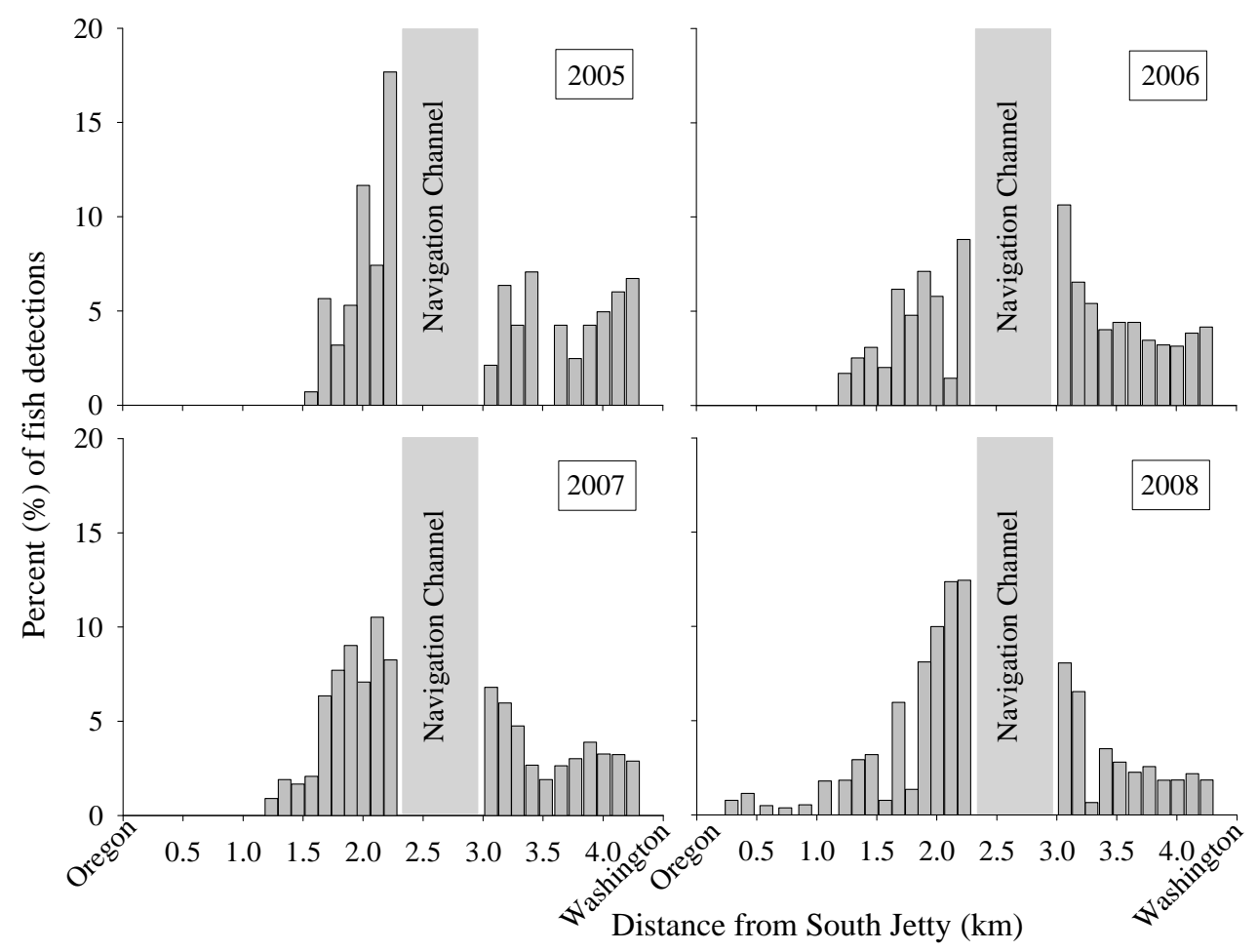

Figure 3.21. Cross-channel distribution of yearling Chinook salmon at array CR002.8.

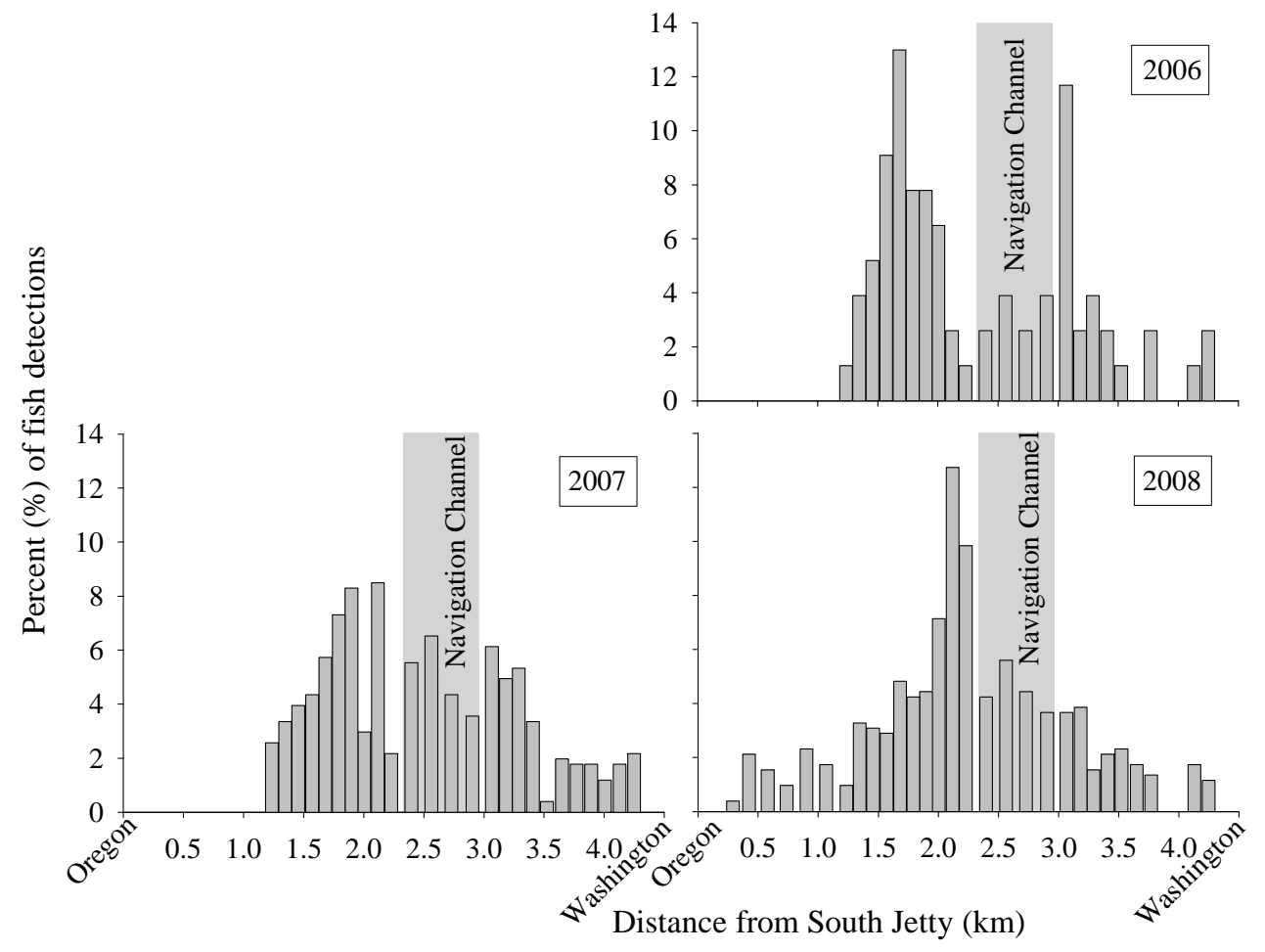

Figure 3.22. Cross-channel distribution of yearling Chinook salmon at array CR002.8 for periods during which receivers were in the navigation channel. 


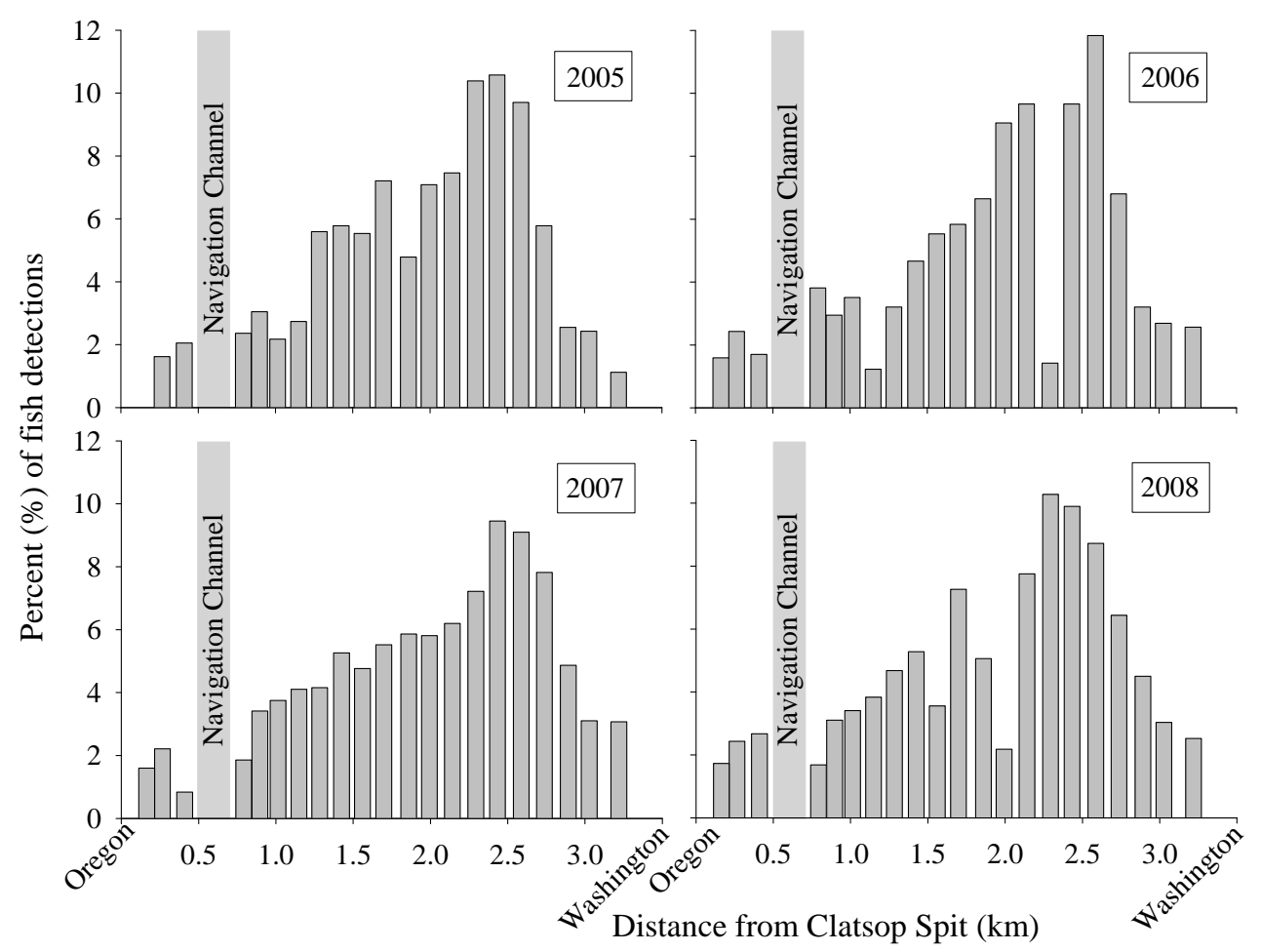

Figure 3.23. Cross-channel distribution of subyearling Chinook salmon at array CR008.3.

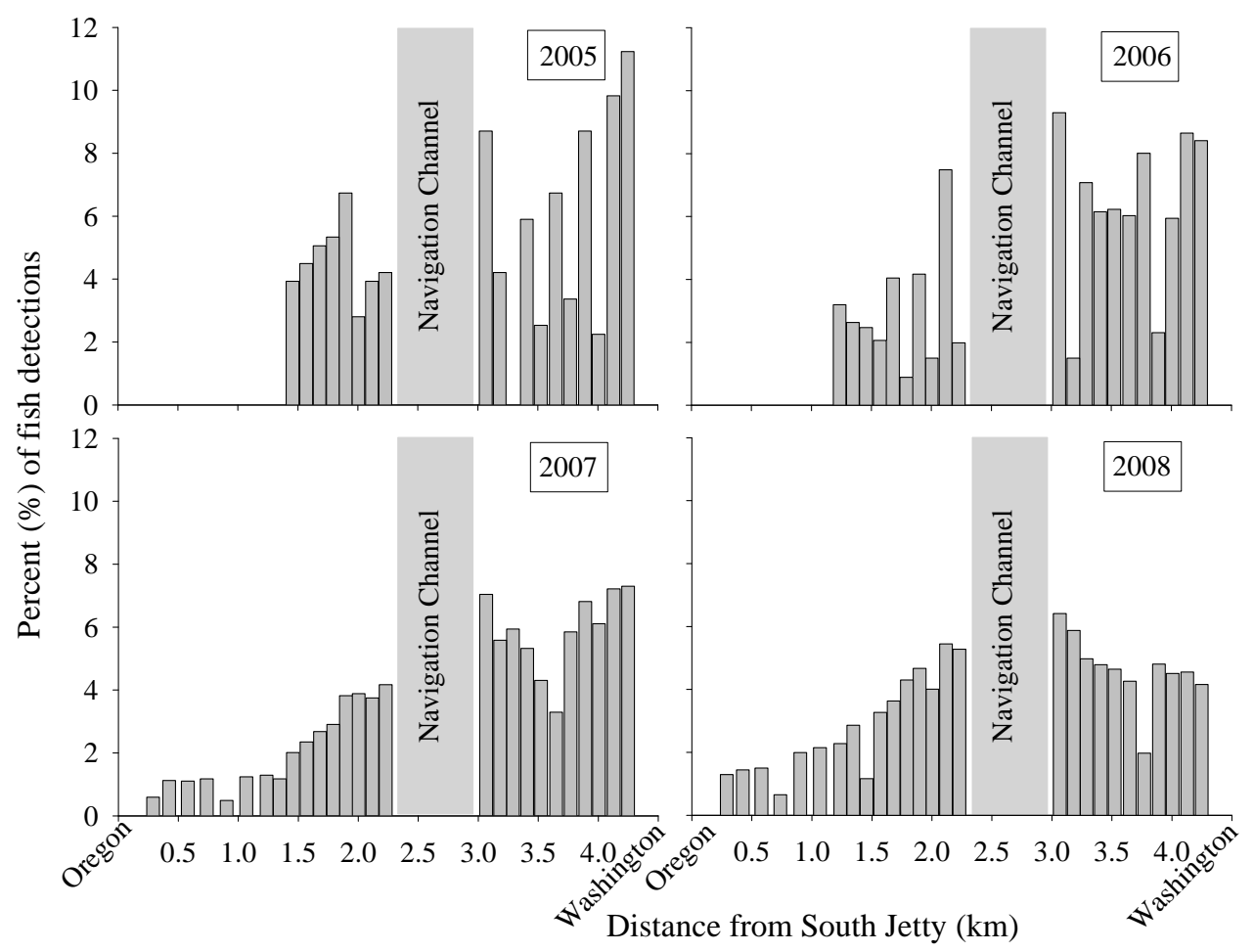

Figure 3.24. Cross-channel distribution of subyearling Chinook salmon at array CR002.8. 


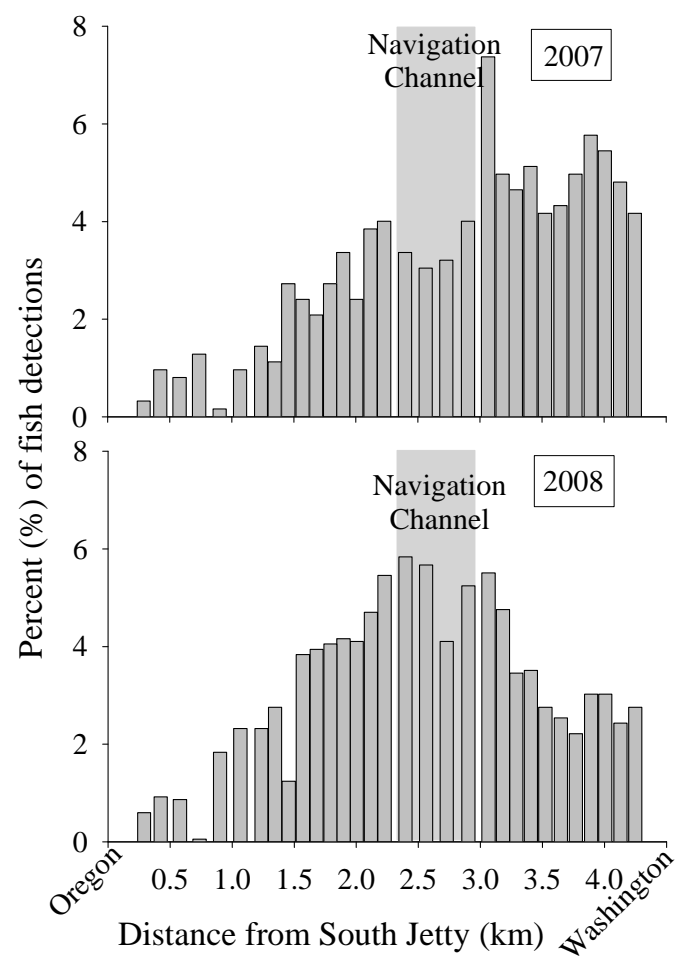

Figure 3.25. Cross-channel distribution of subyearling Chinook salmon at array CR002.8 for periods during which receivers were in the navigation channel.

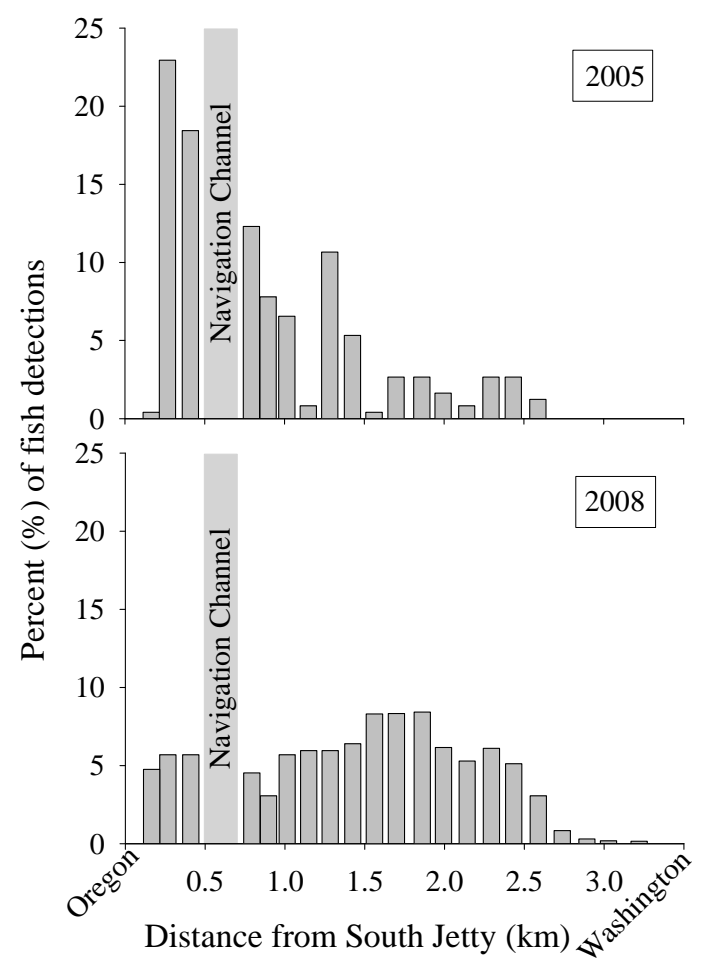

Figure 3.26. Cross-channel distribution of steelhead at array CR008.3. 


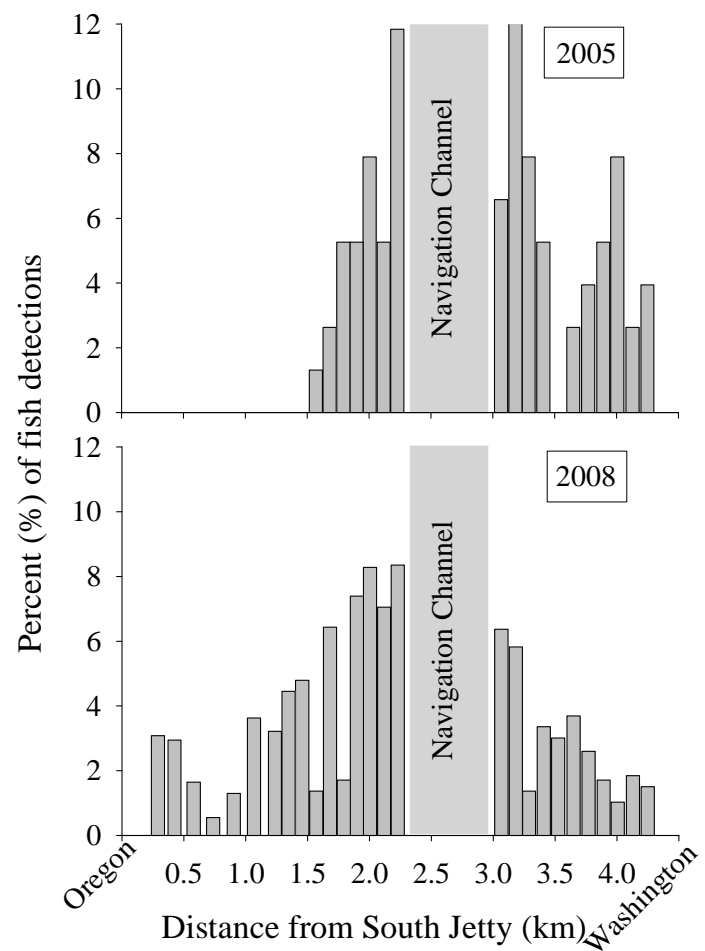

Figure 3.27. Cross-channel distribution of steelhead at array CR002.8.

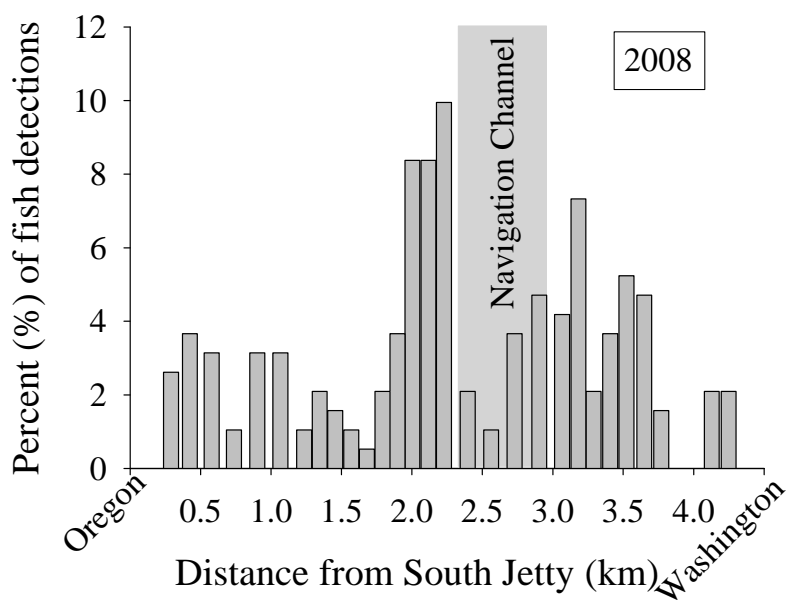

Figure 3.28. Cross-channel distribution of steelhead at array CR002.8 for periods during which receivers were in the navigation channel.

Based on detections of JSATS-tagged fish tracked in 2007, yearling Chinook salmon migrated through the lower Columbia River at shallower depths than subyearling Chinook salmon. Estimates of mean depth for yearling Chinook salmon migrating through the Lower CR ranged from $4.1 \mathrm{~m}$ to $10.5 \mathrm{~m}$. Mean depth estimates for subyearling Chinook salmon in the same section of river ranged from 4.6 to $27.7 \mathrm{~m}$. In the section of river between Vancouver and Bonneville Dam, mean depth estimates for subyearling Chinook salmon ranged from 5.7 to $14.3 \mathrm{~m}$ (Table 3.15). Depth estimates for both yearling and subyearling Chinook salmon in both sections of the river were highly variable, possibly indicating that these fish utilize a greater proportion of the available habitat than previously thought. 
Table 3.15. Estimated fish depth (m) for yearling (CH1) and subyearling (CH0) Chinook salmon tagged with JSATS acoustic transmitters in two sections of the Columbia River downstream of Bonneville Dam (data courtesy of R. L. McComas, NOAA Fisheries).

\begin{tabular}{clcccccccc}
\hline & & & \multicolumn{3}{c}{ Pings/Fish } & \multicolumn{3}{c}{ Mean depth (m) } \\
\cline { 3 - 9 } Species/Run & \multicolumn{1}{c}{} & Location & $\mathrm{N}$ & Mean & Min & Max & $\begin{array}{c}\text { Global } \\
\text { mean }\end{array}$ & $\begin{array}{c}\text { Min of } \\
\text { mean }\end{array}$ & $\begin{array}{c}\text { Max of } \\
\text { mean }\end{array}$ \\
\hline CH1 & Lower CR & 6 & 97.0 & 2 & 279 & 6.3 & 4.1 & 10.5 \\
CH0 & Lower CR & 114 & 34.7 & 1 & 453 & 11.0 & 4.6 & 27.7 \\
CH0 & Vancouver to BON & 11 & 33.8 & 2 & 163 & 8.5 & 5.7 & 14.3 \\
\hline
\end{tabular}




\subsection{Discussion}

Many species of juvenile anadromous Pacific salmon rear in or pass through the Columbia River estuary and plume, including pink salmon, chum salmon, coho salmon, coastal cutthroat trout, Chinook salmon, steelhead, sockeye salmon, and bull trout/dolly varden. Historically there was a wider diversity of life histories employed by salmonids present in the estuary and greater use of the nearshore and wetland habitats for rearing. Hatchery programs, flow regulation, and salmon population declines throughout the Columbia River basin, as well as wetland habitat losses and increasing water temperatures in the estuary, have contributed to decreased use of the estuary by juvenile salmonids in summer and fall compared to historic levels. Information on use of the Columbia River estuary by pre-smolt Chinook salmon, steelhead trout, and sockeye salmon is scarce in the literature. Chinook salmon pre-smolts used backwater habitats for rearing in the lower Columbia River estuary and near the Columbia River mouth. Pre-smolt steelhead are likely very rare in the Columbia River estuary because spawning typically occurs in high-elevation, cold-water tributaries. Additionally, sockeye salmon pre-smolts are most likely confined to high-elevation lakes closer to where breeding and rearing occurs, and juveniles use the estuary only during outmigration. Currently, the majority of juvenile salmon rearing in or passing through the Columbia River estuary are hatchery fish from upstream sources that simply migrate through the estuary as they pass from freshwater to the ocean.

The majority of juvenile salmon migration through the estuary occurs between March and October, with peaks at various times depending on species and run type. Capture studies using beach and purse seines and trawls have been conducted throughout the year at various sites in the mid to lower portion of the estuary to determine the seasonal migration patterns of juvenile salmonid species (Dawley et al. 1986; McCabe et al. 1986; Roegner et al. 2004; Bottom et al. 2008). Subyearling Chinook salmon are the most abundant salmon in the estuary, and rearing or migratory juveniles are present throughout the year. Chum salmon abundance in the estuary peaks in early to mid-May, followed by coho salmon in mid to late May, then steelhead and sockeye in late May, yearling Chinook salmon in late May and early June, and then subyearling Chinook salmon in late June and July.

Many Columbia River salmonids, such as yearling coho salmon, yearling Chinook salmon, chum salmon, and steelhead, enter the ocean during late spring and early summer when river flows are high and the low-salinity plume is well developed (De Robertis et al. 2005). Samples from trawls, seines, and net tows have found that most Columbia River yearling Chinook salmon migrate north, out of the plume area, by June (Fisher and Pearcy 1995; Van Doornik et al. 2007; Casillas et al. 2008).

Migration rates of juvenile anadromous salmonid smolts through the Columbia River estuary were highly variable, ranging from 1 to $170 \mathrm{~km} /$ day. Factors influencing migration rate include fish origin, fish size (Dawley et al. 1986), run-type (Schiewe et al. 1989), Columbia River discharge (Schreck et al. 2005, Ledgerwood et al. 2004), tidal cycle (Schreck and Stahl 1998), and diel period (Ledgerwood et al. 1991, Dawley et al. 1986; Carlson et al. 2001). In addition, JSATS data show that migration rates vary between different sections of the estuary, likely in response to channel morphology and river velocity (as influenced by tidal cycles). 
The published literature generally indicates that the majority of salmonid movement occurs during daylight hours. Studies at Jones Beach found juvenile salmonids most prevalent in catches during the morning (Dawley et al. 1986; Ledgerwood et al. 1991; Carlson et al. 2001), although Ledgerwood et al. (1991) reported no significant difference in detection rates of steelhead between day and night. JSATS fish that were tagged and released upstream of Bonneville Dam were detected nearly equally during all hours of the day. The differences in diel movements found between the seining studies and studies using JSATS may be attributable to sampling methods and/or a difference in the populations sampled. While some beach seine sampling was done at night (Dawley et al. 1986; Ledgerwood et al. 1991), the timing and amount of sampling as well as sampling gear avoidance may introduce bias in the results of these types of studies. Telemetry studies, including JSATS, are not constrained by sampling schedules, but they are typically biased toward larger fish that can accommodate an internally implanted tag. JSATS protocols based on rigorous tagging effects studies limit the size of salmonids that can be tagged to individuals $95 \mathrm{~mm}$ or longer (Hockersmith et al. 2008). The diel movement patterns of the smaller, rearing populations of salmonids in the Columbia River estuary may be more like those found in the seining and trapping studies.

Habitat use by juvenile salmonids varies depending on time of year and the size and species of fish. Capture studies have documented use of deeper offshore main channel habitats by larger yearling Chinook salmon and steelhead, whereas smaller juvenile fish, such as subyearling Chinook salmon, use the shallower water closer to shore (Dawley et al. 1986; McCabe et al. 1986; Ledgerwood et al. 1991, 2004; Johnsen and Sims 1973; Roegner et al. 2007, 2008). Smolts were also detected in side channels and bay habitats (i.e., Grays Bay) in the Columbia River estuary, albeit less commonly (Roegner et al. 2007). Telemetry studies have shown that anywhere from $5 \%$ to $44 \%$ of yearling Chinook salmon and up to $24 \%$ of steelhead used side-channel routes during their migration through the estuary (Schreck et al. 2005). Side-channel use by JSATS-tagged fish in the lower Columbia River downstream of RKM 58 ranged from $7 \%$ to $20 \%$, depending on the year and species. In the Columbia River plume, subyearling Chinook salmon appeared to be more strongly associated with shallow, nearshore areas compared to yearling Chinook salmon (Fisher and Pearcy 1995).

Juvenile salmonids are generally thought to travel through the estuary in the upper portion of the water column, although there is little specific information in the literature to confirm this. The vast majority of juvenile fall Chinook salmon in trawl samples from the channel off Tongue Point, Clatsop Spit, and Jones Beach were within $3 \mathrm{~m}$ of the surface (Dawley et al. 1986). Both laboratory and field studies have shown that juvenile salmonids prefer to occupy surface waters but will move up or down in the water column in response to adverse condition changes such as temperature and oxygen levels (Birtwell and Kruzynski 1989). The fact that steelhead and yearling Chinook salmon are more susceptible to predation by Caspian terns (Sterna caspia) than subyearling Chinook salmon may indicate they have a greater tendency to migrate near the surface of the water (Collis et al. 2001; Roby et al. 2003). Fish detected by hydroacoustics in the navigation channel and channel margins were significantly higher in the water column during the day than during the evening and night (Carlson et al. 2001). Threedimensional positioning from mobile tracking JSATS fish in the estuary indicated that yearling Chinook salmon migrate through the lower Columbia River at shallower depths than subyearling Chinook salmon—-mean migration depths are 4.1-10.5 m and 4.6-27.7 m, respectively. 
Published literature on migration behavior in the Columbia River estuary is based primarily on sampling of salmonids in different types of nets. Beach and purse seines are the most common, although some researchers have used trawls and trap nets as well (Dawley et al. 1986, McCabe et al. 1986, Bottom et al. 2008, Roegner et al. 2004, 2007, 2008). Despite potential bias from capture techniques, studies that were conducted year round have provided a general seasonal framework of the abundance and timing of outmigration of juvenile salmonids through different sections of the lower Columbia River and estuary.

Use of telemetry, including PIT, radio, and acoustic tags, to monitor juvenile salmonid movements through the lower Columbia River and estuary has been more common in the recent past (Ledgerwood et al. 1991, 2004; Schreck et al. 2005; McMichael et al. 2006). Telemetry studies have provided more detailed information on migration behavior and habitat use, although they tend to be biased toward larger fish that can accommodate an internally implanted tag.

Use of the JSATS has been limited to yearling and subyearling Chinook salmon and steelhead, all collected at Bonneville Dam or locations farther upstream. Fish size and accessibility are limiting factors, but water depth in rearing habitats is another. The JSATS autonomous receivers used between 2004 and 2008 require approximately $3 \mathrm{~m}$ of water depth in order to be deployed. Another area in which JSATS data are not currently being collected is the Columbia River plume. Development of the JSATS is ongoing, and testing of a receiver specifically designed for the challenging environment of the plume began in 2008. Development of a shallow-water receiver system also is being investigated. As technology has progressed and smaller transmitter components have become available, the size of the JSATS tag has decreased each year since the inception of the program. Development of applicationspecific tags (i.e., smaller, single-battery tags for use in smaller fish, and slightly larger, longer-life tags to be used for studying over-wintering behavior in larger fish) is now being investigated. These advancements in technology should help increase the understanding of juvenile salmonid behavior, habitat use, and survival in the Columbia River estuary and plume in the near future. 


\subsection{References}

Antolos M, DD Roby, DE Lyons, K Collis, AF Evans, M Hawbecker, and BA Ryan. 2005. Caspian tern predation on juvenile salmonids in the mid-Columbia River. Transactions of the American Fisheries Society 134:466-480.

Birtwell IK and GM Kruzynski. 1989. In situ and laboratory studies on the behaviour and survival of Pacific salmon (genus Oncorhynchus). Hydrobiologia 188/189:543-560.

Bisson PA and RE Bilby. 1982. Avoidance of suspended sediment by juvenile coho salmon. North American journal of Fisheries Management 4:371-374.

Bottom DL, CA Simenstad, J Burke, AM Baptista, DA Jay, KK Jones, E Casillas, and MH Schiewe. 2005. Salmon at River's End: The role of the Estuary in Decline and Recovery of Columbia River Salmon. NOAA Technical Memorandum NMFS-NWFSC-68, Northwest Fisheries Science Center, National Marine Fisheries Service, National Oceanic and Atmospheric Administration, Seattle, Washington.

Bottom DL, G Anderson, A Baptista, J Burke, M Burla, M Bhuthimethee, L Campbell, E Casillas, S Hinton, K Jacobson, D Jay, R McNatt, P Moran, GC Roegner, CA Simenstad, V Stamatiou, D Teel, and JE Zamon. 2008. Salmon Life Histories, Habitat, and Food Webs in the Columbia River Estuary: An Overview of Research Results, 2002-2006. Northwest Fisheries Science Center, National Marine Fisheries Service, National Oceanic and Atmospheric Administration, Seattle, Washington.

Brodeur RD, HV Lorz, and WG Pearcy. 1987. Food Habits and Dietary Variability of Pelagic Nekton off Oregon and Washington, 1979-1984. NOAA Technical Report NMFS 57, U.S. Department of Commerce, National Technical Information Service, Springfield, Virginia.

Burgner RL. 1991. Life history of sockeye salmon (Onchorhynchus nerka). In Pacific Salmon Life Histories, C Groot and L Margolis (eds), pp. 1-118. University of British Columbia Press, Vancouver, Canada.

Carlson TJ, G Ploskey, RL Johnson, RP Mueller, and MA Weiland. 2001. Observations of the Behavior and Distribution of Fish in Relation to the Columbia River Navigation Channel and Channel Maintenance Activities. PNNL-13595, Pacific Northwest National Laboratory, Richland, Washington.

Casillas E, R Brodeur, B Peterson, R Emmett, K Jacobson, D Teel, B Beckman, C Morgan, J Fisher, L Weitkamp, J Zamon, and A Baptista. 2008. Plume project - annual progress report. Document ID \#P106612, Bonneville Power Administration, Portland, Oregon. Available at http://pisces.bpa.gov/release/documents/documentviewer.aspx?doc=P106612 (April 2009).

Collis K, DD Roby, DP Craig, BA Ryan, and RD Ledgerwood. 2001. Colonial waterbird predation on juvenile salmonids tagged with passive integrated transponders in the Columbia River estuary: vulnerability of different species, stocks, and rearing types. Transactions of the American Fisheries Society 130:385-396. 
Collis K, DD Roby, DP Craig, S Adamany, JY Adkins, and DE Lyons. 2002. Colony size and diet composition of piscivorous waterbirds on the lower Columbia River: Implications for losses of juvenile salmonids to avian predation. Transactions of the American Fisheries Society 131:537-550.

Connor WP, HL Burge, R Waitt, and TC Bjornn. 2002. Juvenile life history of wild fall Chinook salmon in the Snake and Clearwater rivers. North American Journal of Fisheries Management 22:702-712.

Connor WP, JG Sneva, KF Tiffan, RK Steinhorst, and D Ross. 2005. Two alternative juvenile life history types for fall Chinook salmon in the Snake River Basin. Transactions of the American Fisheries Society 134:291-304.

Cook CB, GA McMichael, JA Vucelick, B Dibrani, EE Hockersmith, CA Duberstein, ID Welch, BJ Bellgraph, CA McKinstry, PS Titzler, DA Ogden, BP Sandford, RK Kirkham, and MD Bleich. 2007. Lower Monumental Reservoir Juvenile Fall Chinook Salmon Behavior Studies. PNWD-3800, BattellePacific Northwest Division, Richland, Washington.

Dawley EM, CW Sims, and RD Ledgerwood. 1978. A study to define the migrational characteristics of Chinook and coho salmon and steelhead trout in the Columbia River estuary. Coastal Zone and Estuarine Studies, Annual Report 1978. Northwest Fisheries Science Center, National Marine Fisheries Service, National Oceanic and Atmospheric Administration, Seattle, Washington.

Dawley EM, CW Sims, and RD Ledgerwood. 1979. A study to define the migrational characteristics of Chinook and coho salmon and steelhead trout in the Columbia River estuary. Coastal Zone and Estuarine Studies, Annual Report 1979. Northwest Fisheries Science Center, National Marine Fisheries Service, National Oceanic and Atmospheric Administration, Seattle, Washington.

Dawley EM, CW Sims, and RD Ledgerwood. 1980. A study to define the migrational characteristics of Chinook and coho salmon and steelhead trout in the Columbia River estuary. Coastal Zone and Estuarine Studies, Annual Report 1980. Northwest Fisheries Science Center, National Marine Fisheries Service, National Oceanic and Atmospheric Administration, Seattle, Washington.

Dawley EM, RD Ledgerwood, TH. Blahm, CW Sims, JT Durkin, RA Kim, AE Rankin, GE Monan, and FJ Ossiander. 1986. Migrational Characteristics, Biological Observations, and Relative Survival of Juvenile Salmonids Entering the Columbia River Estuary, 1966-1983. Northwest Fisheries Science Center, National Marine Fisheries Service, National Oceanic and Atmospheric Administration, Seattle, Washington.

De Robertis A, CA Morgan, RA Schabetsberger, RW Zabel, RD Brodeur, RL Emmett, CM Knight, GK Krutzikowsky, and E Casillas. 2005. Columbia River plume fronts. II. Distribution, abundance, and feeding ecology of juvenile salmon. Marine Ecology Progress Series 299:33-44.

Durkin JT 1982. Migration characteristics of coho salmon (Oncorhyncus kisutch) smolts in the Columbia River and its estuary. In Estuarine Comparisons, VS Kennedy (ed), pp. 365-376. Academic Press, New York. 
Dutta LK. 1976. A review of suction dredge monitoring in the lower Fraser River, 1971-1975. In Proceedings of WODCON VII, pp. 301-319. World Dredging Conference 1976, San Francisco, California.

Emmett RL, GK Krutzikowsky, and P Bentley. 2006. Abundance and distribution of pelagic piscivorous fishes in the Columbia River plume during spring/early summer 1998-2003: Relationship to oceanographic conditions, forage fishes, and juvenile salmonids. Progress in Oceanography 68:1-26.

Endangered Species Act of 1973 (16 U.S.C. 1531-1544, 87 Stat. 884), as amended - Public Law 93-205, approved December 28, 1973.

Fish Passage Center. 2008. Online database of current and historical fish passage data for the Federal Columbia River Power System. Fish Passage Center, Portland, Oregon. Available at http://www.fpc.org (April 2009).

Fisher JP and WG Pearcy. 1995. Distribution, migration, and growth of juvenile Chinook salmon Oncorhynchus tshawytscha, off Oregon and Washington. Fishery Bulletin 93:274-289.

Fresh KL, E Casillas, LL Johnson, and DL Bottom. 2005. Role of the Estuary in the Recovery of Columbia River Basin Salmon and Steelhead: An Evaluation of the Effects of Selected Factors on Salmonid Population Viability. NOAA Technical Memorandum NMFS-NWFSC-69, Northwest Fisheries Science Center, National Marine Fisheries Service, Seattle, Washington. Available at http://www.nwfsc.noaa.gov/assets/25/6286_09262005_142538_EstuaryTM69WebFinal.pdf (April 2009).

Fukuwaka M and T Suzuki. 1998. Role of a riverine plume as a nursery area for chum salmon Oncorhynchus keta. Marine Ecology Progress Series 173:289-297.

Gustafson RG, TC Wainwright, GA Winas, FW Waknitz, LT Parker, and RS Waples. 1997. Status Review of Sockeye Salmon from Washington and Oregon. NOAA Technical Memorandum NMFSNWFSC-33, Northwest Fisheries Science Center, National Marine Fisheries Service, Seattle, Washington.

Hard JJ, RG Kope, WS Grant, FW Waknitz, LT Parker, and RS Waples. 1996. Status Review of Pink Salmon from Washington, Oregon, and California. NOAA Technical Memorandum NMFS-NWFSC-25, Northwest Fisheries Science Center, National Marine Fisheries Service, Seattle, Washington.

Healy MC. 1991. Life history of Chinook salmon (Oncorhyncus tshawytscha). In Pacific Salmon Life Histories, C Groot and L Margolis (eds), pp. 311-394. University of British Columbia Press, Vancouver, Canada.

Healy MC. 1982. Juvenile Pacific salmon in estuaries: The life support system. In Estuarine Comparisons, VS Kennedy (ed), pp. 315-341. Academic Press, New York.

Hickey BM and NS Banas. 2003. Oceanography of the U.S. Pacific Northwest coastal ocean and estuaries with application to coastal ecology. Estuaries 26:1010-1031.

Hinton SA and RL Emmett. 1994. Juvenile Salmonid Stranding in the Lower Columbia River, 1992 and 1993. NOAA Technical Memorandum NMFS-NWFSC-20, Northwest Fisheries Science Center, 
National Marine Fisheries Service, Seattle, Washington. Available at http://www.nwfsc.noaa.gov/publications/techmemos/tm20/stranding.html (April 2009).

Hockersmith EE, RS Brown, and TL Liedtke. 2008. Comparative Performance of Acoustic-Tagged and Passive Integrated Transponder-Tagged Juvenile Salmonids. U.S. Army Corps of Engineers, Portland District, Portland, Oregon. Available at https://www.nwp.usace.army.mil/pm/e/afep_system.asp (April 2009).

Huyer A. 1983. Coastal upwelling in the California current. Progressive Oceanographer 12:259-284.

Johnsen RC and CW Sims. 1973. Purse seining for juvenile salmon and trout in the Columbia River estuary. Transactions of the American Fisheries Society 102:341-345.

Johnson GE, BD Ebberts, RM Thom, NM Ricci, AH Whiting, JA Southard, GB Southerland, JD Wilcox, T Berquam. 2003. An Ecosystem-Based Approach to Habitat Restoration Projects with Emphasis on Salmonids in the Columbia River Estuary. PNNL-14412, Pacific Northwest National Laboratory, Richland, Washington.

Johnson JR, J Zydlewski, G Zydlewski, J Hogle, J Brunzell, and JM Hudson. 2008. Coastal Cutthroat Trout Migration Patterns in Lower Columbia River Tributaries. In Movements of Coastal Cutthroat Trout (Oncorhynchus clarki clarki) in theLlower Columbia River: Tributary, Mainstem and Estuary Use. U.S. Fish and Wildlife Service, Columbia River Fisheries Program Office, Vancouver, Washington.

Johnson OW, WS Grant, RG Kope, K Neely, FW Waknitz, and RS Waples. 1997. Status Review of Chum Salmon from Washington, Oregon, and California. NOAA Technical Memorandum NMFSNWFSC-32, Northwest Fisheries Science Center, National Marine Fisheries Service, Seattle, Washington.

Kehoe DM. 1983. Effects of Grays Harbor estuary sediment on the osmoregulatory ability of coho salmon smolts (Oncorhynchus kisutch). Bulletin of Environmental Contamination and Toxicology 30:522-529.

Kundu PK and JS Allen. 1976. Some three-dimensional characteristics of low-frequency fluctuations near the Oregon coast. Journal of Physical Oceanography 6:181-199.

Ledgerwood RD, FP Thrower, and EM Dawley. 1991. Diel sampling of migratory juvenile salmonids in the Columbia River estuary. Fishery Bulletin 88:69-78.

Ledgerwood RD, SW Naman, BA Ryan, BP Sandford, CZ Banks, and JW Ferguson. 2004. Detection of PIT-Tagged Juvenile Salmonids in the Columbia River Estuary Using a Pair-Trawl, 2000 and 2001. Contract Report 4328, Northwest Fisheries Science Center, National Marine Fisheries Service, Seattle, Washington. Available at http://www.nwfsc.noaa.gov/publications/displayallinfo.cfm?docmetadataid=4328 (April 2009).

Levy DA and TG Northcote. 1982. Juvenile salmon residency in a marsh area of the Fraser River estuary. Canadian Journal of Fisheries and Aquatic Sciences 39:270-276. 
Loch, JJ. 1982. Juvenile and Adult Steelhead and Sea-Run Cutthroat Trout within the Columbia River Estuary, 1980. Fisheries Research Report 82-2, Washington Department of Game, Olympia.

Loch JJ and DR Miller. 1988. Distribution and diet of sea-run cutthroat trout captured in and adjacent to the Columbia River plume, May-July 1980. Northwest Science 62:41-48.

Lower Columbia Fish Recovery Board. 2004. Volume II - Subbasin Plan, Chapter A - Lower Columbia Mainstem and Estuary. In Lower Columbia Salmon Recovery and Fish \& Wildlife Subbasin Plan.

Northwest Power and Conservation Council, Portland, Oregon. Available at http://www.nwcouncil.org/fw/subbasinplanning/lowerColumbia/plan/ (April 2009).

Marsh DM, JR Harmon, NN Paasch, KL Thomas, KW McIntyre, WD Muir, and WP Connor. 2007. A Study To Understand the Early Life History of Snake River Basin Fall Chinook Salmon. Northwest Fisheries Science Center, National Marine Fisheries Service, Seattle, Washington.

McCabe GT Jr, RL Emmett, WD Muir, and TH Blahm. 1986. Utilization of the Columbia River estuary by subyearling Chinook salmon. Northwest Science 60:113-124.

McComas RL, D Frost, SG Smith, and JW Ferguson. 2005. A Study to Estimate Juvenile Salmonid Survival through the Columbia River Estuary Using Acoustic Tags, 2002. Northwest Fisheries Science Center, National Marine Fisheries Service, Seattle, Washington.

McComas RL, L Gilbreath, SG Smith, GMMatthews, JW Ferguson, GA McMichael, JA Vucelick, and TJ Carlson. 2005. A Study to Estimate Juvenile Salmonid Survival through the Columbia River Estuary Using Acoustic Tags, 2005. U.S. Army Corps of Engineers, Portland District, Portland, Oregon. Available at https://www.nwp.usace.army.mil/pm/e/afep_estuary.asp (April 2009).

McComas RL GA McMichael, JA Vucelick, L Gilbreath, JP Everett, SG Smith, T Carlson, G Matthews, and JW Ferguson. 2008. A Study to Estimate Salmonid Survival through the Columbia River Estuary Using Acoustic Tags, 2006. U.S. Army Corps of Engineers, Portland District, Portland, Oregon. Available at https://www.nwp.usace.army.mil/pm/e/afep_estuary.asp (April 2009).

McMichael GA, JA Vucelick, BA Ryan, L Gilbreath, RL McComas, D Elliott, T Murray, L Applegate, and C McKibben. 2006a. Alternative Barging Strategies to Improve Survival of Transported Juvenile Salmonids - 2005. PNWD-3702, Battelle-Pacific Northwest Division, Richland, Washington.

McMichael GA, GE Johnson, JA Vucelick, GR Ploskey, and TJ Carlson. 2006b. Use of Acoustic Telemetry to Assess Habitat Use of Juvenile Chinook Salmon and Steelhead at the Mouth of the Columbia River. PNNL-15575, Pacific Northwest National Laboratory, Richland, Washington.

McMichael GA, MC Richmond, WA Perkins, JR Skalski, RA Buchanan, JA Vucelick, EE Hockersmith, BR Beckman, PN Westhagen, KD Ham, ID Welch, BJ Bellgraph, PS Titzler, and BP Sandford. 2008. Lower Monumental Reservoir Juvenile Fall Chinook Salmon Behavior Studies, 2007. PNWD-3959, Battelle-Pacific Northwest Division, Richland, Washington.

McMichael GA, MB Eppard, TJ Carlson, JA Carter, BD Ebberts, RS Brown, M Weiland, GR Ploskey, RA Harnish, and ZD Deng. Development of a new tool to investigate juvenile salmon movement and survival: The Juvenile Salmon Acoustic Telemetry System (JSATS). Fisheries (in review). 
Myers KW and HF Horton. 1982. Temporal use of an Oregon estuary by hatchery and wild juvenile salmon. In Estuarine Comparisons, VS Kennedy (ed), pp. 377-392. Academic Press, New York.

NMFS (National Marine Fisheries Service). 2005. Endangered Species Act - Section 7, Consultation Biological Opinion and Conference Option \& Magnuson-Stevens Fishery Conservation and Management Act Essential Fish Habitat Consultation for the U.S. Army Corps of Engineers Columbia River Channel Operations and Maintenance Program, Mouth of the Columbia River to Bonneville Dam. NMFS Tracking No. 2004/01041, Northwest Fisheries Science Center, National Marine Fisheries Service, Seattle, Washington.

NMFS (National Marine Fisheries Service). 2006. Final draft Columbia River estuary recovery plan module. Prepared by the Lower Columbia River Estuary Partnership under contract to NOAA Fisheries.

Pearcy WG and JP Fisher. 1988. Migrations of coho salmon, Oncorhynchus kisutch, during their first summer in the ocean. Fisheries Bulletin 86:173-195.

Pearson W, N Kohn, and G Williams. 2005. Approach to Estimation of Entrainment of Coho Salmon by Dredges in Washington and Oregon. PNNL-15287, Pacific Northwest National Laboratory, Richland, Washington.

Pearson WH, JR Skalski, KL Sobocinski, MC Miller, GE Johnson, GD Williams, JA Southard, and RA Buchanan. 2006. A Study of Stranding of Juvenile Salmon by Ship Wakes Along the Lower Columbia River Using a Before-and-After Design: Before-Phase Results. PNNL-15400, Pacific Northwest National Laboratory, Richland, Washington.

Ploskey GR, MA Weiland, JS Hughes, SR Zimmerman, RE Durham, ES Fischer, J Kim, RL Townsend, JR Skalski, and RL McComas. 2007. Acoustic Telemetry Studies of Juvenile Chinook Salmon Survival at the Lower Columbia Projects in 2006. PNNL-16560, Pacific Northwest National Laboratory, Richland, Washington. Available at https://www.nwp.usace.army.mil/pm/e/afep_bon.asp (April 2009).

Quinn TP. 2005. The Behavior and Ecology of Pacific Salmon and Trout. University of Washington Press, Seattle.

Rich WH. 1920. Early History and Seaward Migration of Chinook Salmon in the Columbia and Sacramento Rivers. Bulletin of the U.S. Bureau of Fisheries 37:1-74.

Roby DD, DE Lyons, DP Craig, K Collis, and GH Visser. 2003. Quantifying the effect of predators on endangered species using a bioenergetis approach: Caspian terns and juvenile salmonids in the Columbia River estuary. Canadian Journal of Zoology 81:250-265.

Roby DD, K Collis, and DE Lyons. 2005. Conservation and Management for Fish-Eating Birds and Endangered Salmon. General Technical Report PSW-GTR-191, USDA Forest Service, Albany, California.

Roegner GC, DL Bottom, A Baptista, S Hinton, CA Simenstad, E Casillas, and K Jones. 2004. Estuarine Habitat and Juvenile Salmon - Current and Historical Linkages in the Lower Columbia River and Estuary, 2003. Northwest Fisheries Science Center, National Marine Fisheries Service, Seattle, Washington. 
Roegner GC, EM Dawley, AH Whiting, and BD Ebberts. 2007. Monitoring juvenile salmon use and fish community structure in restored wetland habitat. Chapter 7 in Evaluating Cumulative Ecosystem Response to Restoration Projects in the Columbia River Estuary, Annual Report 2006, G Johnson (ed), pp. 7.1-7.7. PNNL-16561, Pacific Northwest National Laboratory, Richland, Washington.

Roegner GC, AH Whiting, M Russell, EM Dawley, and BD Ebberts. 2008. Response by juvenile salmon to newly restored tidal wetland habitats in the lower Columbia River. Appendix F in Evaluating Cumulative Ecosystem Response to Restoration Projects in the Columbia River Estuary, Annual Report 2007GE Johnson and HL Diefenderfer (eds), pp. F.1-F.20. PNNL-17437, Pacific Northwest National Laboratory, Richland, Washington.

Schiewe MH, DM Miller, EM Dawley, RD Ledgerwood, and RL Emmett. 1989. Quality and Behavior of Jjuvenile Salmonids in the Columbia River Estuary and Nearshore Ocean. Northwest Fisheries Science Center, National Marine Fisheries Service, Seattle, Washington.

Salo EO. 1991. Life history of chum salmon (Onchorhynchus keta). In Pacific Salmon Life Histories, C Groot and L Margolis, pp. 231-310. University of British Columbia Press, Vancouver, Canada.

Sandercock FK. 1991. Life history of coho salmon (Onchorhyncus kisutch). In Pacific Salmon Life Histories, C Groot and L Margolis, pp. 395-446. University of British Columbia Press, Vancouver, Canada.

Schreck CB and TP Stahl. 1998. Evaluation of Migration and Survival of Juvenile Salmonids Following Transportation. Oregon Cooperative Fishery Unit, Department of Fisheries and Wildlife, Oregon State University, Corvallis.

Schreck CB, MD Karnowski, and BJ Clemens. 2005. Evaluation of Post Release Losses and Barging Strategies that Minimize Post Release Mortality. Oregon Cooperative Fishery Unit, Department of Fisheries and Wildlife, Oregon State University, Corvallis.

Sigler JW, TC Bjornn, and FH Everest. 1984. Effects of chronic turbidity on density and growth of steelheads and Coho salmon. Transactions of the American Fisheries Society 113:142-150.

Simenstad CA, KI Fresh, and EO Salo. 1982. The role of Puget Sound and Washington coastal estuaries in the life history of Pacific salmon: An unappreciated function. In Estuarine Comparisons, VS Kennedy (ed), pp. 343-364. Academic Press, New York.

Thorpe JE. 1994. Salmonid fishes and the estuarine environment. Estuaries. 17(1A):76-93.

Trotter PC. 1989. Coastal cutthroat trout: a life history compendium. Transactions of the American Fisheries Society 118:463-473.

Van Doornik D M, DJ Teel, DR Kuligowski, CA Morgan, and E Casillas. 2007. Genetic analyses provide insight into the early ocean stock distribution and survival of juvenile coho salmon off the coasts of Washington and Oregon. North American Journal of Fisheries Management 27:220-237. 
Williams GD, WH Pearson, NR Evans, and MG Anderson. 2004. Benson Beach Demonstration Project: Composition and Abundance of Biota at Three Alternative Sump Sites. PNNL-14522, Pacific Northwest National Laboratory, Richland, Washington.

Zydlewski J, JR Johnson, J Hogle, J Brunzell, S Clements, M Karnowski, and C. Shreck. 2008. Seaward migration of coastal cutthroat trout (Oncorhynchus clarki clarki) from four tributaries of the Columbia River. In Movements of Coastal Cutthroat Trout (Oncorhynchus clarki clarki) in the Lower Columbia River: Tributary, Mainstem and Estuary Use. U.S. Fish and Wildlife Service, Columbia River Fisheries Program Office, Vancouver, Washington. Insert appendix: 


\section{Appendix}

\section{Latitudes and Longitudes for Receiver Locations and Reference Points}


Table A.1. Receiver CR002.8

\begin{tabular}{|c|c|c|c|}
\hline & \multicolumn{3}{|c|}{ Receiver Location } \\
\hline & Latitude & Longitude & $\begin{array}{l}\text { Distance from } \\
\text { South Jetty (km) }\end{array}$ \\
\hline South Jetty Reference Point & 46.2333 & -124.0616 & -- \\
\hline CR002.8_01 & 46.2711 & -124.0706 & 4.25 \\
\hline CR002.8_02 & 46.2701 & -124.0698 & 4.13 \\
\hline CR002.8_03 & 46.2690 & -124.0690 & 4.01 \\
\hline CR002.8_04 & 46.2681 & -124.0682 & 3.89 \\
\hline CR002.8_05 & 46.2670 & -124.0674 & 3.77 \\
\hline CR002.8_06 & 46.2660 & -124.0667 & 3.65 \\
\hline CR002.8_07 & 46.2649 & -124.0658 & 3.52 \\
\hline CR002.8_08 & 46.2639 & -124.0650 & 3.41 \\
\hline CR002.8_09 & 46.2629 & -124.0642 & 3.29 \\
\hline CR002.8_10 & 46.2620 & -124.0634 & 3.18 \\
\hline CR002.8_11 & 46.2609 & -124.0627 & 3.07 \\
\hline CR002.8_12 & 46.2595 & -124.0622 & 2.90 \\
\hline CR002.8_13 & 46.2579 & -124.0618 & 2.73 \\
\hline CR002.8_14 & 46.2564 & -124.0614 & 2.56 \\
\hline CR002.8_15 & 46.2549 & -124.0610 & 2.40 \\
\hline CR002.8_16 & 46.2534 & -124.0605 & 2.23 \\
\hline CR002.8_17 & 46.2524 & -124.0603 & 2.12 \\
\hline CR002.8_18 & 46.2513 & -124.0601 & 2.00 \\
\hline CR002.8_19 & 46.2504 & -124.0600 & 1.90 \\
\hline CR002.8_20 & 46.2494 & -124.0598 & 1.79 \\
\hline CR002.8_21 & 46.2484 & -124.0598 & 1.68 \\
\hline CR002.8_22 & 46.2474 & -124.0597 & 1.57 \\
\hline CR002.8_23 & 46.2464 & -124.0597 & 1.46 \\
\hline CR002.8_24 & 46.2454 & -124.0597 & 1.35 \\
\hline CR002.8_25 & 46.2444 & -124.0596 & 1.24 \\
\hline CR002.8_26 & 46.2429 & -124.0602 & 1.07 \\
\hline CR002.8_27 & 46.2415 & -124.0609 & 0.90 \\
\hline CR002.8_28 & 46.2400 & -124.0615 & 0.74 \\
\hline CR002.8_29 & 46.2385 & -124.0623 & 0.58 \\
\hline CR002.8_30 & 46.2371 & -124.0629 & 0.42 \\
\hline CR002.8_31 & 46.2356 & -124.0636 & 0.29 \\
\hline
\end{tabular}


Table A.2. Receiver CR008.3

\begin{tabular}{|c|c|c|c|c|c|c|}
\hline \multirow[b]{2}{*}{ Receiver } & \multicolumn{3}{|c|}{ Receiver Location } & \multicolumn{3}{|c|}{ Corresponding 2005 Receiver Locations } \\
\hline & Latitude & Longitude & $\begin{array}{l}\text { Distance from } \\
\text { Clatsop Spit (km) }\end{array}$ & Receiver & Latitude & Longitude \\
\hline $\begin{array}{l}\text { Clatsop Spit } \\
\text { Reference Point }\end{array}$ & 46.2354 & -123.9993 & -- & -- & -- & -- \\
\hline CR008.3_24 & 46.2352 & -123.9972 & 0.16 & -- & -- & -- \\
\hline CR008.3_23 & 46.2364 & -123.9962 & 0.27 & -- & -- & -- \\
\hline CR008.3_22 & 46.2376 & -123.9951 & 0.41 & -- & -- & -- \\
\hline CR008.3_19 & 46.2404 & -123.9920 & 0.79 & WA1-15 & 46.2403 & -123.9930 \\
\hline CR008.3_18 & 46.2412 & -123.9937 & 0.79 & WA1-14 & 46.2414 & -123.9924 \\
\hline CR008.3_17 & 46.2426 & -123.9941 & 0.90 & WA1-13 & 46.2424 & -123.9916 \\
\hline CR008.3_16 & 46.2439 & -123.9946 & 1.01 & WA1-12 & 46.2436 & -123.9909 \\
\hline CR008.3_15 & 46.2452 & -123.9949 & 1.15 & WA1-11 & 46.2446 & -123.9900 \\
\hline CR008.3_14 & 46.2466 & -123.9953 & 1.28 & WA1-10 & 46.2457 & -123.9892 \\
\hline CR008.3_13 & 46.2479 & -123.9957 & 1.43 & WA1-09 & 46.2470 & -123.9885 \\
\hline CR008.3_12 & 46.2492 & -123.9962 & 1.56 & WA1-08 & 46.2480 & -123.9877 \\
\hline CR008.3_11 & 46.2505 & -123.9966 & 1.70 & WA1-07 & 46.2491 & -123.9868 \\
\hline CR008.3_10 & 46.2520 & -123.9971 & 1.86 & WA1-06 & 46.2502 & -123.9862 \\
\hline CR008.3_09 & 46.2532 & -123.9975 & 1.99 & WA1-05 & 46.2512 & -123.9857 \\
\hline CR008.3_08 & 46.2546 & -123.9978 & 2.14 & WA1-04 & 46.2524 & -123.9848 \\
\hline CR008.3_07 & 46.2560 & -123.9983 & 2.29 & WA1-03 & 46.2533 & -123.9840 \\
\hline CR008.3_06 & 46.2572 & -123.9986 & 2.43 & WA1-02 & 46.2545 & -123.9833 \\
\hline CR008.3_05 & 46.2586 & -123.9991 & 2.59 & WA1-01 & 46.2555 & -123.9827 \\
\hline CR008.3_04 & 46.2600 & -123.9995 & 2.74 & -- & -- & -- \\
\hline CR008.3_03 & 46.2614 & -123.9999 & 2.89 & -- & -- & -- \\
\hline CR008.3_02 & 46.2626 & -124.0005 & 3.03 & -- & -- & -- \\
\hline CR008.3_01 & 46.2643 & -124.0009 & 3.22 & -- & -- & -- \\
\hline
\end{tabular}




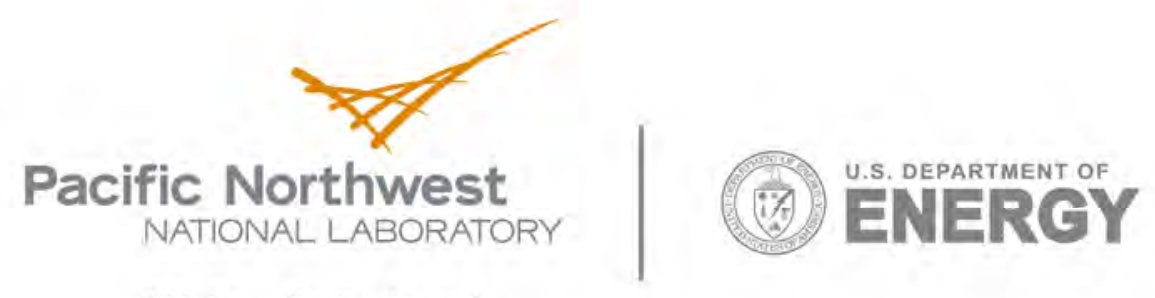

902 Battelle Boulevard

P.O. Box 999

Richland, WA 99352

1-888-375-PNNL (7665)

www.pnl.gov 